\title{
دراسة أثرية فنية لثلاثة دلاء برونزية محفوظة بمتحف الفن الإسلامي بالقاهرة
}

\author{
(تنشر لأول مرة)
}

\section{An Archaeological and Artistic Study of Three Bronze Buckets in the Museum of Islamic Art in Cairo (Publication for the First Time)}

\author{
أيمن مصطقى إدريس \\ أستاذ مساعد قسم الآثار الإسلامية- كلية الآثار - جامعة الفيوم
}

\section{Ayman Mustafa Edris}

Assistant prof. of Department of Islamic Archaeology, Faculty of Archaeology, Fayoum University ame00@fayoum.edu.eg

الملخص:

تهـدف هذه الورقـة البحثبـة إلى دراسـة مجموعـة مـن الدلاء المعدنيـة، مصنوعة مـن البرونز، محفوظـة بمتحف الفن

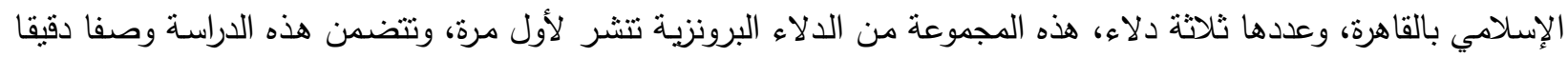

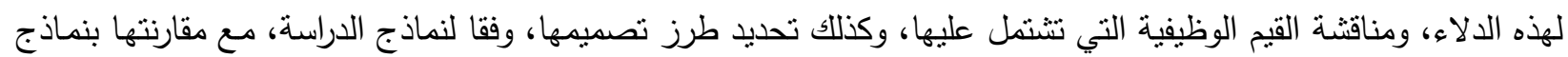

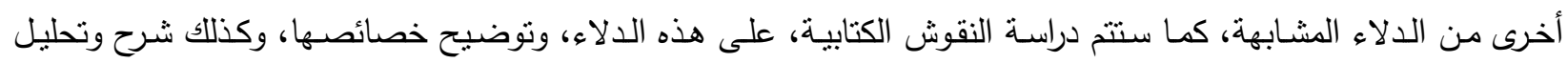

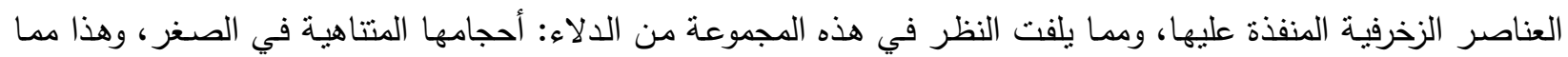
يدعو إلى محاولة إعادة النظر في استخداماتها الفعلية، في ضوء ما يتوفر من أدلة، وقرائن، وبراهين؛ وذلك من أجل وضع هنع

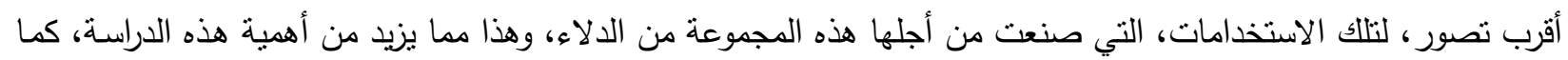
سيتم تأريخ هذه المجموعة من الدلاء، وتحديد مكان صناعتها.

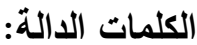
دلو ؛ برونز ؛ فنون؛ فاطمي؛ إسلامي.

\section{Abstract:}

This paper aims to study three metal buckets, made of bronze, from the Museum of Islamic art in Cairo, these three bronze buckets will be published for the first time. The study includes a description of these buckets, an explanation of the functional values and classification of their design styles. This study, also, includes an analysis of the inscriptions and decorative elements of these buckets. The noticeable thing is the very small sizes of these buckets; this topic leads us to reconsider the actual usages of these buckets, in order to get a closer idea of those usages; which these buckets were made for; this topic increases the importance of this study. This study will date these buckets and determine the provenance of them.

\section{Keywords:}

Bucket, Bronze, Arts, Fatimid, Islamic. 
المقدمة:

الدلو هو أحد أنواع الأوعية، المستخدمة في الحياة اليومية، ويؤدي دورا هاما، في جلب ونقل المياة، ويعرف الدلو 'بأنه: الوعاء، الذي يخرج بـه المـاء؛ من البئر، وغيرهـا'، ويستخدم في نقل الأثياء، مثل:

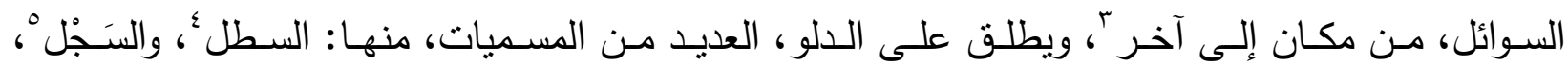

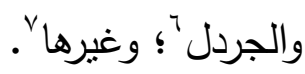

ويحتفظ متحف الفن الإسـلامي بالقـاهرة، بثلاثـة دلاء معدنيـة (غير منشـورة)، تحمـل أرقـام سـجل

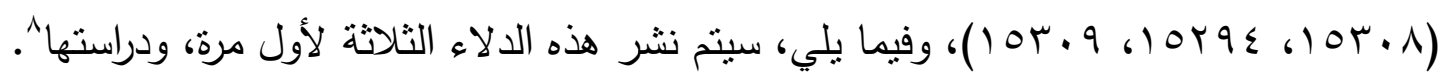

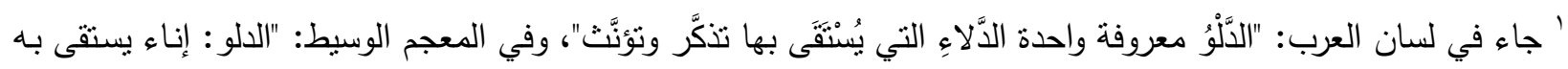

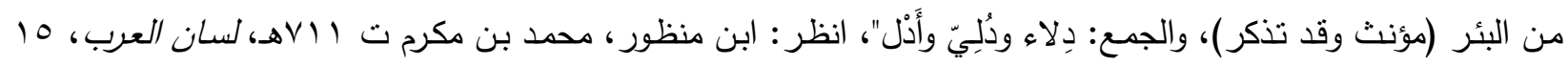

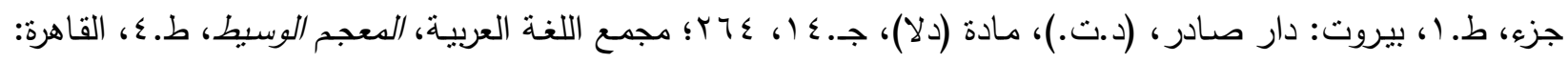

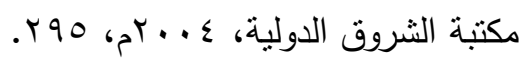

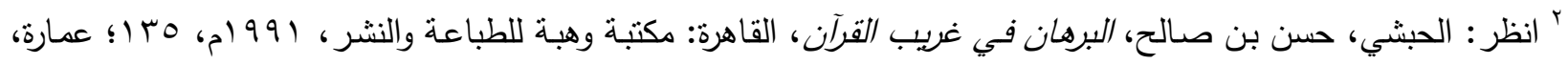

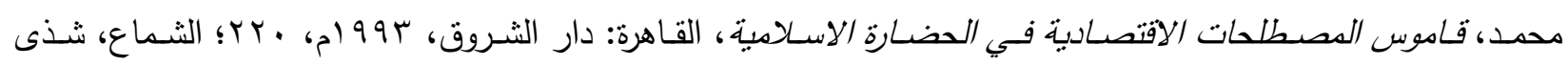

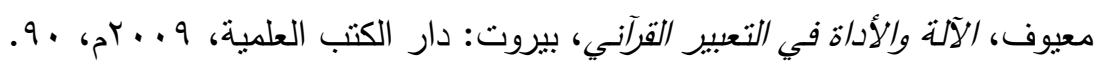
ك

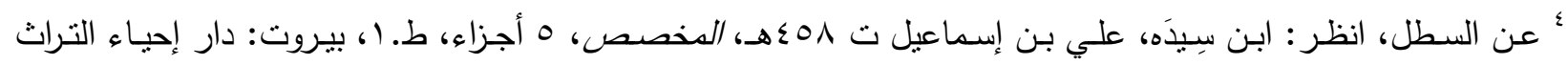

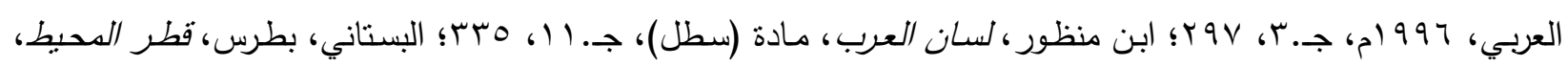

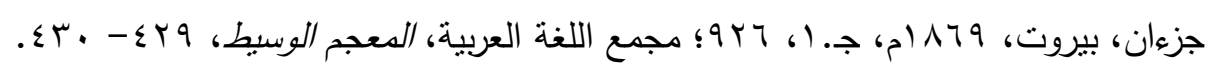

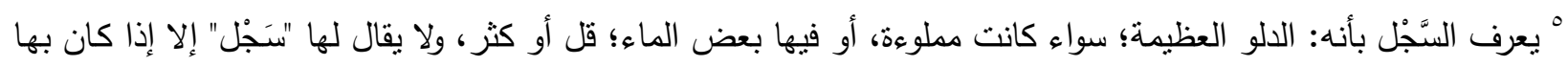

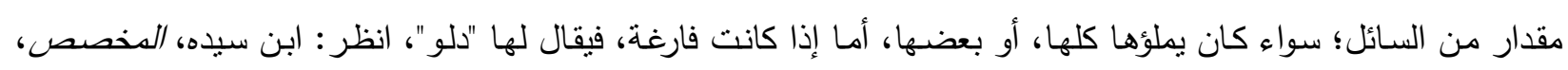

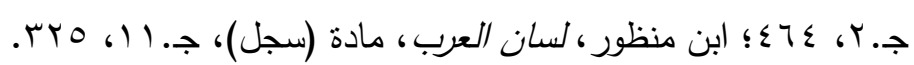

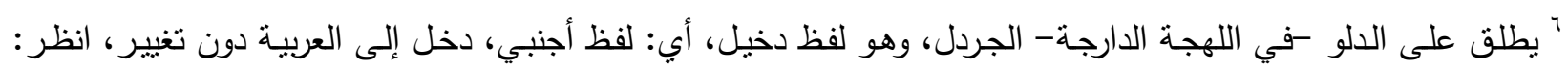

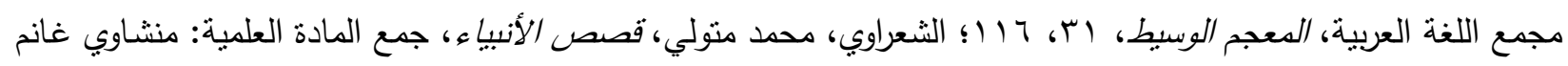

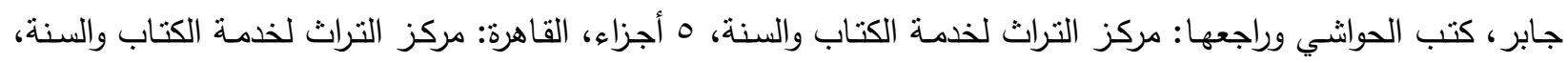

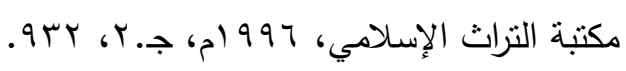

" سأعتد -في هذه الدراسة- لفظ "الدلو"، وجمعه "الدلاء"، في تسمية المجموعة (موضوع الدراسة).

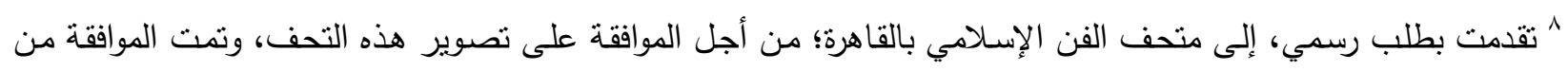

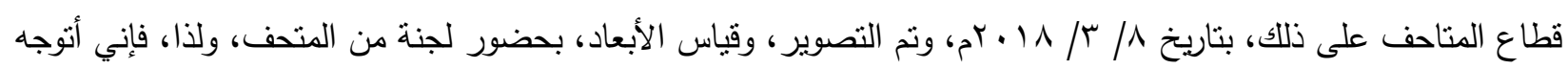

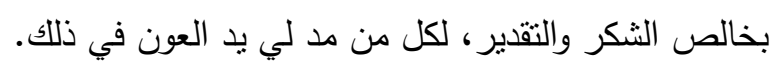




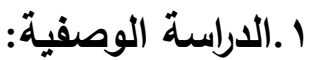

1, ا.التحفة الأولى: (لوحات 1- 1ـ؛ أثكال (، ـ أ، ب، 0، 9 أ، ب).

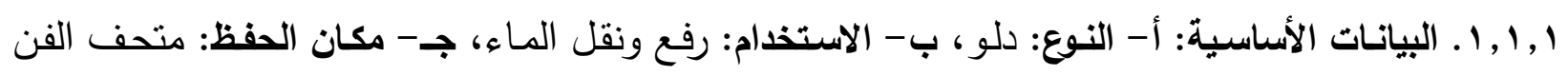

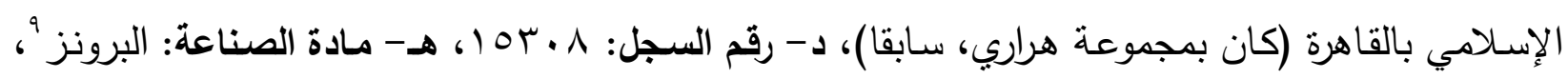

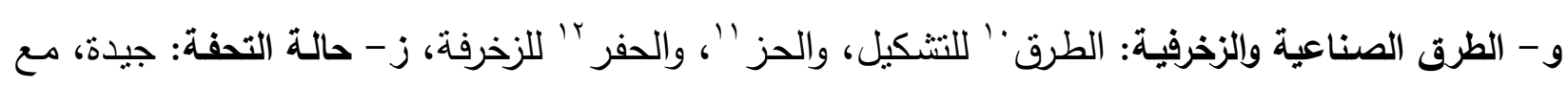

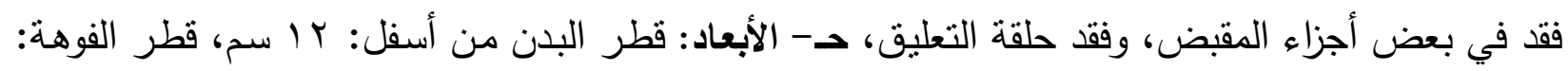

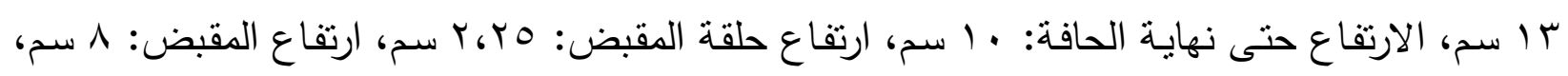

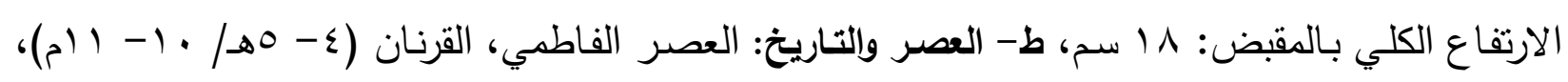
ي - مكان الصناعة: مصر ، ك- المراجع: تتشر التحفة لأول مرة.

1, I, I. الوصف: يتكون هذا الدلو من بدن، وحافة، وحلقتين للمقبض، ومقبض، بدن هذا الدلو أسطواني

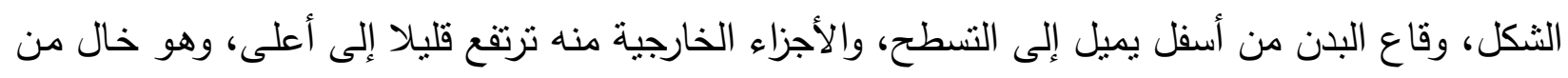

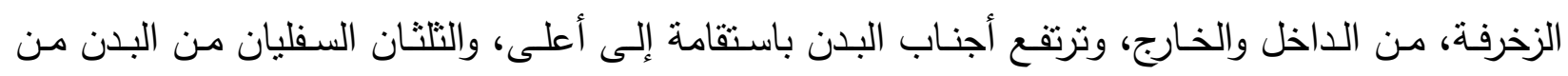

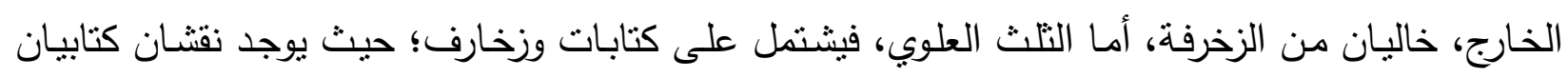

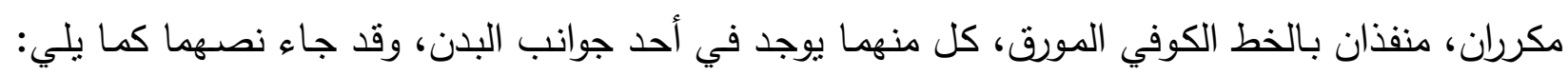

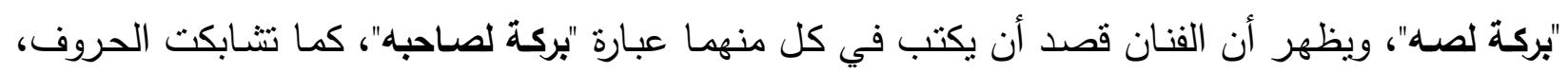

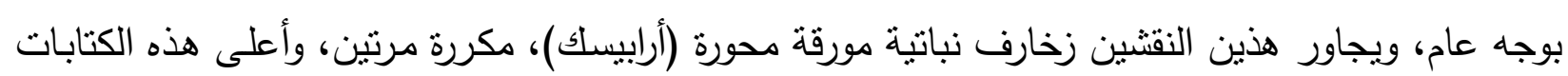

9 البرونز : أحد سبائك النحاس، ويتكون من النحاس الأحمر والقصدير بنسب معينة، وقد يضـاف إليهمـا بعض المعادن

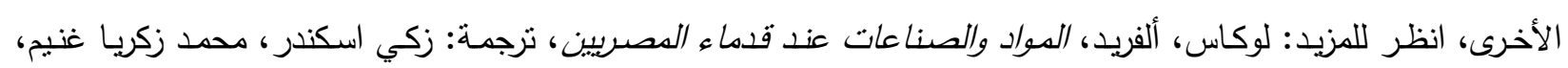

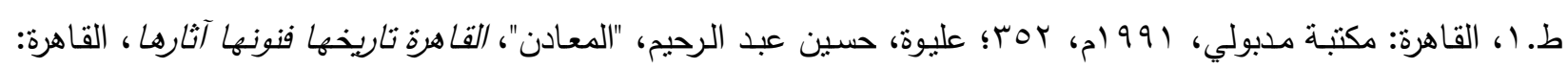

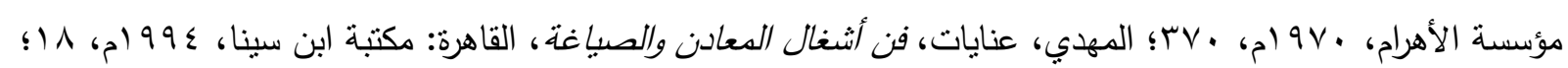
DAVIS, J.R.: Copper and Copper Alloys, ASM Specialty Handbook, USA: AMS international, 2001, 35- 53; ZAHNER, L.W.: Copper, Brass, and Bronze Surfaces: A Guide to Alloys, Finishes, Fabrication and Maintenance in Architecture and Art, Hoboken \& New Jersey: John Wiley \& Sons, 2020, 66.

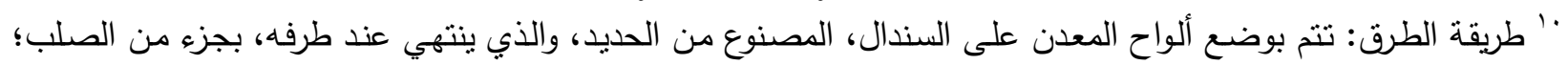

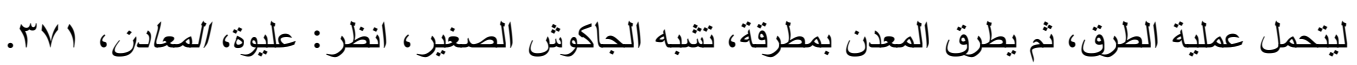

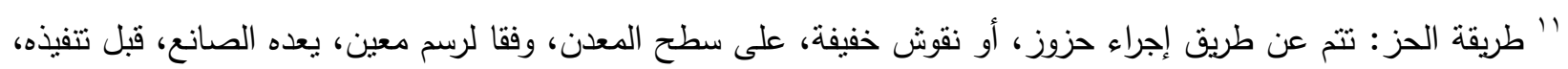

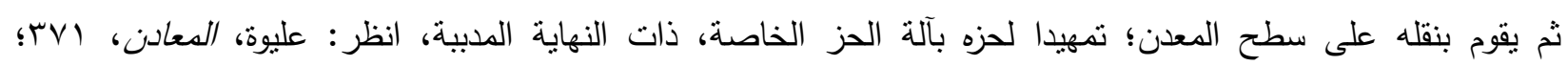

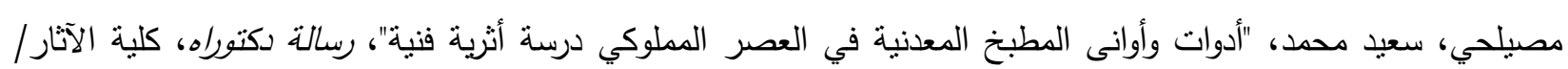

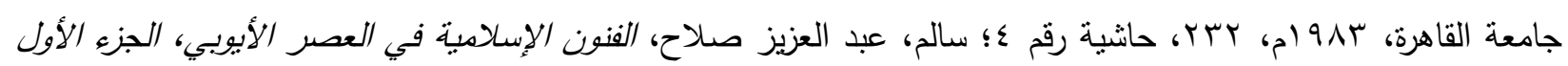

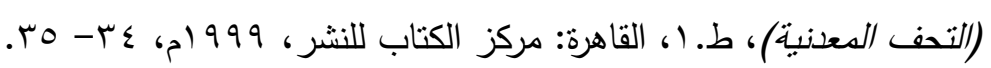

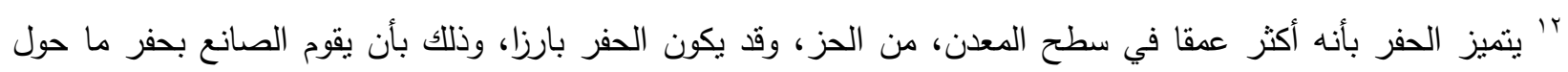

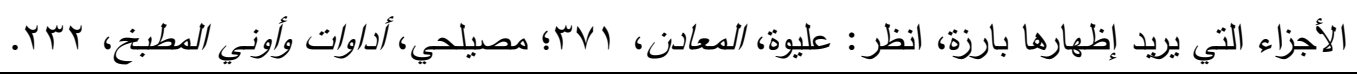


والزخارف، يوجد شريط زخرفي يشتمل على كتابات منفذة بالخط الكوفي المور، بعض كلماتها غير دقيقة، وبعضها غير مقروء، والعبارات في بعض الأحيان غير منوافقة مع بعضها، يقرأ منها عبارة "وعافية شاملة ويقاء لـه وغبطة وعافية لـه وشـاملة (... غير مقروء) وشـاملة"، والبدن من الداخل خالٍ من الزخرفة، وحافة الدلو سـيكة، وتبرز إلى الخـارج، وتخلو مـن الزخرفة مـن الداخل والخارج، أمـا الجزء الأفقي منها، فهو مزخرف بخطوط منكسرة منفذة بالحفر الغائر، وبالنسبة لحلقتي المقبض، فهما سميكتان ومتصلتان بالحافة، وتبدأ كل حلقة منهما بجزء متدرج وعريض من أسفل، ويقل هذا العرض نحو الأعلى، وتوجد في الثلثين السفليين من كل حلقة فتحـة دائريـة، وضـع بداخلها أحد طرفي المقبض، أمـا مقبض الدلو، فهو على هيئة نصف دائرة، وينتهي في كل طرف من طرفيه بجزء منثنٍ، يدخل في الحلقة الجانبية، والجزء الأوسط منهه يأخذ شكلا بيضاويا، وبه فتحة دائرية، يبدو أنه كان بها مسمار ، مثبت بـه حلقة، وتوجد حزوز غائرة، على بلى جانبي الجزء الأوسط من المقبض، وكذلك قرب طرفيه.

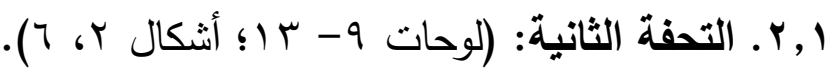
ا, r, ا. البيانـات الأساسية: أ- النوع: دلو، ب- الاستخدام: رفع ونقل الماء، جـ- مكان الحفظ: متحف الفن

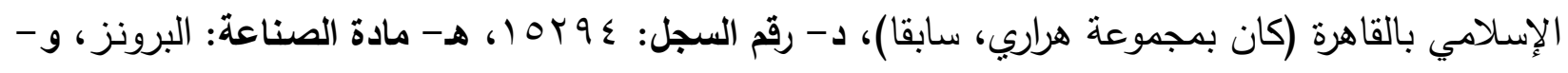
الطرق الصناعية والزخرفية: الطرق للتشكيل؛ والحز، والحفر البارز للزخرفة، ز - حالة التحفة: جيدة، مع تلف بسيط، في بعض الأجزاء والزخارف، ح- الأبعاد: قطر البدن من أسفل: 7 سم، قطر الفوهة: V سم، الارتفاع حتى نهاية الحافة: 7 سم، ارتفاع حلقة المقبض: r سم، ارتفاع المقبض: 0 سم، الارتفاع الكلي بالمقبض:

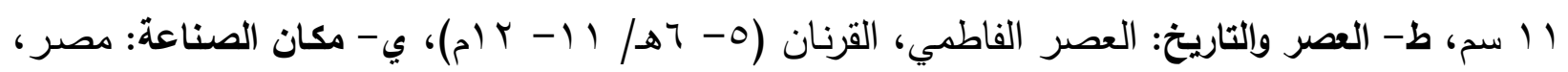
ك- المراجع: تتشر التحفة لأول مرة.

ا, r, ـ الوصف: يتكون هذا الدلو من قاعدة، وبدن، وحافة، وحلقتين للمقبض، ومقبض، القاعدة بسيطة، مكونـة من جزين حلقيين بارزين إلى أسفل ومتحدي المركز ، الداخلي منهما يشتمل في وسطه على جزء وهاء غائر، أما الخارجي فيشتمل على تقعر بسيط في المتتصف، وبدن هذا اللالو ضيق من أسفل ومتسع من أعلى، وقاع البدن خال من الزخرفة من الخارج والداخل، ويوجد انحناء عند نقطة التقائه بجدار البدن، ويوجد في الجزء السفلي من البدن إطلار زخرفي صغير، يثتنل على أثنكال أقواس صغيرة متجاورة، ومحدد من أعلى ومن أسفل بخطين منفذين بالحز ، ويوجد على البدن شريطان زخرفيان، السفلي منهما يشتمل على

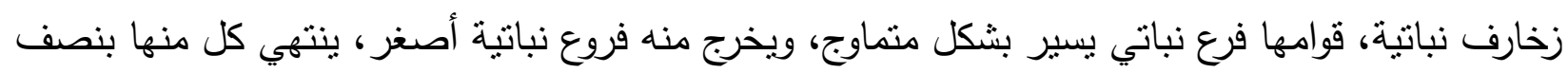
مروحة نخيلية، ويوجد أعلى وأسفل هذا الشربط الزخرفي إطاران صغيران، يشتمل كل منهما على أشكال أقواس صغيرة متجاورة، ومحدد من أعلى ومن أسفل بخطين منفذين بالحز، أما الثريط العلوي، فيشتمل على إنى كتابـات منفذة بـالخط الكوفي المورق، يظهر منها عبـارة "بركـة كاملـة ونعمـة شـاملة و .... تامـة"، لكن من 
الواضح أن الكتابة بها أخطاء، وبعض العبارات غير متتاسقة، والبدن من الداخل خال من الزخرفة، وحافة

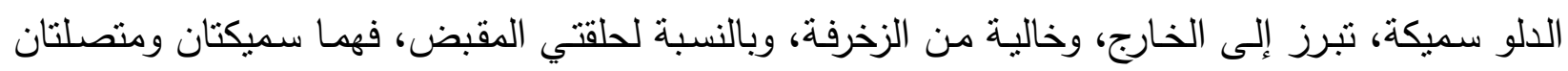

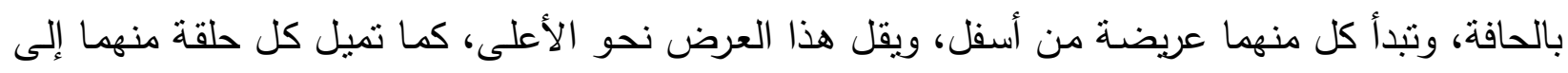

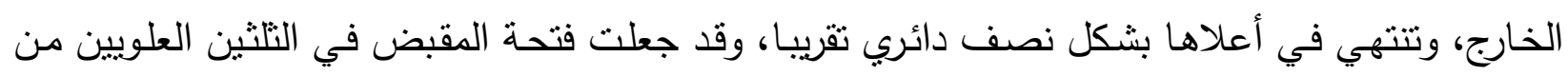

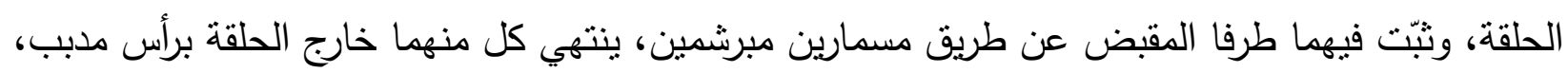
أما مقبض هذا الدلو، فيتميز بكبر حجمه، وضخامة تصميمه، مقارنة بحجم هذا الدلو ، ويأخد المقبض هيئة قوس عريض، مثبت في منتصفه جزء بارز ينتهي بهيئة بصلية الثكل، ذات نهاية بارزة قليلا.

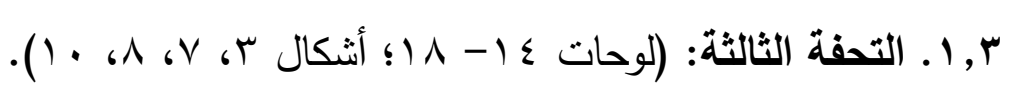

1, 1, ألبيانات الأساسية: أ- النوع: دلو ، ب- الاستخدام: رفع ونقل الماء، جـ- مكان الحفظ: متحف

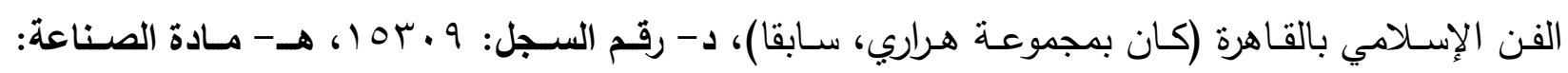

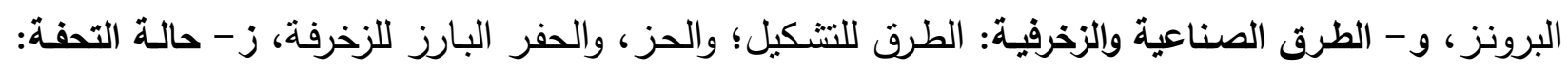
جيدة، مع فقدان المقبض، ح- الأبعاد: قطر البدن من أسفل: 9 سم، قطر الفرفة الفوهة:

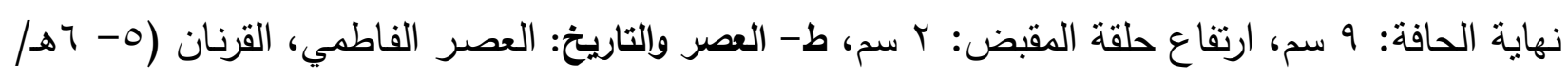
1)

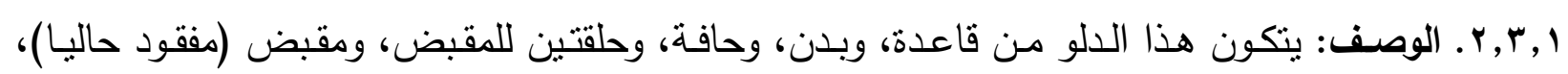

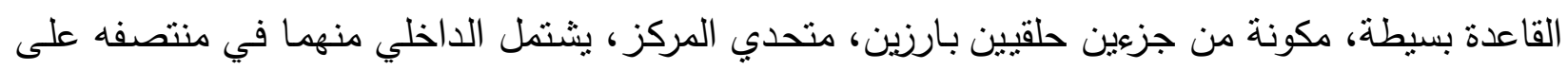

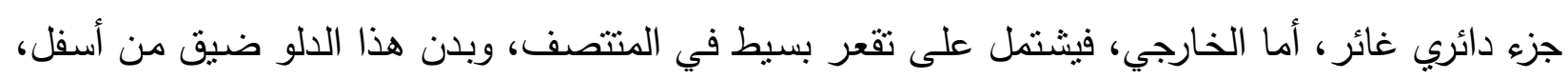

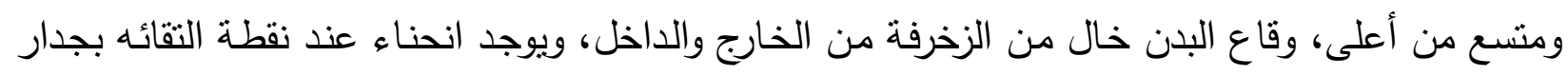

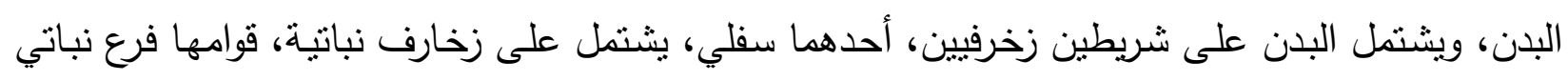

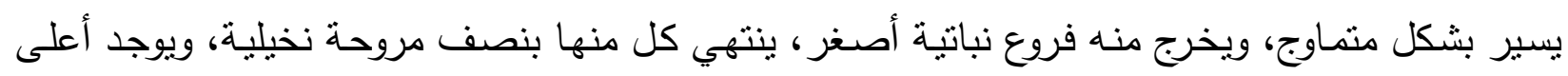

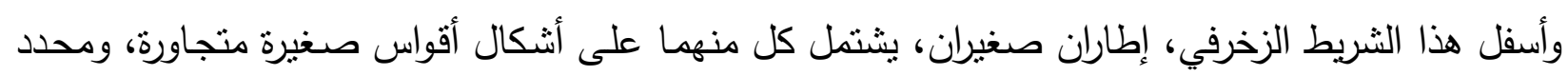

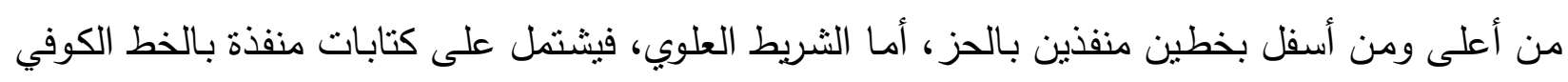

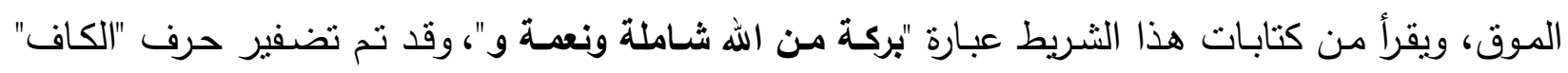

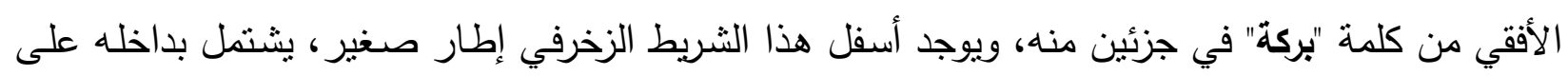

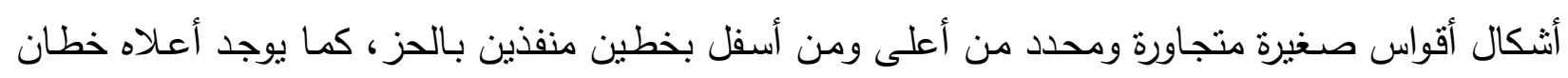

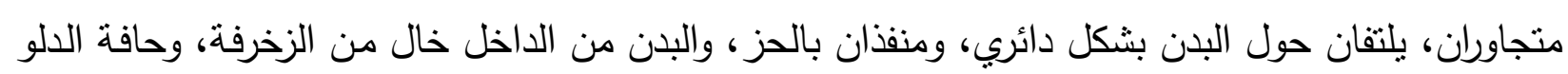

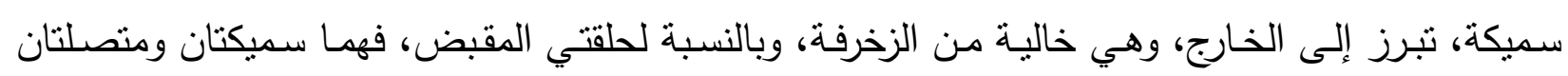

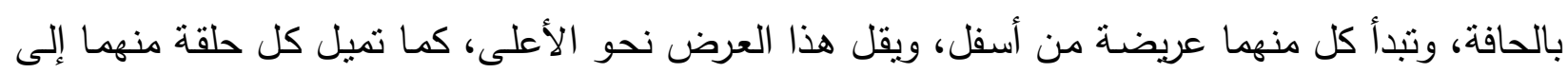


الخارج، وتتنهي في أعلاها بشكل نصف دائري تقريبا، وقد جعلت فتحة المقبض في التنثين العلوبين تقريبا، من الحلقة، والمقبض مفقود، وقد بقي في إحدى الحلقتين مسمار ، كان مستخدما في تثبيت المقبض.

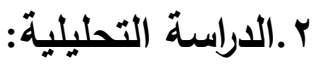
ץ, اـ التصميم: ستتم دراسـة تصميم الدلاء البرونزية (موضوع الدراسـة)، من خـل النقطتين التاليتين: أالتصميم الفني وعلاقته بالوظيفة، ب- طرز تصميم هذه الدلاء، وذللك كما يلي:

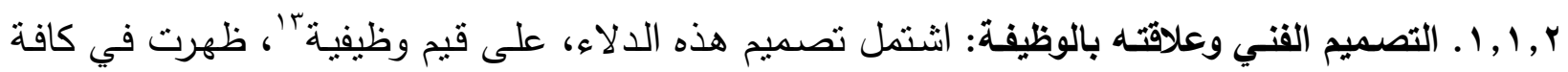

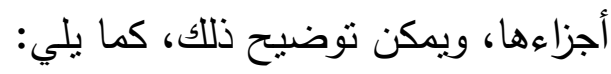

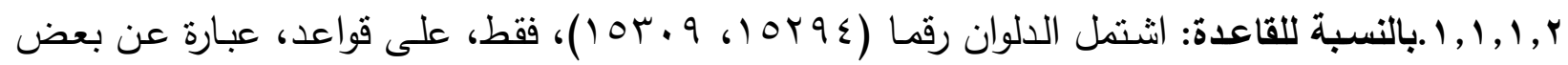

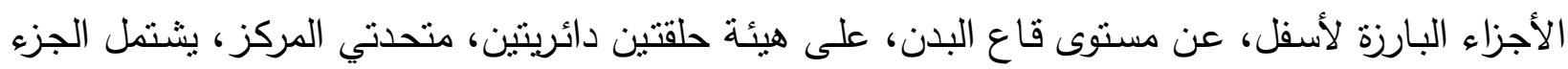

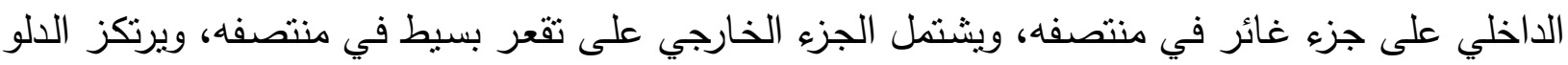

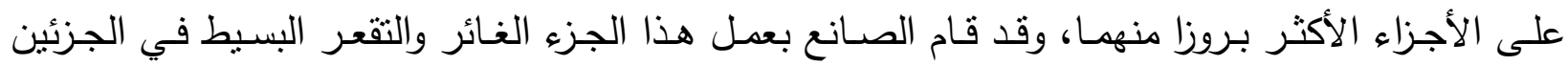
البارزين؛ وذلك حتى لا يكون هذان الجزءان مسطحين تماما، فيلتصق الدلو أحيانا بالجزء الموجود أسفله. أما

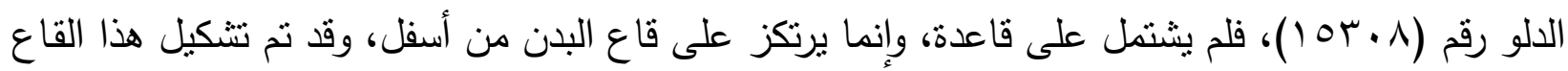

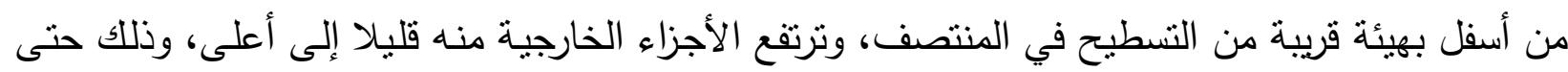

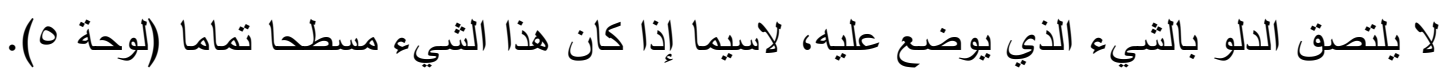

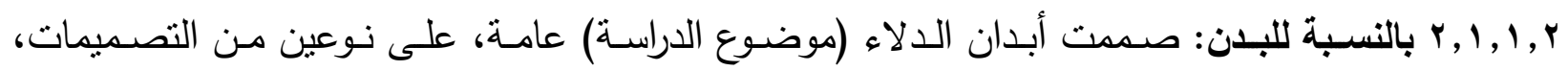

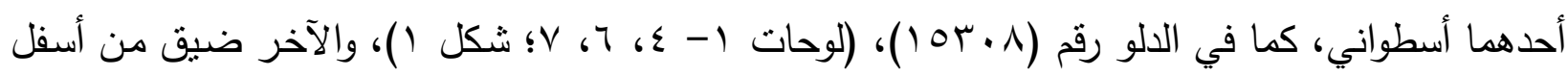

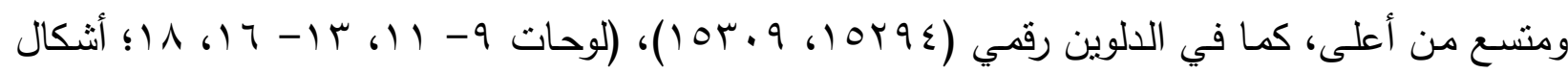

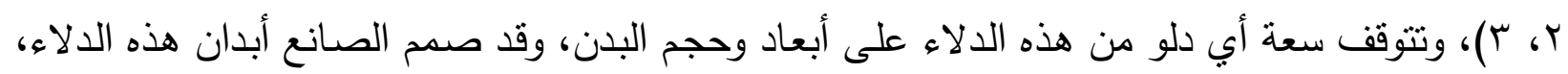

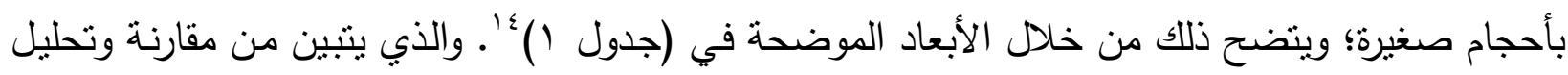

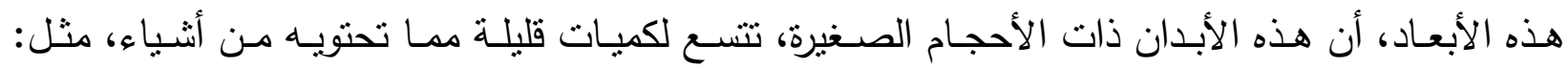
السوائل، وغيرها.

r" القيم الوظيفية: هي مجموعة حقائق تعبر عن التركيب التصميمي، ويهتم المصمم بتطبيقها في تصميم المنتج؛ بغية الوصول

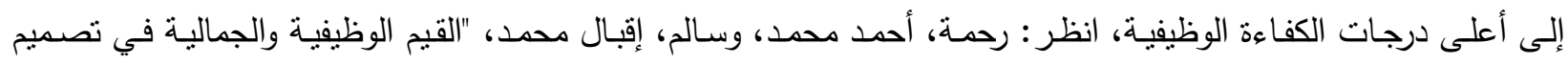

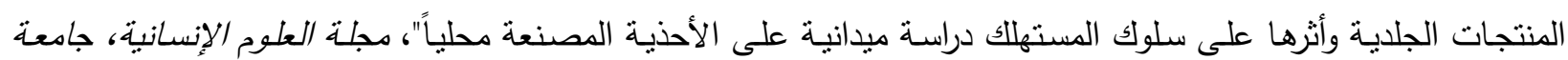

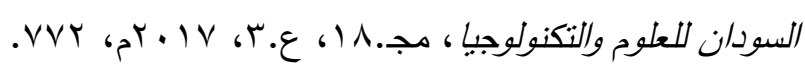
؛' انظر (جدول ()، ضمن مناقثة وظيفة هذه الدلاء. 


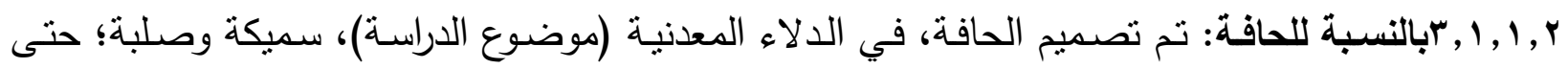

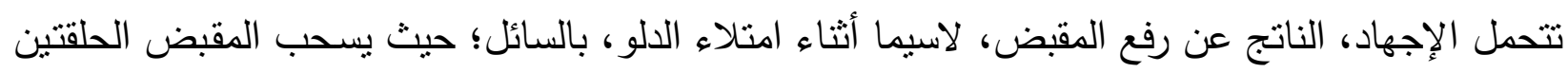

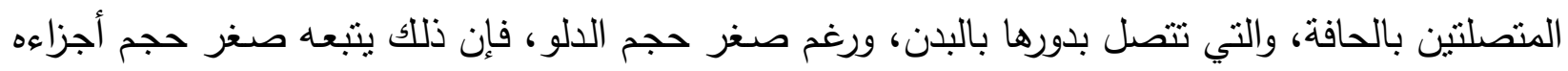

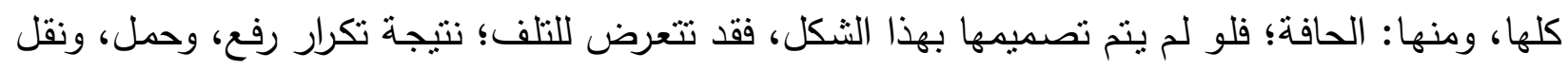
الدلو، لاسيما وهو ممنلئ، كما تم جعل الحافة بارزة قليلا إلى الخارج، وهذا يفيد في ناحيتين: الأولى، أثناء

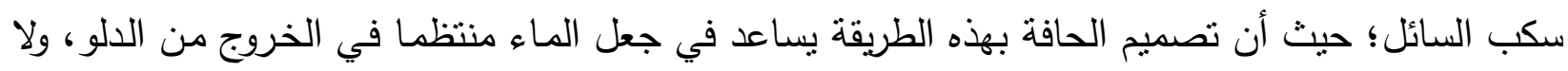
ينسكب بشكل غير منتظم على بدن الدلو، أما الثانية، فإن الحافة البارزة نساعد في حمل فئل الدلو ، وبشكل

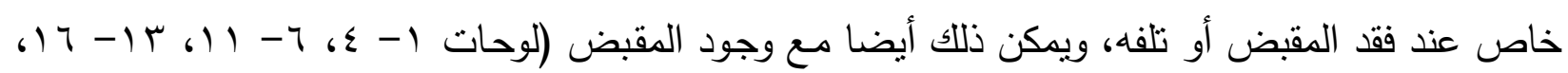

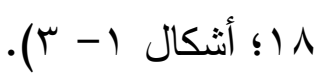

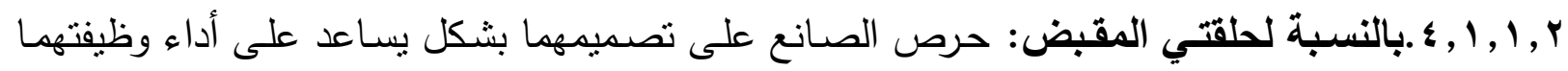

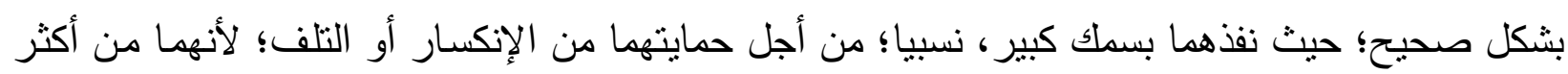

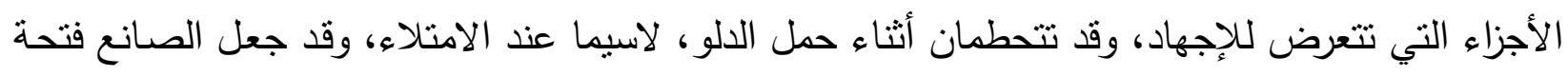

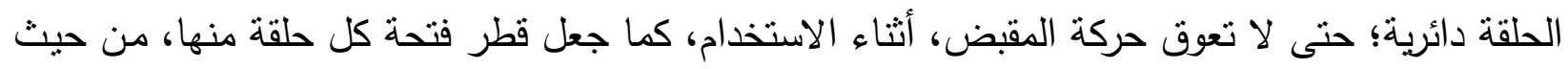

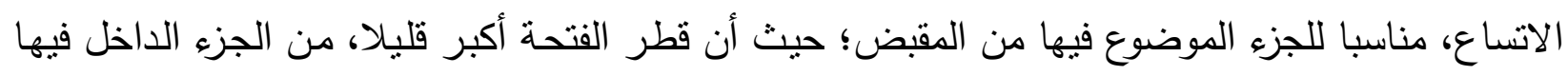

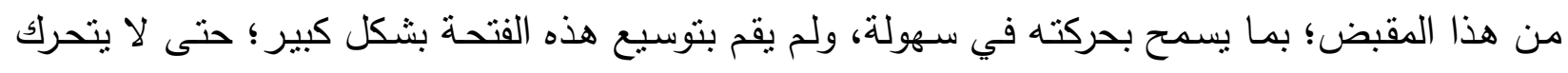

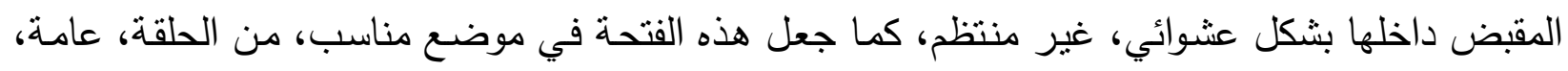

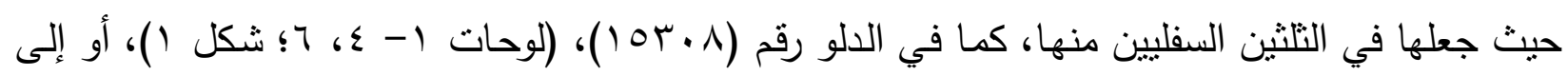

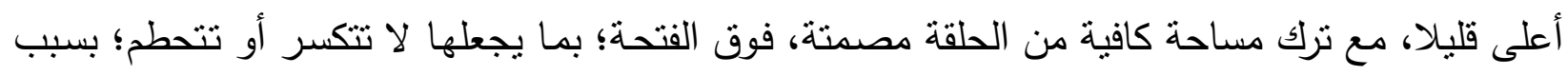

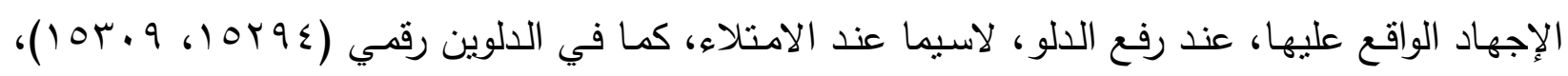

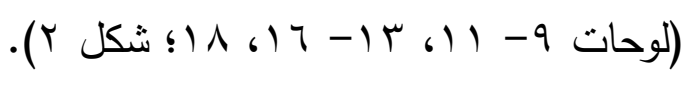

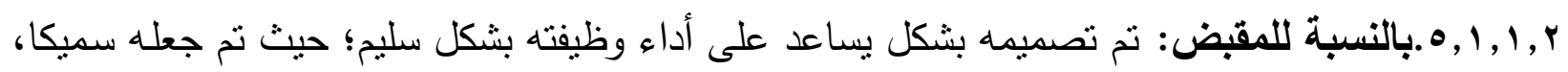

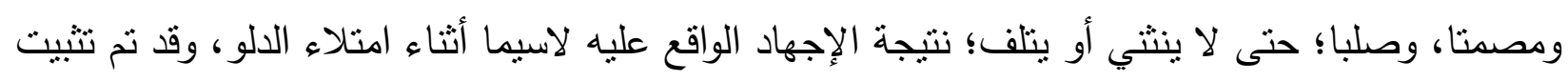

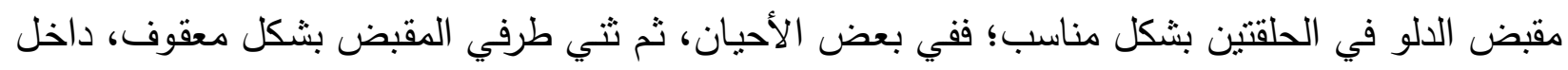

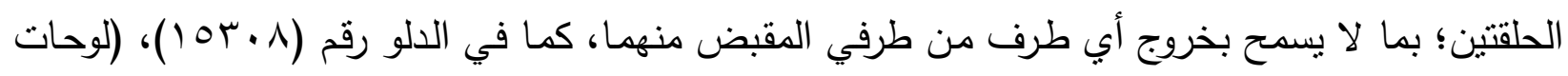

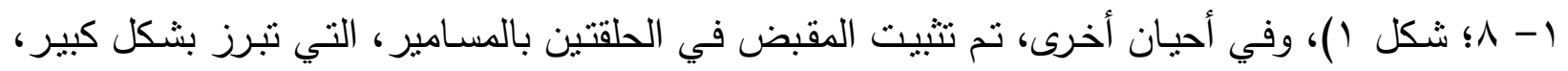

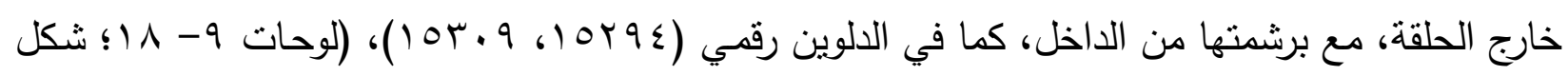

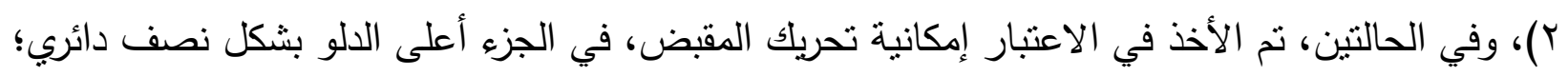

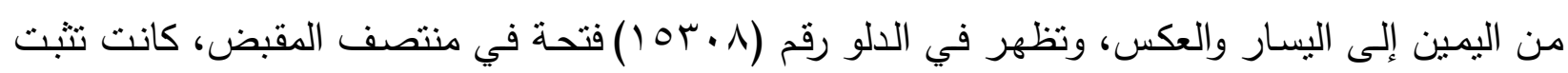

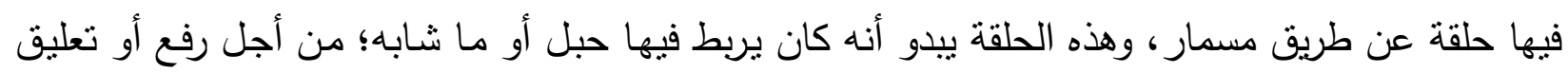


الدلو، بحسب الغرض المستخدم فيه، ووجود هذه الحلقة في منتصف المقبض تماما، يساعد في حفظ اتزان

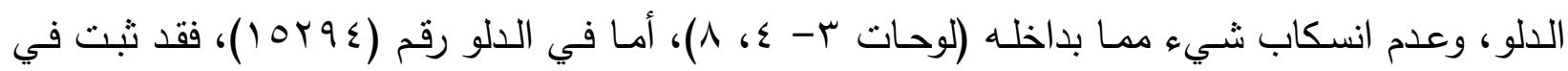
منتصف المقبض جزء كبير بارز، يشبه الأجزاء البارزة من المسامير المستخدمة في تثبيت نهايتي المقبض، ويفيد هذا الجزء في الإمساك بالمقبض ورفعه، كما يفيد أيضا عند ربط حبل بالمقبض؛ حيث يمنع إنزلاق الحبل إلى أحد الجانبين؛ مما يمنع انسكاب شيء مما بداخل الدلو، (لوحات و- r ا؛ شكل r)، وبيدو أن

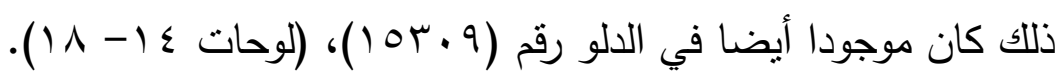

Y, Y.طرز تصـميم هذه الـدلاء: في ضـوء الدراسـة الوصفية، للدلاء (موضـوع الدراسـة)، ودراسـة تصميمها الفني، وعلاقته بالوظيفة (كما ذُكر سابقا)، نجد أن طرز تصميمها، بوجه عام، تتقسم إلى طرازين، ويمكن توضيح خصائص كل منهما، كما يلي:

Y, Y, ا.الطراز الأول: يتميز ببدن أسطواني، قاعه يميل إلى التسطح، والأجزاء الخارجية منه مرتفعة قليلا إلى أعلى، وينتظ البدن في الارتفاع، وتميل أجنابه إلى الاستقامة إلى أعلى؛ بحيث أن اتساع الجزء السفلي منه متساو، أو متساو تقريبا مع اتساع الجزء العلوي، ويشتمل على مقبض سميك، يوجد في كل طرف من طرفيه جزء معقوف؛ لتثبيته في فتحتي الحلقتين، وبمنتصف هذا المقبض، توجد فتحة مخصصسة لتبيت حلقة،

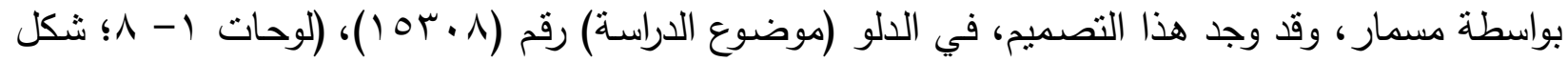
()، وهذا التصميم قد وجد في بعض نماذج الدلاء التي وصلتتا، من صناعة مصر ، في العصر الفاطمي، القرنين (ع- مهـ/ • 1- ('ام)، ومن ذلك: دلو من البرونز، محفوظ بمجموعة كير 10 (لوحة 9 ())، وهناك بعض الـلاء تتشـابه بشكل كبير مـع هذا النـوع، مـع اختلاف معين، مثل: تثبيت المقبض في الجـانبين بالمسـامبر المبرشمة، ومن ذلك: دلو من البرونز ، من صناعة مصر ، في العصر الفاطمي، القرن (0هـ/

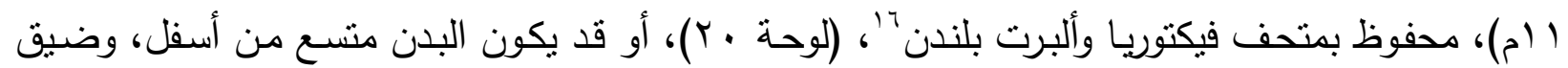
قليلا، من أعلى، ويشتمل على مقبض عربض، ومن ذلك: دلو من البرونز، من صناعة مصر، في العصر

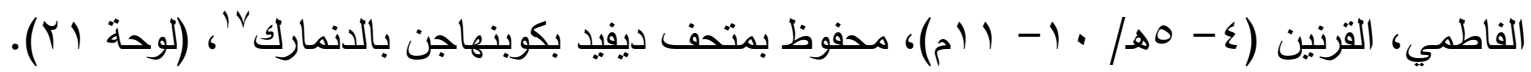

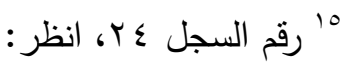

FEHÉRVÁRI, G.: Islamic Metalwork of the Eighth to the Fifteenth Century in the Keir Collection, $1^{\text {st }}$ ed., London: Faber and Faber Limited, 1976, 47, pl. 8b.

14 19 رقم السجل M.25-1923، انظر: BloOM, J.M.: Arts of the City Victorious: Islamic Art and Architecture in Fatimid North Africa and Egypt, London and New Haven: Yale University Press, 2007, 98- 99, fig. 69.

' رقم السجل 87/2003، انظر : https://www.davidmus.dk/en/collections/islamic/dynasties/tulunids-and-fatimids/art/87-2003 (Accessed October 17, 2020). 


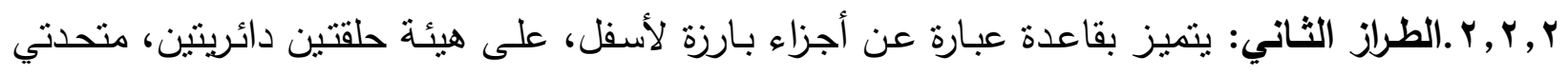

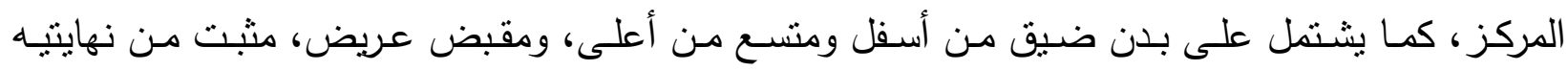
بمسامير مبرشمة، ويشتمل هذا المقبض في منتصفه على جزء بارز، مثبت بالبرشمة، وقد وجد هذا التصميم

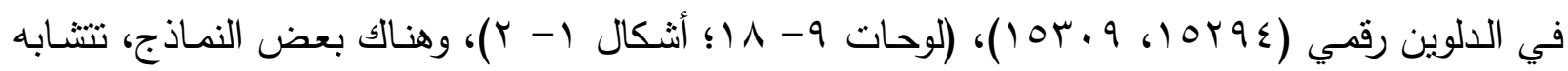
من حيث التصميم مع هذين الالوين، ومن ذلك: دلو من البرونز، من صناعة مصر، في العصر الفاطمي،

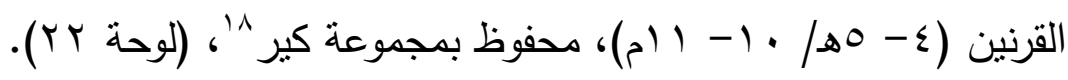
r. الكتابات: تتمنك الكتابات الواردة على هذه الدلاء فيما يلي: r, ا. الكتابات من حيث الشكل: استخدم في تتفيذ الكتابات، على هذه الدلاء، كل من الخط الكوفي المورق، والكوفي المضفر ، ويمكن توضيح ذلك كما يلي:

- الخط الكوفي المـورق: استخدم الخط الكوفي المورق '1، في تتفيذ الكتابات على الدلاء الثلاثتة (موضوع

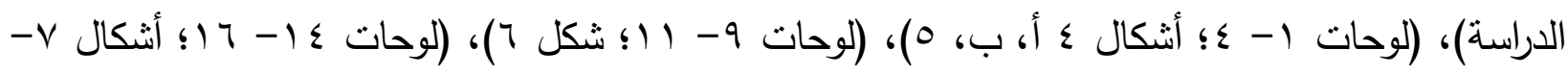
^). وقد بدأت ظاهرة التوريق، في صورتها الأولى، في مصر ، قبل أن يتقدم القرن الثاني الهجري، ونمت وتطورت قبل منتصف القرن الثالث الهجري، ويعتبر التوريق الفاطمي غاية ما بلغته هذه الظاهرة، من النمو والتطور بr.r. - الخط الكوفي المضفر أو المجدول: استخدم الخط الكوفي المضفر أو المجدول 'ب، في كلمة واحدة، ضمن كتابات الثربط المنفذ في الجزء العلوي، من البدن، على الدلو رقم (9 . به ()، وهي كلمة "بركة"؛ حيث قام

Fehérvári, G.: Islamic Metalwork, 47- 48, pl. 8c.

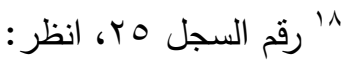
19 الخط الكوفي المورق: نوع من الخط الكوفي، نتبعث من حروفه القائُة، أو حروفه المستلقية، وبالأخص الحروف الأخيرة

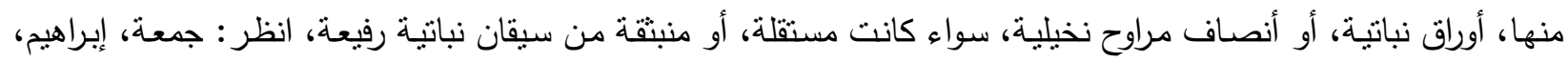

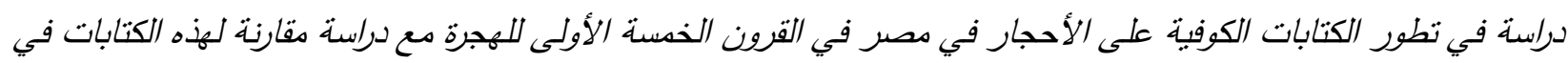

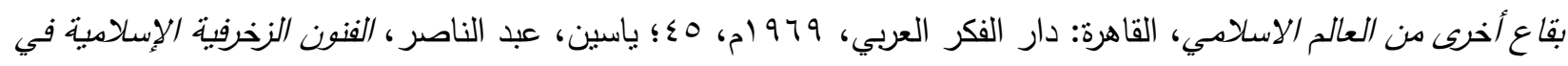

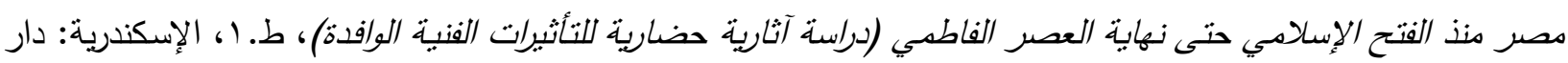

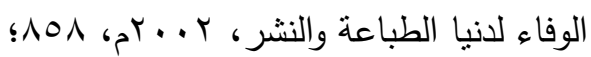
GroHmAnN, A.: «The Origin and Early Development of Floriated Kūfic», Ars Orientalis 2, 1957, 183 figs. 1 and 2.

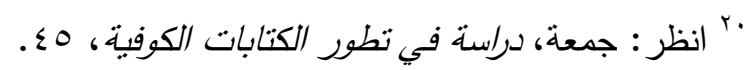

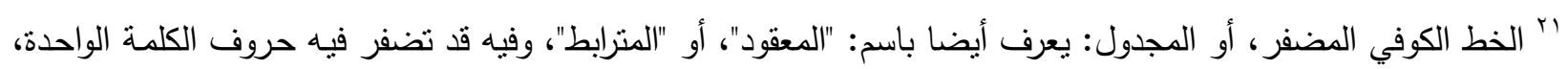
أو تضفر حروف كلمنين متجاورتين أو أكثر؛ لكي ينشأ من هذا شكل جميل، وقد يبالغ في تعقيده إلى حد يصعب معه تمييز العناصر الخطية من العناصر الزخرفية، انظر : جمعة، دراسة في تطور الكتابات الكوفية، 0؛؛ عليوة، حسين عبد الرحيم،

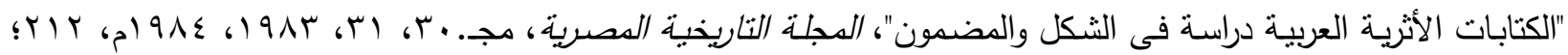

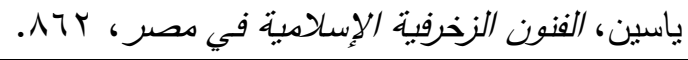


بتضفير حرف "الكاف" الأفقي مرتين، في جزئين منه (لوحة 7 (؛ شكل ^)، وأقدم الأمتلة المعروفة من الخط

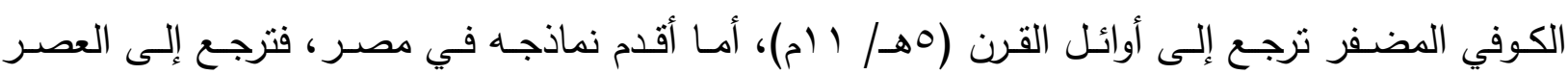

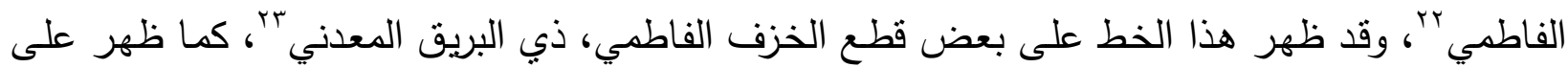
بعض العمائر الفاطمية، التي ترجع إلى أواخر القرن الخامس، وخلال القرن السادس الهجربين؛ ومن ذلك:

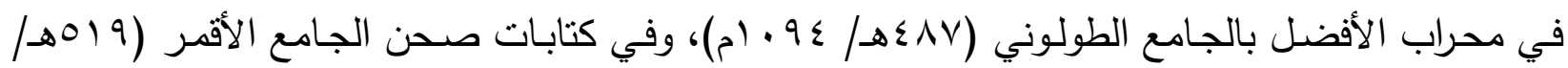

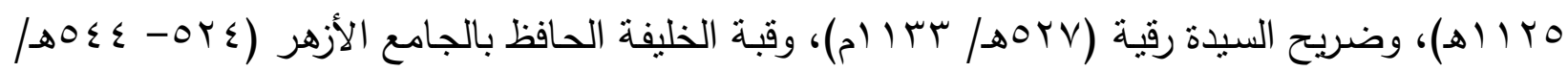

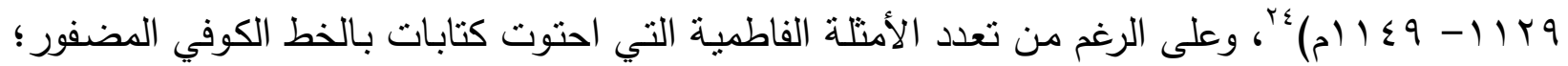
إلا أنه يلاحظ أن جميعها قد اتسم ببساطة التضفير مب، وتجدر الإشارة إلى أن بساطة التضفير كانت متحققة في الكتابة على الدلو (موضوع الدراسـة) رقم (9 • به (1)؛ مما يشير إلى أن الفترة الزمنية، لهذا الدلو وتلك الأمتلة متقاربة، كما أن التضفير في كتابات الدلو رقم (9 . rه ()، والذي وجد في جزئين من حرف "الكاف"، من كلمة "بركة"، قد كون ثناثة أجزاء مستطيلة، وهو يعد متطورا مقارنـة بالتضفير في كتابـات قارورة من البلور الصخري، تتسب إلى مصر ، في منتصف القرن (عه/ · (م)، محفوظة بمجموعة كير، وقارورة أخرى، بمتحف ولاية برونزويك بألمانيا؛ حيث تشنمل كتابات كل منهما على تضفير على هيئة مستطيلين(بr)، وهذا يثير إلى أن كتابات الدلو رقم (9 • به ())، تتنمي إلى فترة نالية لفترة صناعة هاتين القارورتين. وتتثـابه الكتابات، من حيث أثنكال الحروف، على الدلاء الثناثتة (موضوع الدراسـة)، مـع الكتابات على العديد من التحف التطبيقية في مصر، في العصر الفاطمي، ومن ذلك: الكتابات على زبدية من الخزف

rr هناك اختلاف في أصل نشأة الخط الكوفي المجدول؛ ما بين نشاته في شرق العالم الإسـامي (إيران)، أو غربه (القيروان)،

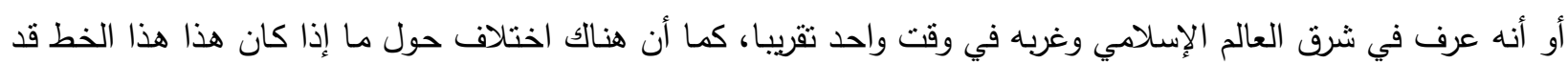
جاء إلى مصر الفاطمية بتأثنر من شرق أم غرب العالم الإسلامي، انظر للمزيد: جمعة، دراسة في تطور الكتابات الكوفية،

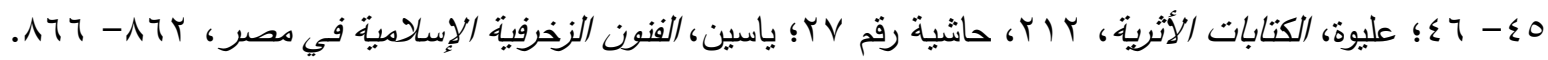
${ }^{23}$ PHILON H.: Early Islamic Ceramics: Ninth to Late Twelfth Centuries, Benaki Museum Athens Catalogue of Islamic Art, Vol. 1, London: Islamic Art Publications, 1980, figs. 498, 500- 503, 505- 508, 513.

ع بانظر : عبد الوهاب، حسن، تاريخ المساجد الأثرية، جزءان، سلسلة ذاكرة الكتابـة (109)، القاهرة: الهيئة العامـة لقصور

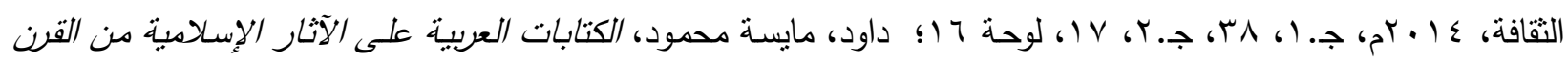

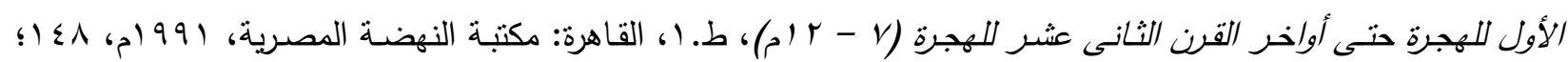

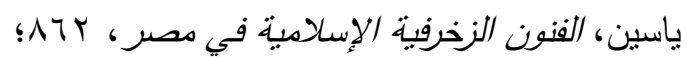
BURCKHARDT, T.: Art of Islam Language and Meaning Commemorative Edition, Bloomington, Indiana: World Wisdom, 2009, 143, pl. 197.

• وذللك بالمقارنة بنلك النماذج التي وصلتنا من مصر ، في العصر الأيوبي، والتي تميزت بشدة تعقيدها وتطورها، علاوة على

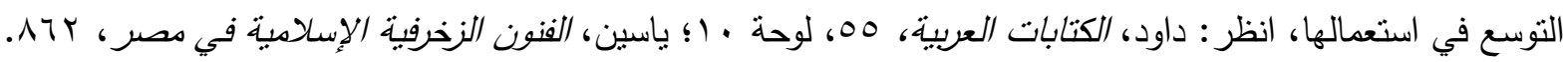

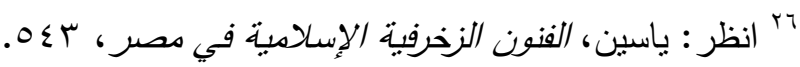


ذي البريق المعدني، من القرنين (0- Tه// I- Y (م)، محفوظة بمتحف الفن الإسـامي بالقاهرة، وتتضمن هذه الكتابات عبارة دعائية، نصها "تعمة شاملة ويركة كاملة"، رغم وجود خطأ في كتابـة كلمة "كاملة"(YV)، كما تتتابه مع الكتابات على طبق من الخزف ذي البريق المعدني، من القرنين (0- 7 هـ/ ( 1 (- ب (م)، محفوظ بمتحف الفن الإسـلامي بالقاهرة، ويشتمل على كتابـات غير مقروءة، يبدو أن المقصـود منها كان بعض العبارات الدعائية، ، وهذا يشير إلى التقارب الزمني بين الدلاء (موضوع الدراسة)، وبين هذه التحف الخزفية، من العصر الفاطمي. r, r. الكتابـات مـن حيـ المضـمون: بوجـه عـام، اقتصـر مضـمون الكتابـات، المنفذة على الـدلاء المعدنيـة (موضوع الدراسـة)، على العبارات الدعائية، فقط، وكانت صيخ العبارات الدعائية، الواردة على هذه الدلاء الثلاثة، كما يلي: - على الدلو رقم (1 • به ( ): "بركة لصه (لصاحبه)"، "وعافية شاملة ويقاء لـه وغبطة وعافية له وشـاملة (.... غير مقروء) وشاملة"، (لوحات ا- (- ع؛ أشكال ع أ، ب، 0). - على الدلو رقم ( 9 (o 1 )): "بركة كاملة ونعمة شاملة و .... تامة"، (لوحات 9- (1) شكل 7$).$

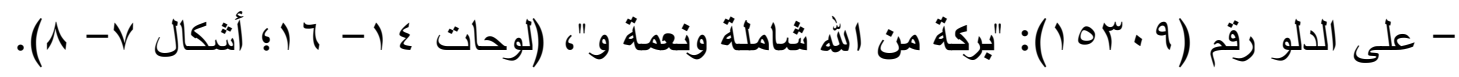
ويظهر في هذه العبارات الدعائية، تتوع الأدعية، بشكل واضح، وكلها أدعية بأمور مرجوة، ومحبذة، من البشر؛ بتمنونها لأنفسهم، وتوضيح ذلك كما يلي: - البركة: تعني الزيادة والنماء - النعمة: تعني الكثير من أمور الخير، منّل اليد البيضاء، والمنة، وما ينعم الله به على العبد ‘ّ. - البقاء: يعني الدوام والاستمرا، دون انقطاع، أو فناء”ب". - العافية: تعني الصحة، ضد المرض، والمعافاة؛ من الأسقام، والعلل، والبلايا(r؟). - الغبطة: تعني حسن الحال، والنعمة، والسرور بَّ.

${ }^{27}$ JenKINS, M.: «Muslim: An Early Fatimid Ceramist», the Metropolitan Museum of Art Bulletin 26, №. 9, 1968, fig. 12, doi: 10.2307/3258401.

${ }^{28}$ JenKINS, M.: «Early Medieval Islamic Pottery: The Eleventh Century Reconsidered», Muqarnas 9, 1992, 60, fig. 14, doi: 10.2307/1523135.

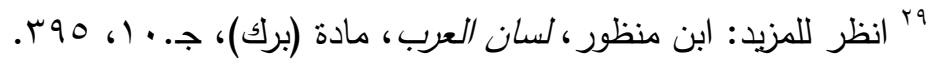

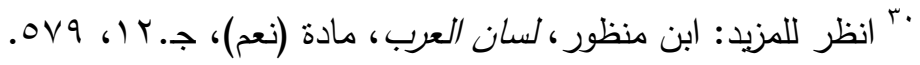

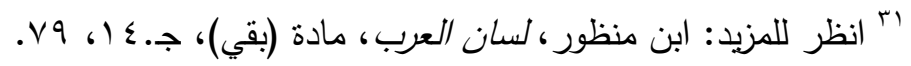

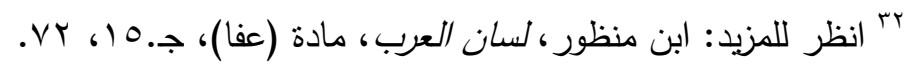

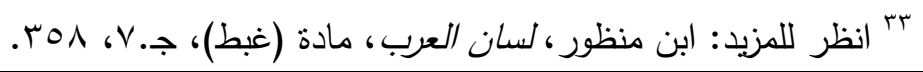


وقد وجدت عبـارات دعائية، متتوعـة، ومشـابهة؛ بشكل، أو بـآخر، على أمثلـة أخرى، مـن الدلاء المعدنية، من صناعة مصر، في العصر الفاطمي، فنجد على دلو من البرونز، من القرنين (ع- 0هـ/ . 1(ام)، محفوظ بمجموعة كير؛ عبارات دعائية، نصها "بركة لصاحبه"، مكررة مرتين، على جانبي البدن، كما يوجد أعلى البدن، شـريط كتابي، بتضـمن عبـارات دعائيـة، نصـها "عز والسـعادة والعافيـة والكرامـة والنعمـة والكاملة والسلامة" عَ، (لوحة 9 ( ))، وهذا يشير إلى تتوع واضـح في العبارات الدعائية، على الدلاء المعدنية، في العصر الفاطمي، بوجه عام. كما تشـابهت العبارات الدعائية، على الدلو (موضـوع الدراسـة) رقم (1 • بـ 1)، إلى حد كبير مـع العبارات الدعائية المنفذة على أنواع أخرى من أشغال المعادن، في مصر، في العصر الفاطمي، ومن ذلك: إبريـق من النحاس الأحمر، مـن القرنين (ع- هــ/ • 1- ( (م)، محفوظ بمتحف الفن الإسـامسى بالقاهرة؛

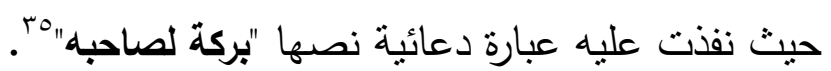
وقد انتشرت العبارات الدعائية المتتوعة؛ بالبركة، والنعمة، والبقاء، والعافية، والغبطة، وغيرها، على تحف معدنية متتوعة، من العصر الفاطمي؛ ولن تكون هناك مبالغة، إذا قيل أن العبارات الدعائية المتتوعة -وعلى وجـه الخصوص، الدعاء بالبركة والنعمـة- كانت من سمات الفنون التطبيقيـة الإسـلامية، في ذلك العصـر، ونجد على تمثنال عقاب مـن البرونز ، ذي الزخـارف المحفورة، مـن صـناعة مصـر ، في العصـر

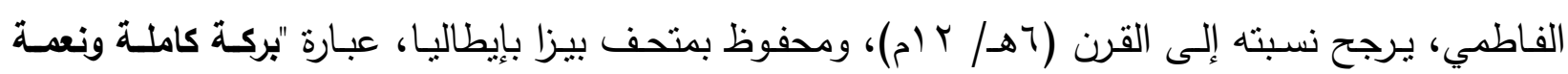

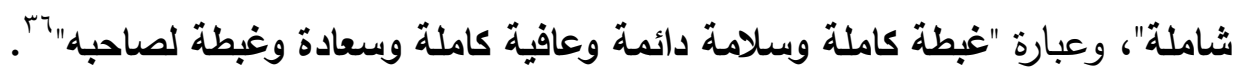
ويلاحظ في هذه الكتابات المنفذة على الدلاء المعدنية (موضوع الدراسـة)، وجود كتابات غير دقيقة،

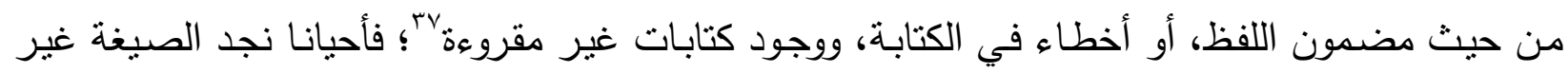
متتاسقة، بـأن لا تكون جمـلا مفيدة وواضحة؛ فعلى سبيل المثنال، قد يضـع حرف عطف أمسام كلمـة غير مناسبة بعده، مثل: لفظ "وشاملة"، وتكرار لفظ، لأكثر من مرة، في النص الواحد، بـلا داع، كما هو الحال،

FEHÉRVÁRI, G.: Islamic Metalwork, 47, pl. 8b.

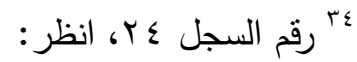

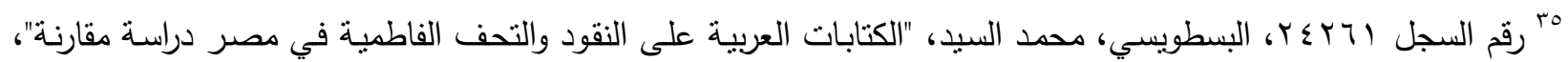

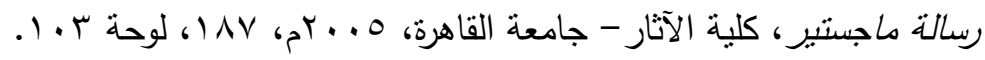

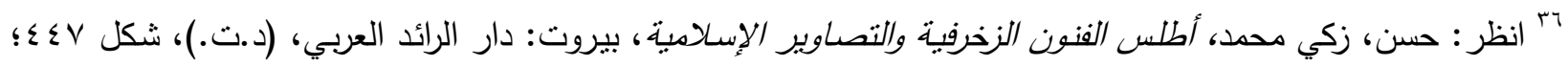

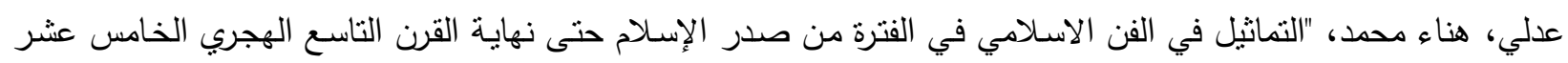

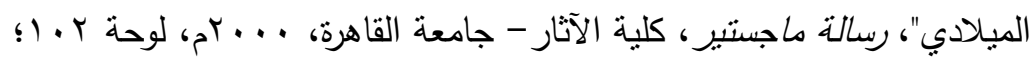
YEOMANS, R.: the Art and Architecture of Islamic Cairo, $1^{\text {st }}$ ed., Lebanon: Garnet Publishing Limited, 2006, 82.

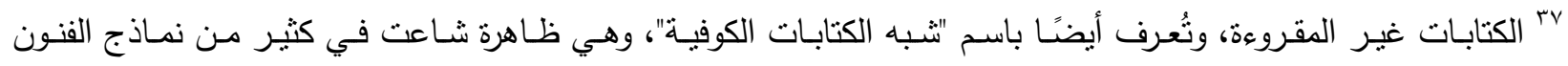

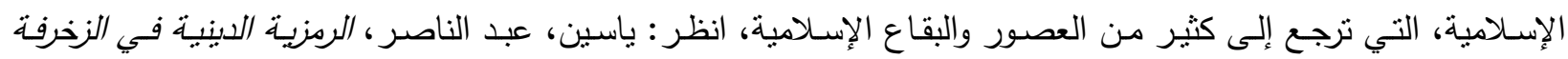

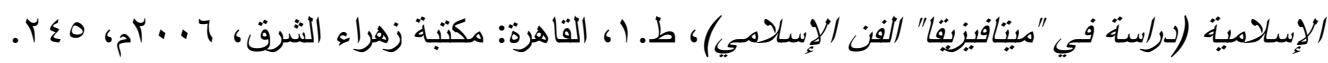


في لفظ "وشـاملة"، ولفظ "وعافية"، في نصوص كتابات الدلو رقم (1 • به 1)، وأحيانا يكتب حرف العطف "و"، بلا كلمات بعده، كما هو الحال على الدلو رقم (9 . و (1)، كما نرى حروفا منسقة في كلمات ليس لها

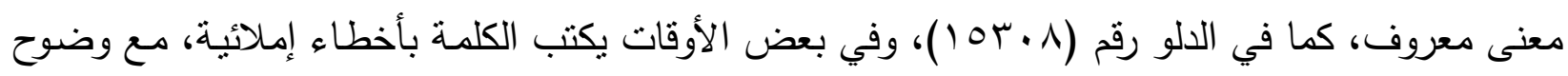

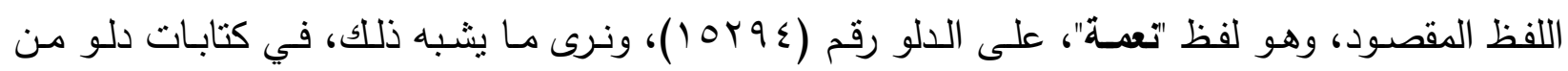
البرونز، من صـناعة مصـر، في العصدر الفاطمي، القرن (0هـ/ ( (م)، محفوظ بمتحف فيكتوريـا وألبرت

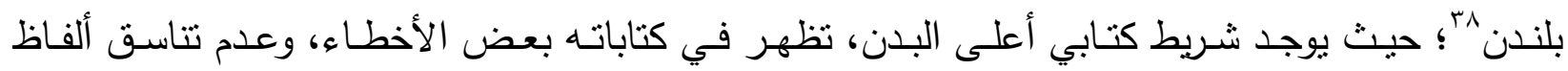

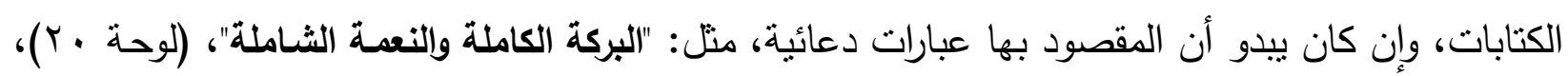
وذلك يبين أن الظواهر الكتابية المثنلة في وجود كتابات غير دقيقة، من حيث مضمون اللفظ، أو كتابات بها أخطاء، أو كتابات غير مقروءة، كانت موجودة، ومنتشرة على العديد من الدلاء المعدنية، في مصر ، في العصر الفاطمي، كما كانت هذه الظواهر من الأمور الموجودة على العديد من التحف التطبيقية، في نفس العصر ، فنجد ذلك في كتابات طبق من الخزف ذي البريق المعدني، من القرن (0ه/ الم)، محفوظ بمتحف هون الفن الإسـامي بالقاهرة"، وكذللك في كتابات طبق من الخزف ذي البريق المعدني، من القرنين (0- 7 هـ/

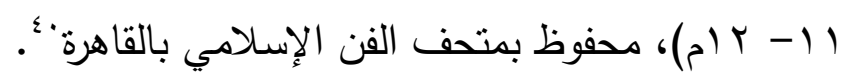

أما عن تفسير هذه الظواهر، فلعل ذلك يعزى إلى أن صناع هذه التحف التطبيقية، بوجهه عام، وهذه

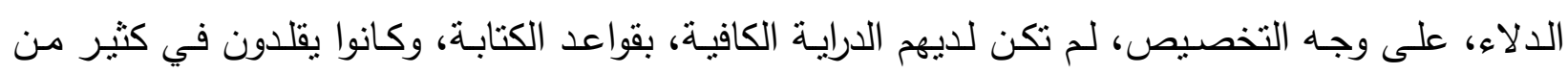
الأحيان النصوص الكتابيـة المتتوعة، على منتجـاتهم، وفقا لذلك القدر من المعرفة، وربما يؤيد ذلك تشابه بعض العبارات الدعائية، بشكل كبير ، على الدلو (موضوع الدراسـة) رقم (1 • ـه ( )، مـع العبارات الدعائية، على طبـق مـن الخزف ذي البريـق المعدني، مـن العصـر الفـاطمي، محفوظ بمتحف الفريـر جـاليرى للفن

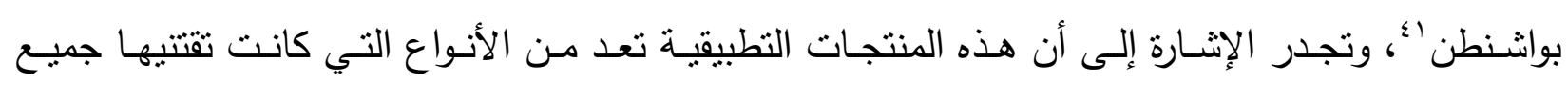
الطبقات؛ من الأغنياء، وعامة الثعب؛ وبالتالي تتفاوت فيها درجات الأداء والجودة، كما كان صانع القطعة يقوم بأداء معظم مراحل إنتاجها؛ من صناعتها، إلى زخرفتها، إلى تتفيذ كتاباتها؛ وعادة لم يكن يخصص لها ولهاء خطاط متمرس r.

BLOOM, J.M.: Arts of the City Victorious, 98- 99, fig. 69.

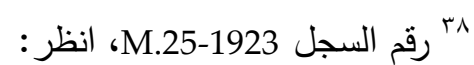

${ }^{39}$ YeOMANS, R.: the Art and Architecture of Islamic Cairo, 85.

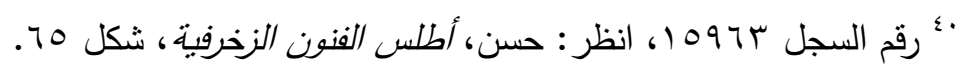
اء وذلك على سبيل المثال، لا الحصر ، انظر : HiLlenBRAND, R., Islamic Art and Architecture, London: Thames and Hudson, 1999, 81, fig. 41. rأ وذلك خلافا لما كان يحدث على العمائر، التي كان يخصص لكتابتها خطاط، لاسيما وأنها كانت تتفذ للحكام وكبار رجال

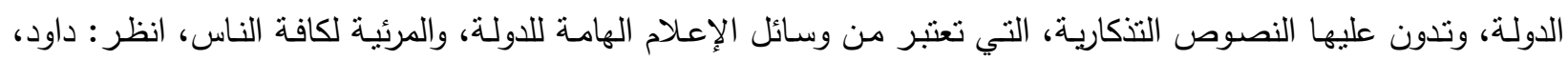

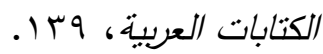




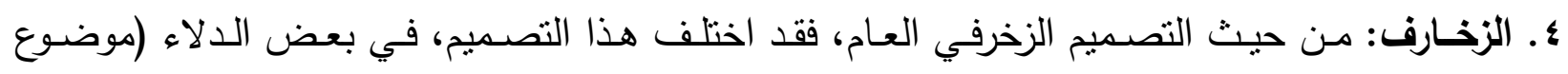
الدراسـة)، عن البعض الآخر ، ويمكن إدراج هذه التصميمات الزخرفية، ضمن تصميمين رئيسين، يمكن التهن توضيحهما كما يلي: عن البطن

؛ , ا.التصميم الأول: يتميز بالبساطة، ويشتمل على شريط زخرفي واحد، موجود في أعلى البدن، يشتمل على

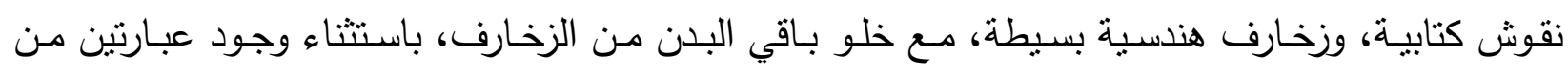

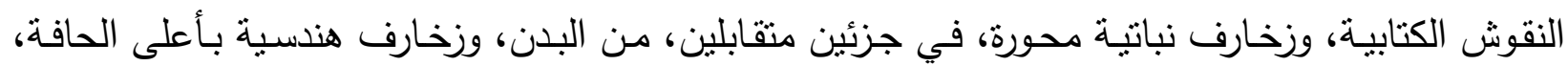

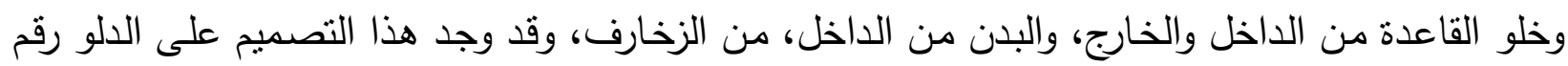

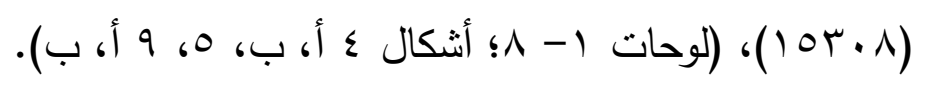

צ , r. التصميم الثاني: يتميز بالتعقيد، والتتوع، ويشتمل على زخارف تتنظم في أثشرطة، وقد تتوعت ما بين

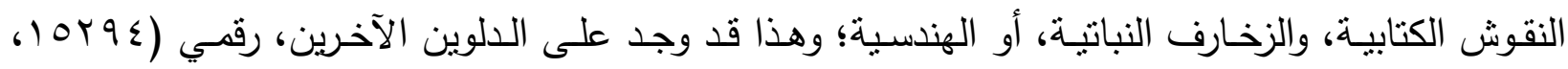

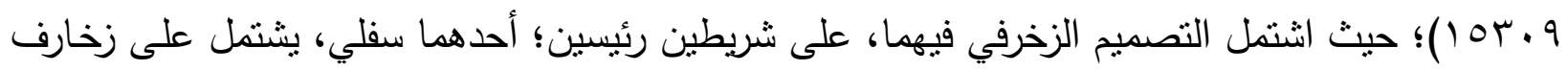

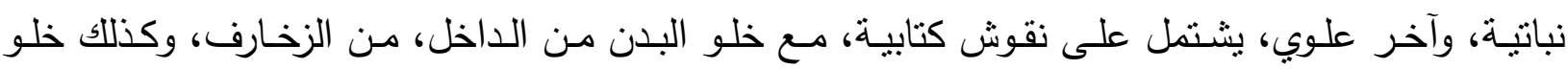

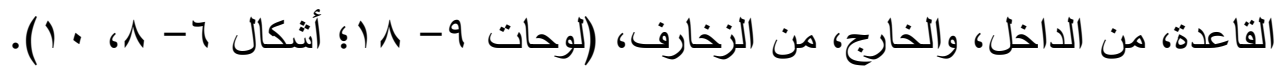

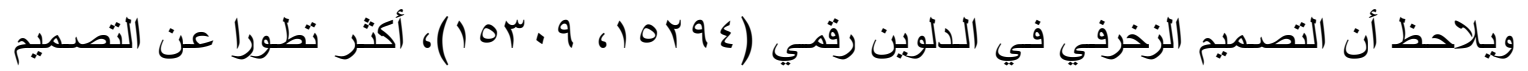

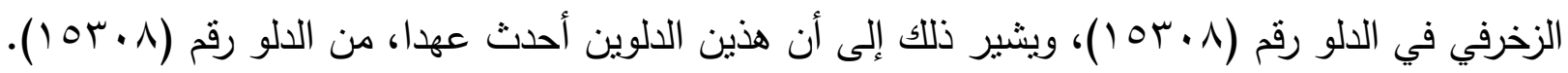
وقد تتوعت التصميمات الزخرفية، على دلاء أخرى، من صناعة مصر ، في العصر الفاطمي؛ فقد

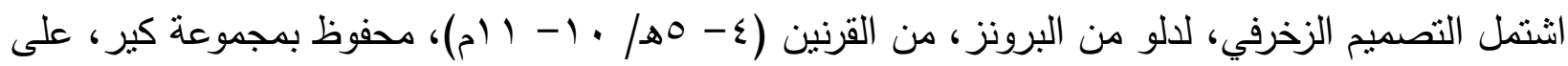

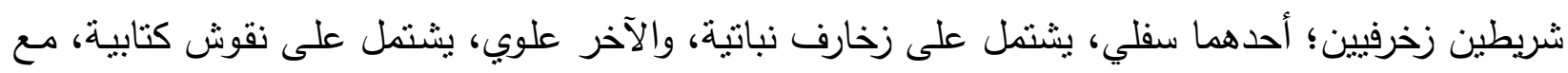

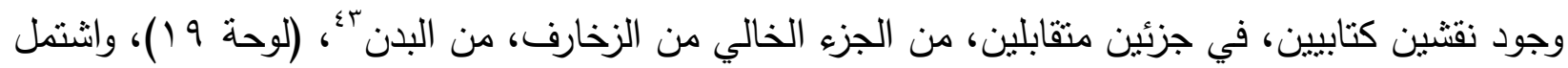

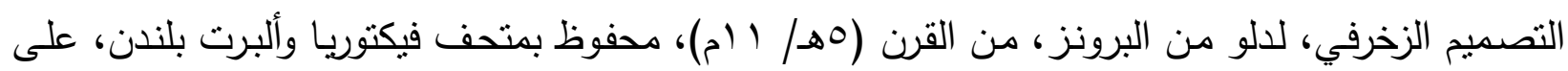

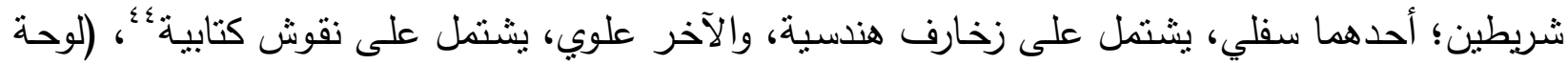

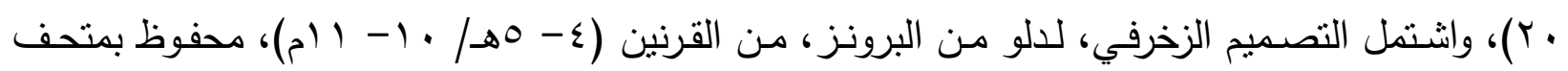

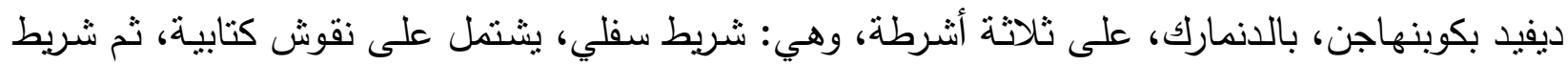

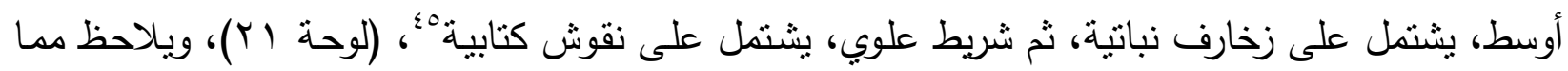

FEHÉRVÁRI, G.: Islamic Metalwork, 47, pl. 8b.

BLOOM, J.M.: Arts of the City Victorious, 98- 99, fig. 69.

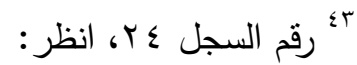

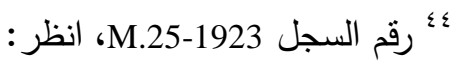

0؛ رقم السجل 87/2003، انظر : https://www.davidmus.dk/en/collections/islamic/dynasties/tulunids-and-fatimids/art/87-2003 (Accessed October 17, 2020). 
ذكر ، مدى تتوع وثراء التصميمات الزخرفية، للالاء الثلاثة (موضوع الدراسة)، وكذللك، تتوع وثراء التصميمات الزخرفية، على الدلاء الفاطمية، بوجه عام. أمـا من حيث العناصر الزخرفيـة، على الدلاء المعدنية (موضوع الدراسـة)، فيمكن تتاولها بالثشرح والتحليل، كما يلي:

\section{الزخارف النباتية: وتمتلت الزخارف النباتية، فيما يلي:}

- الزخارف النباتية المورقة المحورة (أرابيسك): وقد وجدت هذه الزخرفة، في جزئين، أسفل الثربط الكتابي،

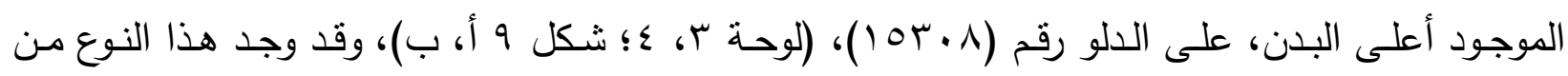

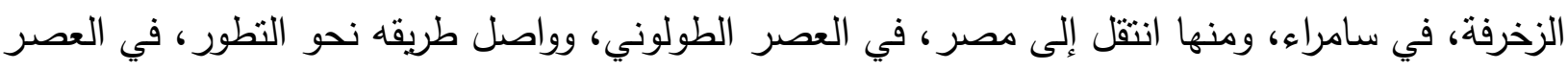

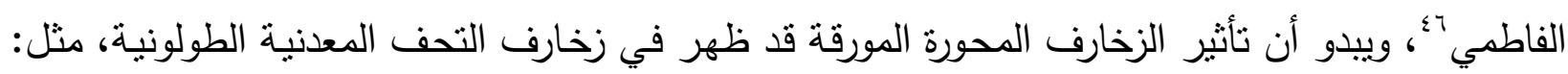

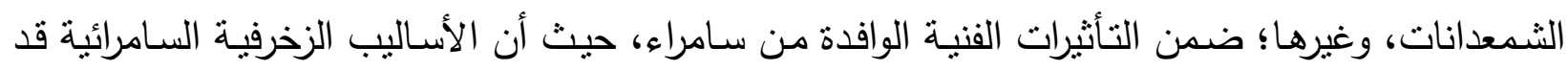

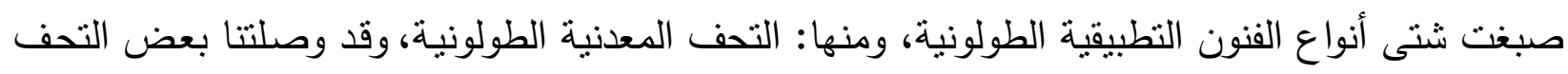
المعدنية، التي ترجع إلى مصر ، في العصر الفاطمي، وزينت بزخارف نباتيـة، حسب الأسـاليب الزخرفيـة

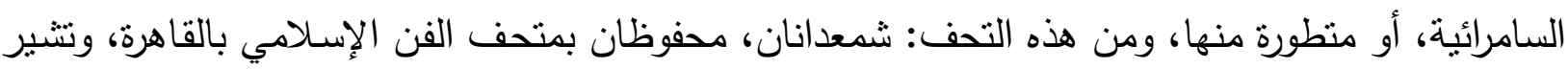

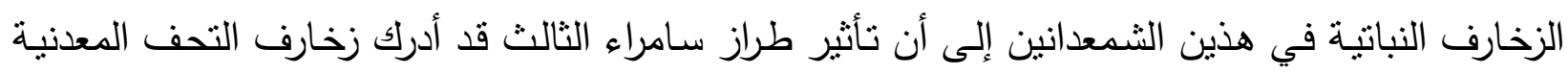

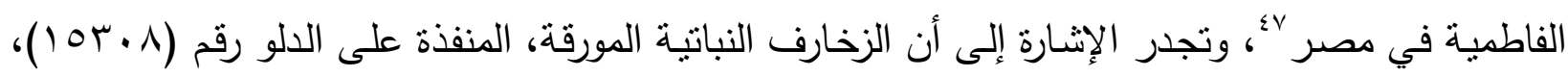

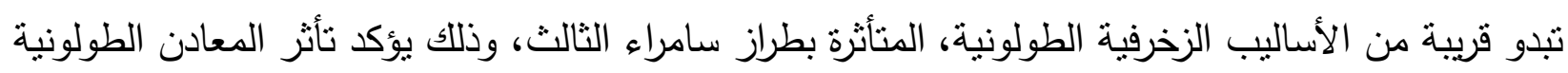

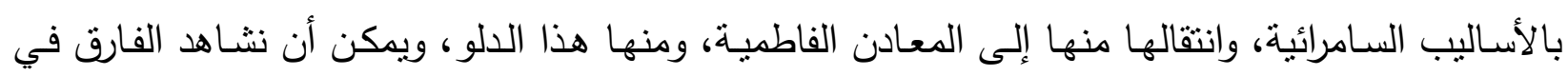

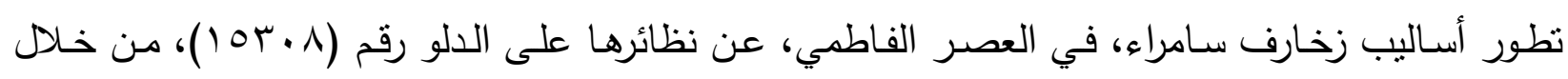

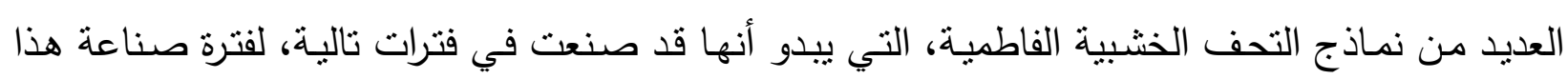

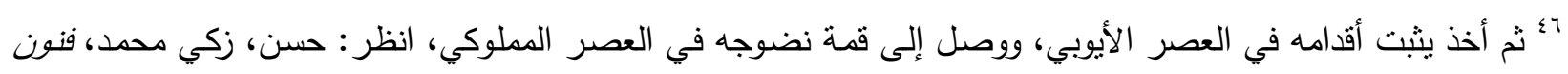

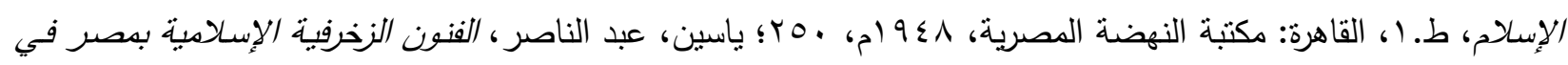

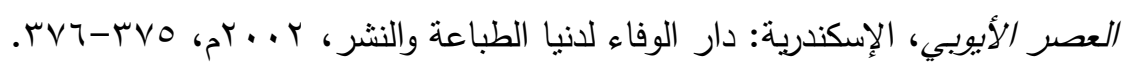

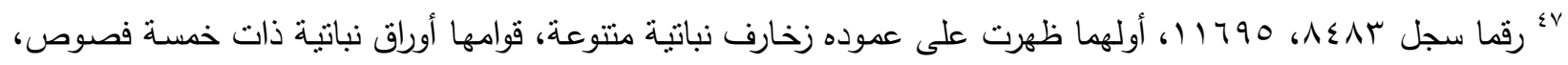

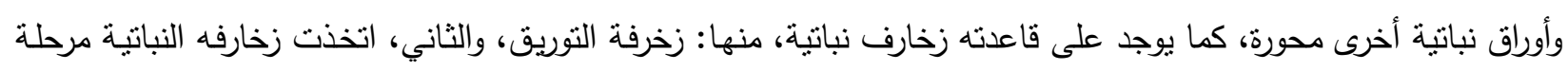

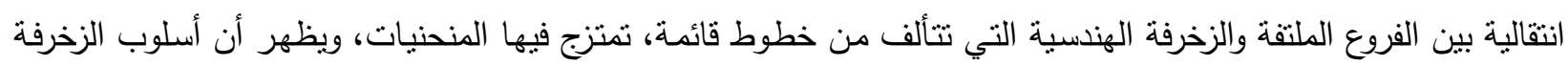

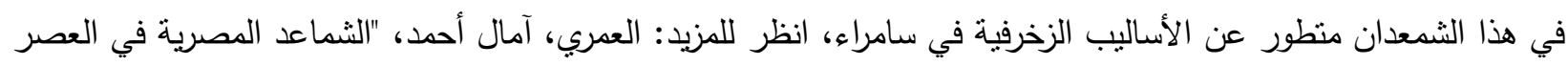

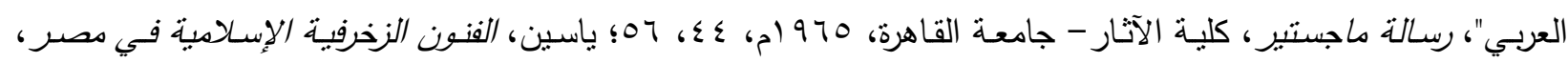

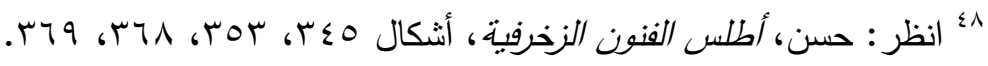


- الفرع النباتي، الأي يمتذ متماوجا، وتخرج منه سيقان نباتية صغيرة، تنتهي بأنصاف مراوح نخيلية: وقد وجد

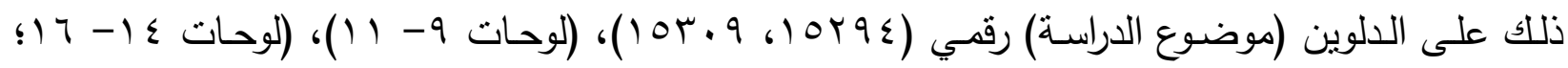
شكل · ()، وتوجد مثل هذه العناصـر، على نمـاذج أخرى، من الدلاء المعدنيـة، من صناعة مصـر، في العصر الفاطمي، ومن ذلك: دلو من البرونز، من القرنين (ع- هـ/ • ( - (ام)، محفوظ بمجموعة كير؛ حيث يوجد أعلى منتصف البدن، شريط زخرفي، يشتمل على فرع نباتي، يسبر بشكل متماوج، ويخرج منـه

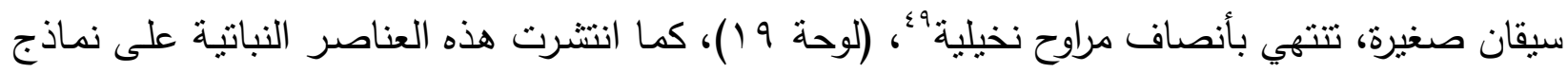
من التحف التطبيقية الأخرى، من العصر الفاطمي؛ فنجد فرعا نباتيا يمتد بشكل متماوج، وتخرج منه سيقان نباتية صغيرة، تتتهي بأنصاف مراوح نخيلية، على الجزء الداخلي من طبق من الخزف ذي البريق المعدني،

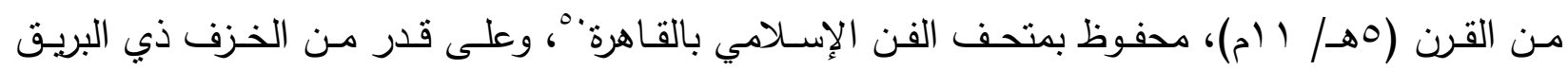

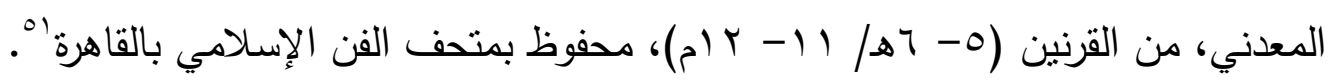
- الزخارف الهندسية: وتمثلت الزخارف الهندسية، فيما يلي: 1- عناصر هندسية، تلتف بشكل دائري، أعلى وأسفل الأشرطة الزخرفية: عبارة عن أشكال مقوسـة، أو غير منتظمة، أو خطوط منفردة ملتفة بشكل دائري، أو قد تحيط الخطوط بالأشكال المقوسة، وغير المنتظمة، من أعلى ومن أسفل، مكونة أشكال إطارات تلتف بشكل دائري، أعلى وأسفل الأشرطة الزخرفية الرئيسة، على

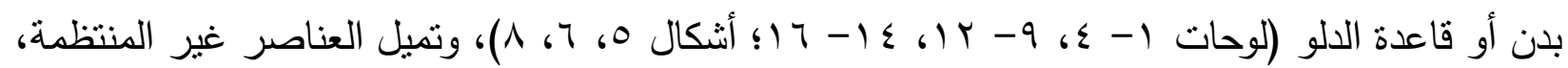
إلى البساطة، على الدلو المعدني (موضوع الدراسـة) رقم (1 • به ())، بينما تميل إلى التعقيد والإتقان، على التى

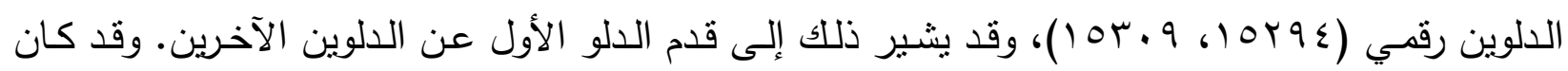
استخدام العناصر الهندسية، للفصل بين العناصر الأخرى، من أهم استخدامات الزخارف الهندية، وهو أمر مألوف على التحف التطبيقية؛ فنجد خطوطا رفيعة، تلتف بشكل دائري، أعلى وأسفل شريط زخرفي، على قدر من الخزف ذي البريق المعدني، من صناعة مصر، في العصر الفاطمي، القرنين (0- 7هـ/ (1-

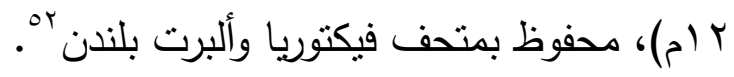
ץ- خطوط متكسرة: وقد جدت على الجزء الأفقي من حافة الدلو رقم (1 • به ))، (لوحات ؟- ^)، ونجد خطوطا منكسرة، متشابهة مع نظيرتها على الدلو المذكور، وذلك على دلو من البرونز، من صناعة مصر،

FEHÉRVÁRI, G.: Islamic Metalwork, 47, pl. 8b.

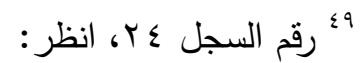

${ }^{50}$ YeOMANS, R.: the Art and Architecture of Islamic Cairo, 85.

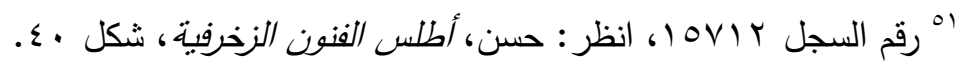
${ }^{52}$ LANE,A., early Islamic pottery Mesopotamia, Egypt and Persia, London: Faber and Faber, 1947, 21-22, pl. 24;

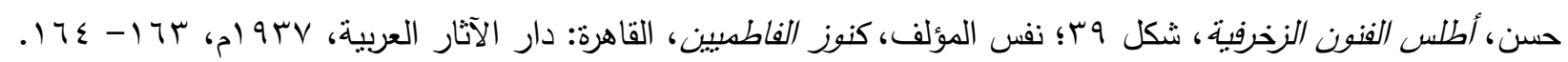




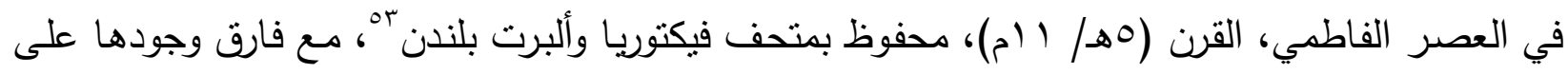
الحافة من الخارج (لوحة · †)، ووجدت الخطوط المتكسرة، ضمن الزخارف الموجودة أعلى الدعامات وبواطن

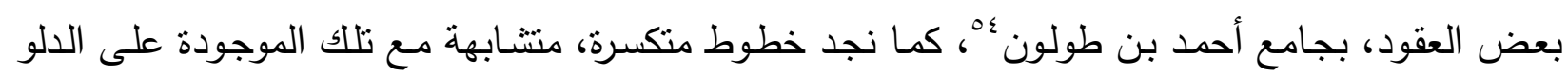

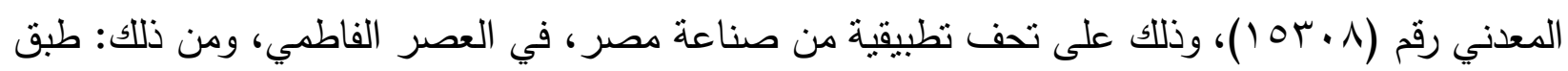

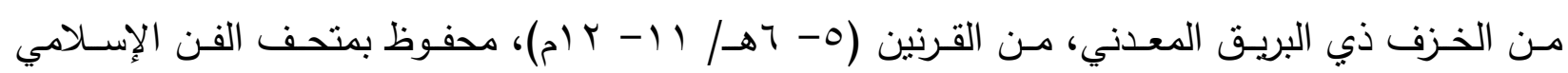

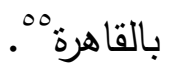

هـ مناقشـة وظيفـة هذه الدلاء: من المعلوم أن كل أداة، أو آنية تصنع من أجل غرض معين، أو أكثر،

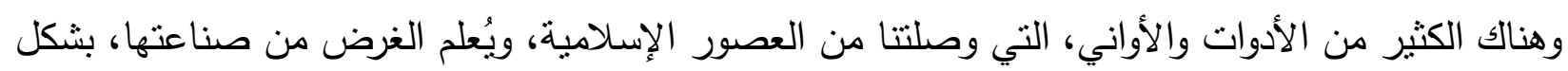

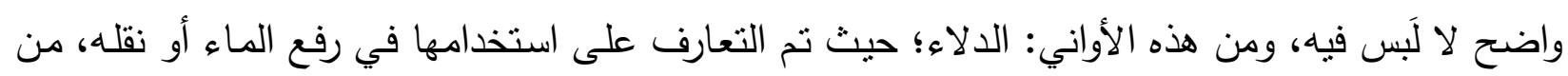

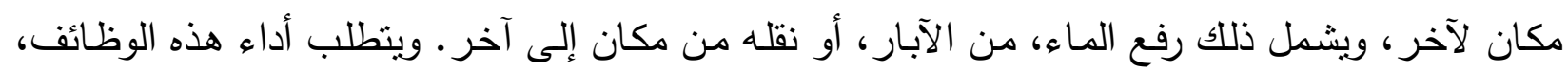

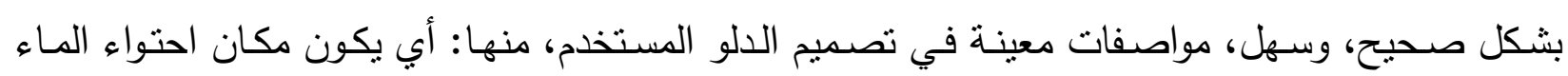

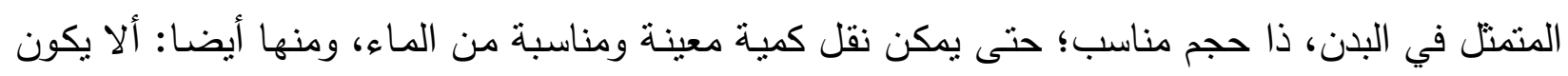

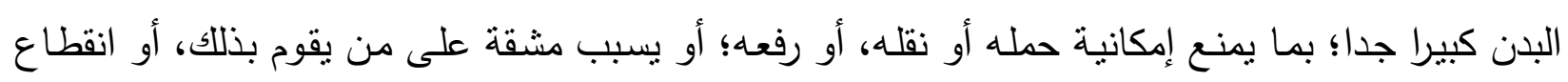

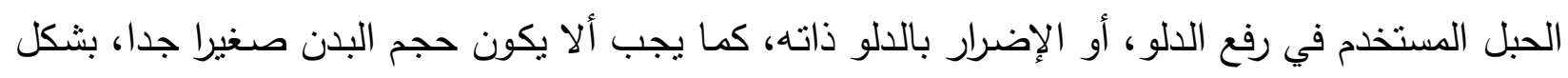

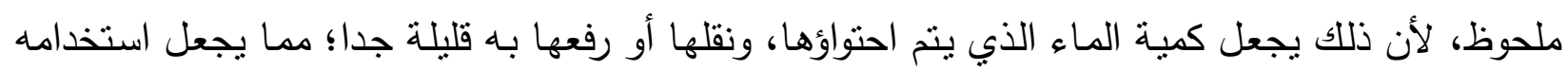

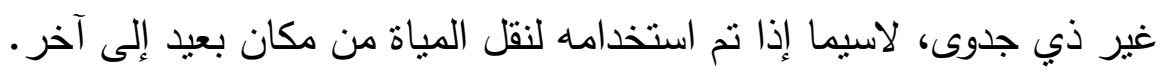

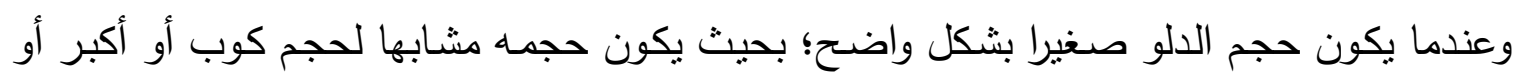

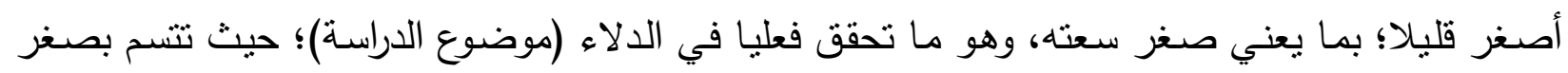

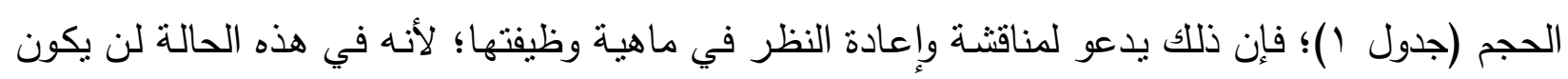

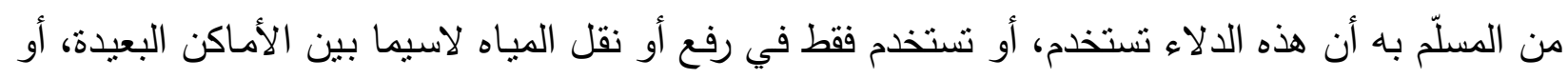

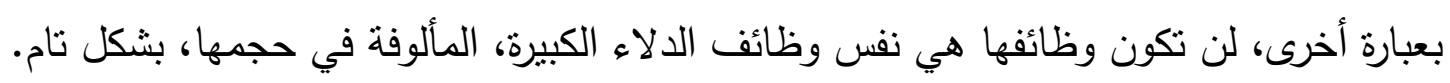

BLOOM, J.M.: Arts of the City Victorious, 98- 99, fig. 69.

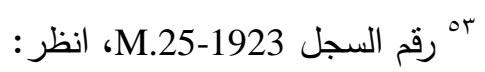

${ }^{54}$ YeOMANS, R.: the Art and Architecture of Islamic Cairo, 36, 38.

00 رقم السجل 10901 ، انظر : حسن، أطلس الفنون الزخرفية، شكل سه. 


\begin{tabular}{|c|c|c|c|c|c|c|c|}
\hline \multicolumn{6}{|c|}{ الأبعـــــــاد } & \multirow{2}{*}{ رقم } & \multirow[b]{2}{*}{ الالو } \\
\hline الارتفاع & المقبض ارتفاع & ارتفاع حلقة & حتى الارتفاع & قالفوهة & قطر البدن & & \\
\hline 11 سم & 1 سم & 0, Tr سم & • ا سم & זן سم & ז' سم & $10 r \cdot 1$ & الأول \\
\hline 11 سم & 0 سم & r سم & ل سم & Vم ل & 7 سم & $10 Y 95$ & الثاني \\
\hline غير مكتمل & مفقود & r سم & 9 سم & 0، 1 1 سم & 9 سم & 104.9 & الثالث \\
\hline
\end{tabular}

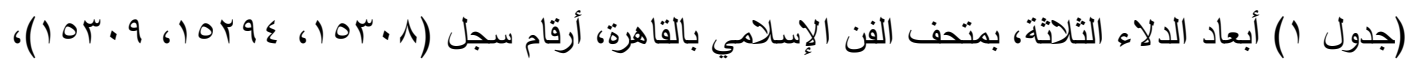
(تم قياس هذه الأبعاد بمشاركة الباحث).

وهنـاك مجموعـة مـن الاحتمـالات، التي يمكن ترجيحها ومناقتـتها، في وظـائف الدلاء (موضـوع الدراسة)، ومنها:

ه, 1ـ استخدام هذه الدلاء في رفع المـاء: من وظـائف الدلو الأساسية رفع الماء، من الآبـار، أو مـا شـابه، ويتطلب ذللك حجما مناسبا للالو، يسمح له باحتواء ورفع كمية مناسبة من الماء، في وقت مناسب. ولكن هل يمكن اسـتخدام الدلاء الثناثة (موضـوع الدراسـة)، في هذا الغرض، مـع الأخذ في الاعتبـار أن أحجامها صـغيرة، بشكل ملفت للنظـر؟ ويمكن الإجابـة على ذلك بـنع، ولعل ممـا يؤيــ ذلك: هو أحد المكونـات التصـيمة فيها، وهو وجـود مكان حلقة معدنيـة، يـربط منها حبـل التعليق، كمـا هو الحسال في الدلو رقم

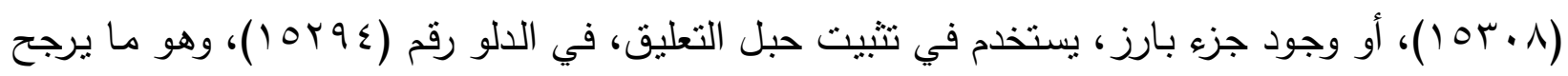
من تشـابه التصميم بشكل كبير ، أنسه كان موجودا أيضا في الدلو الآخر ، رقم (9 ، به ())، وبناء على ذلك؛ فإنه يمكن تأييد استخدام هذه الدلاء في رفع الماء، بما يتتاسب مـع حجمها مثل: استخدامها في رفع الماء، من إناء كبير، أو عميق، مثل: أواني التخزين العميقة، مثنلا، وبساعد الحبل المربوط به الدلو على ذلك. كما يمكن القول بإمكانية استخدام هذه الدلاء في رفع الماء من الآبار، أيضا، في حالات معينة، مثل: حالات

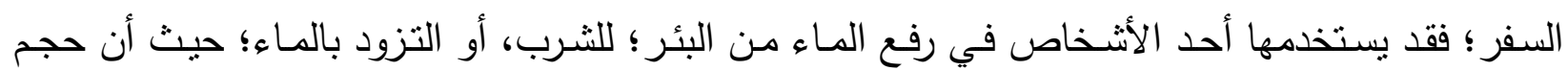
الدلو ؛ وبالتالي الكمية التي يحتويها من الماء تعتبر مناسبة للكمية التي يحتاجها هذا المسافر، وقد يساعد هذا الإناء في إمكانية عدم الترجل من على الدابة، في حالة عدم الرغبة في ذلك؛ حيث أن وجود حبل مربوط في هذا الدلو، يساعد على تحقق هذا الأمر • وقد يدخل ضمن هذا الأمر إمكانية استخدام هذه الدلاء في رفع أنواع أخرى من المواد الغذائية، مثنل: الزيوت، والخل، من الأواني كبيرة الحجم أو شديدة العمق، أو رفع هـ هُه المواد شديدة الخطورة، منل: المواد الكاوية، في المصانع، والورش، وما إلى ذلك. 


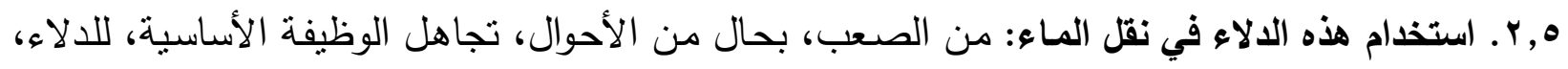

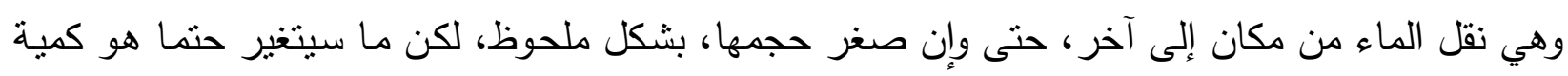

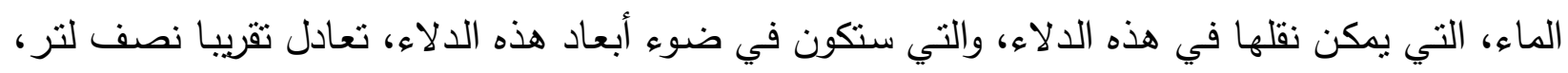
بالمعيار الحديث. وهذا بدل على إمكانية استخدام هذه الدلاء، في هذه الوظيفة، في حدود هذه الكمية، وهذا فئاء

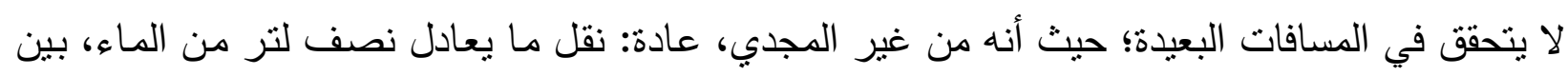

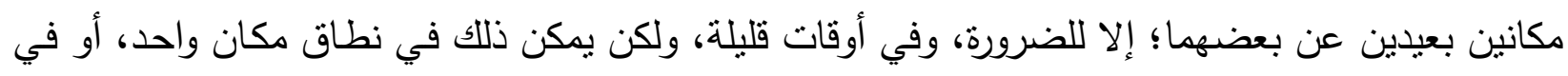

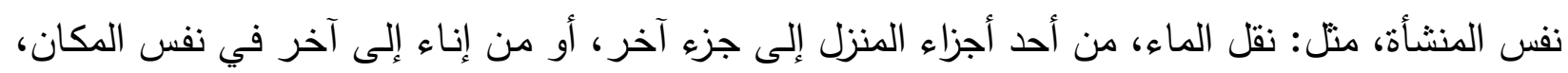

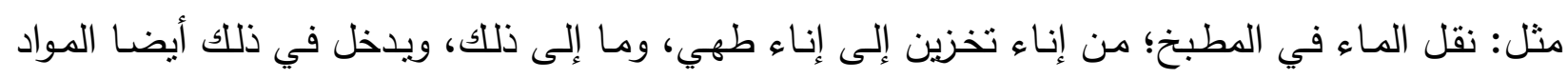
الأخرى، غير الماء.

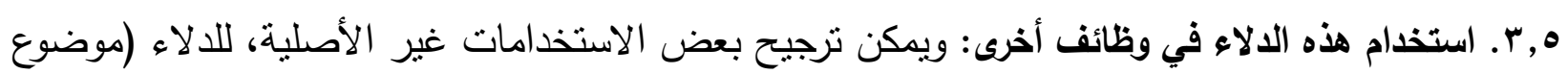

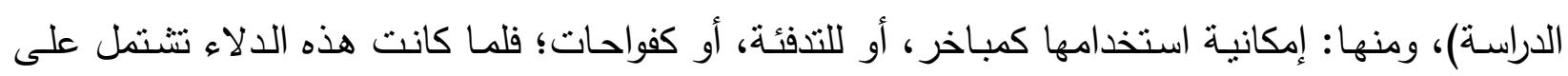

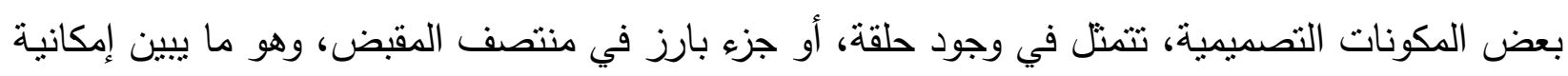

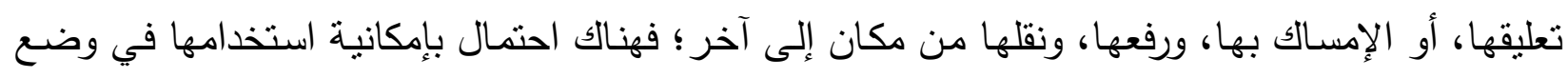

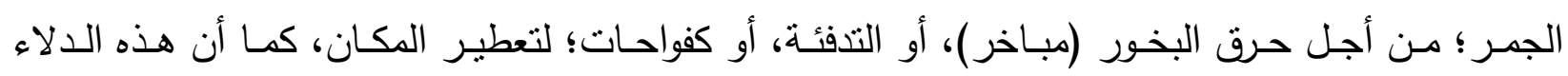

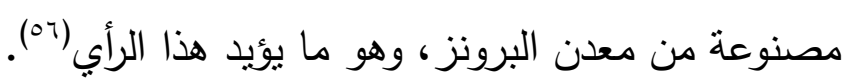
7 .التأريخ وتحديد مكان الصناعة: من خلال ما تم استعراضـه، في الدراسة التحليلية، يمكن إرجاع هذه

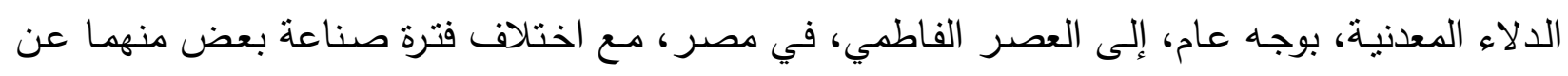

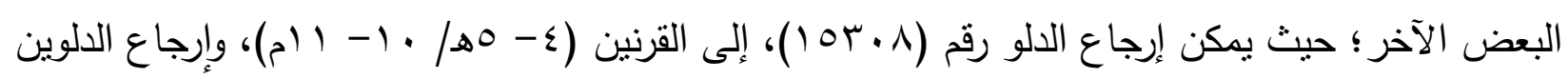

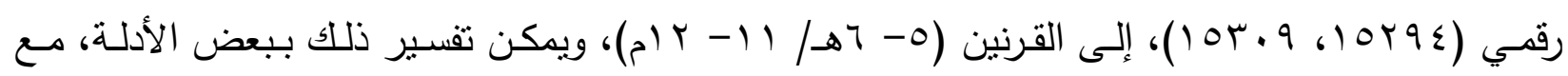
مقارنتها ببعضها البعض، وذللك كما يلي: البكا،

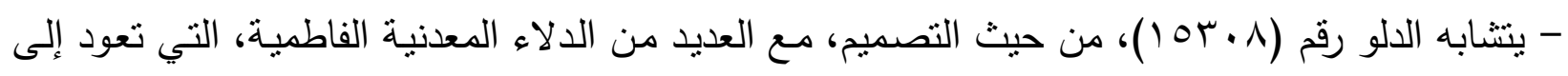

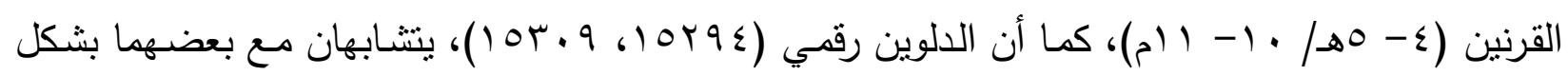
كبير، من حيث التصميم؛ مما يوحي لأول وهلة، أن هذين الدلوين متقاربين من الناحية الزمنية.

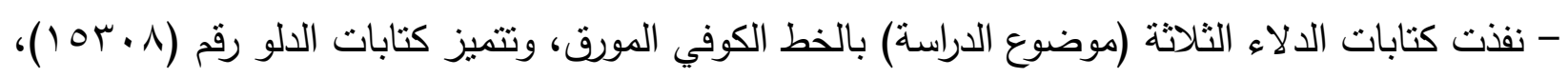

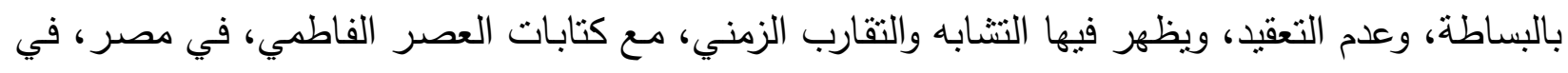

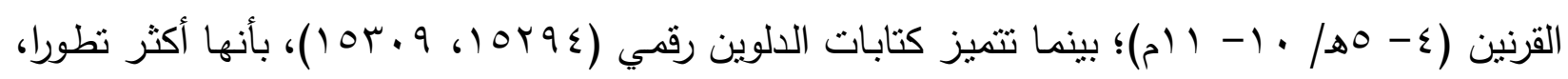

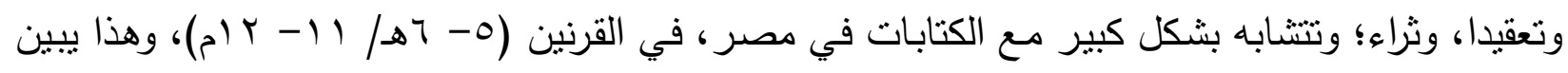

بو وقد يكون لهذه الدلاء استخدامات أخرى. 


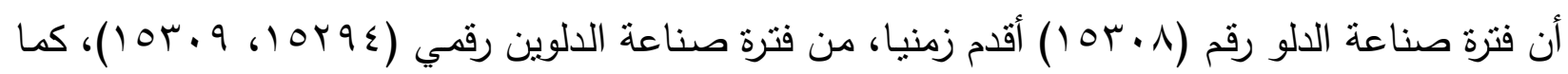

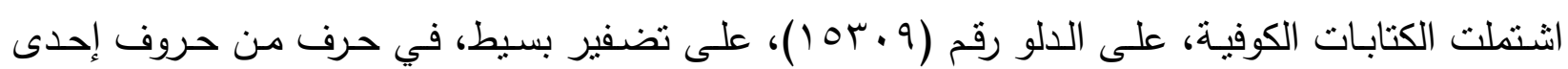
الكلمات، وهذه السمة المتمثلة في بساطة التضفير، كانت من سمات الكتابات في مصر ، في أواخر القرن

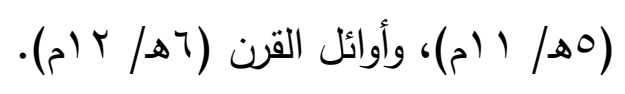

- تثابهت الكتابات، على الدلاء المعدنية الثلاثة (موضوع الدراسة)؛ سواء في مضمون الكتابات الدعائية،

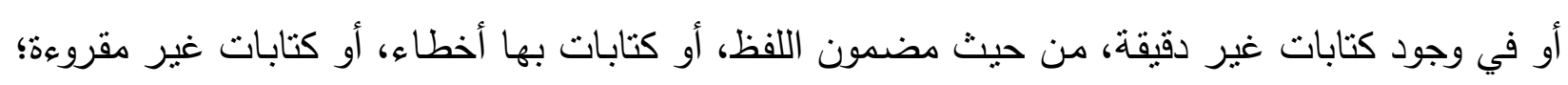
مع الكثير من نماذج الكتابات، على التحف التطبيقية، في مصرد، في العصر الفاطمي، ومنها: بعض الداء لاء المعنية. - بساطة التصميم الزخرفي على الدلو رقم (1 • به (1)، والذي يشغل جزءً بأعلى البدن فقط، مقارنة بنظيره

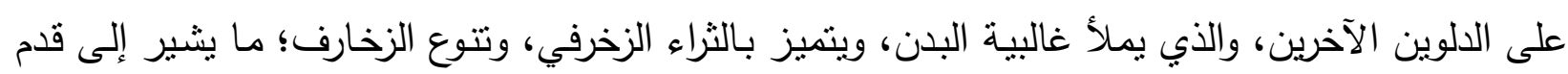
الدلو الأول، زمنيا، عن الدلوين الآخرين.

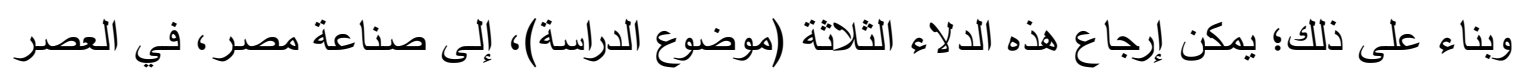

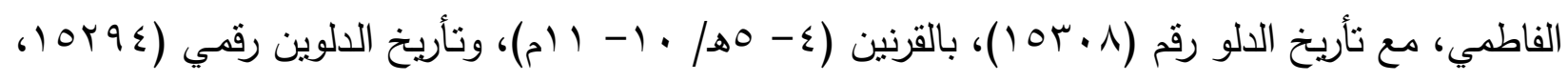

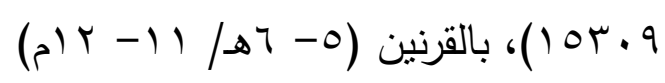
الخاتمة والنتائج: من خلال هذه الدراسة، نم استتباط النتائج التالية: - اشتملت الدلاء البرونزية (موضوع الدراسة)، على قيم وظيفية، في تصميمها، بوجه عام، وفي تصميم كل

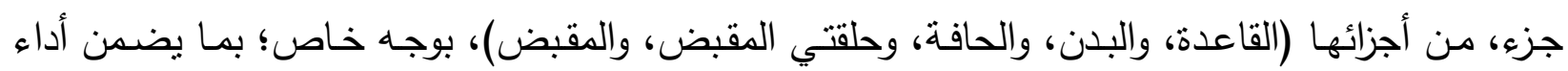

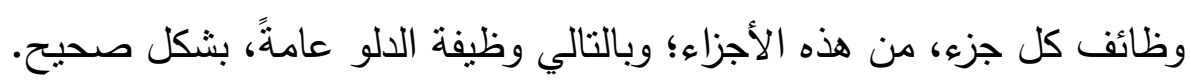
- تبين، في ضوء مجموعـة الدلاء (موضوع الدراسـة)، وجود طرازين أساسيين، من طرز تصميم الدلاء المعدنية، في مصر ، في العصر الفاطمي؛ ويتميز كل طراز منهما بمجموعة من الخصائص في مكوناته، لاسيما البدن، ومنطقة الارتكاز .

- أثتتت الدراسة، في ضوء الدلاء الثلاثة (موضوع الدراسة)، شيوع استخدام الخط الكوفي المورق، في تتفيذ

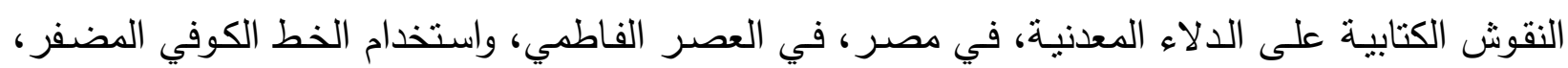
على استحياء. 
- بينت دراسة الكتابات من حيث المضمون، على الدلاء (موضوع الدراسة)، انتثار العبارات الدعائية، أكثر

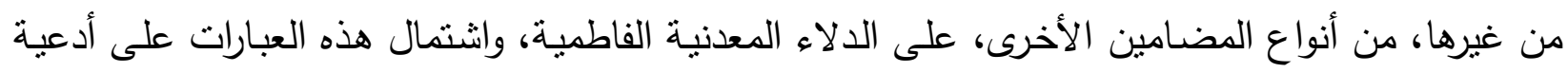
متتوعة، مثل: الدعاء بالبركة، والنعمة، والبقاء، والعافية، والغبطة.

- بينت دراسة الكتابات، على الدلاء (موضوع الدراسة)، وجود كتابات غير دقيقة، من حيث مضمون اللفظ، وكتابات بها أخطاء، وكذلك وجود كتابات غير مقروءة، وهذا يعود، في كثير من الأحيان، إلى عدم دراية الصانع بهذه الكتابات، وتقليده لها بشكل تنام. وكاه

- اشتملت الدلاء (موضوع الدراسة)، على تصميمين زخرفيين رئيسين، يتضمن كل منهما أنواعا مختلفة من

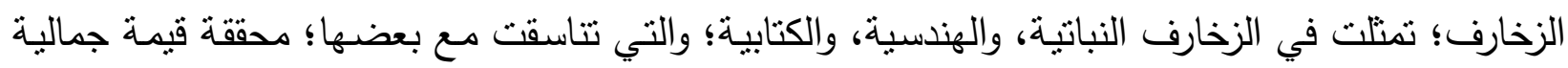
واضحة.

- من خلال مناقثة استخدامات الدلاء (موضوع الدراسة)، في ضوء أحجامها، التي تتميز بالصغر الثديد،

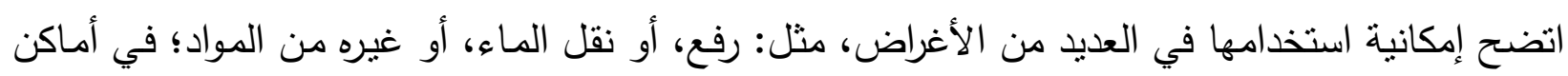
متقاربة، أو في حالات معينة، مثل السفر، أو استخدامها في أغراض أخرى غير أغران أغراضها الأساسية، مثل: استخدامها في حرق البخور (مباخر )، أو التدفئة، أو كفواحات.

- بينت الدراسة، مدى ارتباط وتأثر تصميم الآنية بوظيفتها، بشكل كبير ، وهو ما اتضح بجلاء، في تأثر أحجام هذه الدلاء بوظائفها.

- رجت الدراسة، من خلال المقارنة بالعديد من الأدلة، أن الدلاء البرونزية الثلاثة (موضوع الدراسة)، تعود

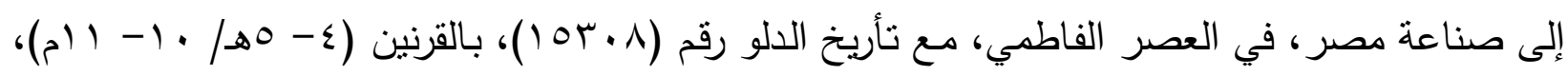

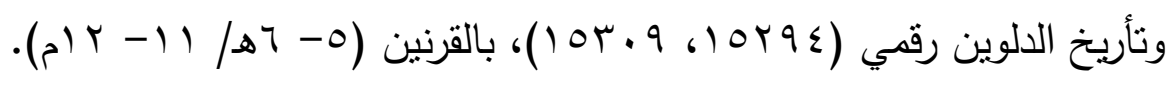




\section{ثبت المصادر والمراجع}

\section{أولاً : المراجع العربية:}

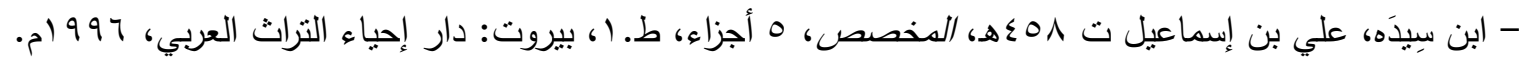
- Ibn Sīdah, 'Alī Bin 'Ismā‘î̀l, Al-muhașsạs, 5 vols., 1'st ed., Beirut: dār 'ihyā' al-turāt al-'arabī, 1996.

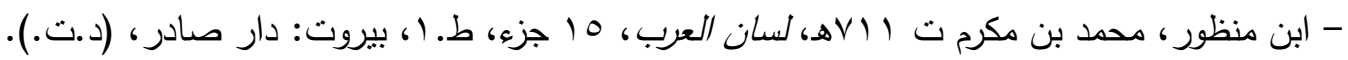

- Ibn Manẓūr, Muhammad Bin Mukarram, Lisān al- 'arab, 15 vols., $1^{\text {st }}$ ed., Beirut, dār șādir, (n.d.).

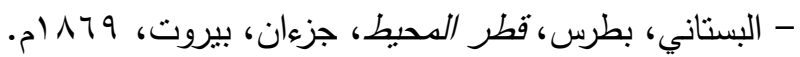

- al-Bustāni, Buṭrus, Quṭr al-muhịt, 2 vols, Beirut, 1869.

- البسطويسي، محمد السيد، "الكتابات العربية على النقود والتحف الفاطمية في مصر دراسة مقارنة"، رسالة ماجستبر ، كلية

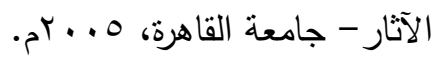

- AL-BASṬAWĪsI MUHAMMMAd, «Al-Kitābāt al- arābīya 'alā alnuqūd wa al-tuhaf al-faṭimīya fī Miṣr dirāsa muqārana», Master Thesis, Faculty of Archaeology- Cairo University, 2005.

- جمعة، إبراهيم، دراسة في تطور الكتابات الكوفية على الأحجار في مصر في القرون الخدسة الأولى للهجرة مع دراسـة

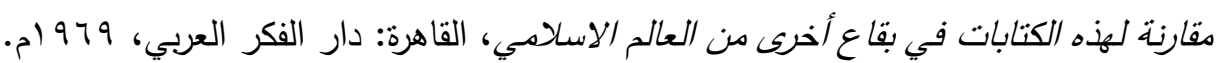

- ĞUM'A, IBRĀHIM, Dirāsa fi tațawwur al-Kitābāt al-kūfìya 'ala al-ah̆ğar fì miṣr fī al-qurūn al-hamsa al-ūla li-lhiğgra ma 'a dirāsa muqārana li-hādihi al-kitābāt fì biqāa' 'uhra min al- 'ālam al- 'islāmī, Cairo: dār al-fikr al-'arabī, 1969.

- الحبشي، حسن بن صالح، البرهان في غربب القرآن، القاهرة: مكتبة وهبة للطباعة والنشر، 991 ام.

- AL-ḤABAŠİ, ḤASAN BIN ȘĀLIḤ, Al-burhān fì ġharīb al-Qurān, Cairo: maktabat wahba lil-tiba 'a wal-našr, 1991.

- حسن، زكي محمد، كنوز الفاطعبين، القاهرة: دار الآثار العربية، وبام ام.

- Ḥasan, Zakī, Kunūz al-Fātịimiyin, Cairo: dār al-ātār al-'arābīya, 1937.

$$
\text { - حسن، زكي محمد، فنون الإسلام، ط. ا، القاهرة: مكتبة النهضة المصرية، } 9 \text { ام ام. }
$$

Funūn al- 'islām, 1st ed., Cairo: maktabat al-nahḍa al-mișrīya, 1948.

$$
\text { - حسن، زكي محمد، أطلس الفنون الزخرفية والتصاوبر الإسلامية، بيروت: دار الرائد العربي، (د.ت.). }
$$

- ḤASAN ZAKī, Ațlas al-funūn al-zuhrufìya wal-tașāwīr al-islāmīya, Beirut: dār al-ra'id al-'arabī, (n.d.).

- داود، مايسة محمود، الكتابات العربية على الآثار الإسلامبة من القرن الأول للهجرة حتى أواخر القرن الثانى عشر للهجرة

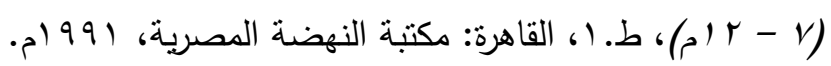

- DĀWŪD, MAYSA MuḤAMMAD, Al-kitābāt al-'arābìya 'ala al-'atâ̄r al-islāmīya min al-qarn al-awwal lil-hiğra hatta alqarn al-țānī 'ašar lil-hiğra (7-12 mīlādī), $1^{\text {st }}$ ed., Cairo: maktabat alnahụa al-mișrīya, 1991.

- رحمة، أحمد محمد، وسالم، إقبال محمد، "القيم الوظيفية والجمالية في تصميم المنتجات الجلدية وأثرها على سلوك المستهلك

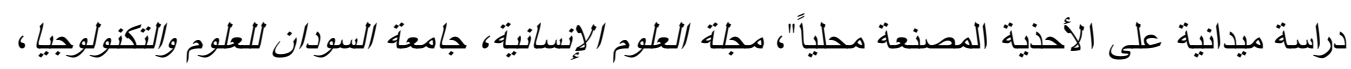

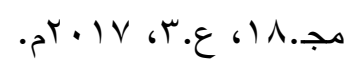

- RAḤMA, AḤMAD MuHAMMAD, \&SĀLIM, IQBĀL MuḤAMMAD, «al-Qiyam al-wazifīya wa'lğamālīya fī tașmim al-muntağāt al-ğildīya wa-ataruha 'ala sulūk al-mustahlik 
dirāsa maydānīya 'alā al-'aḥdīya al-muṣana'a maḥalīyan», Journal of Human Sciences, Sudan University of Science and Technology, vol. 18, №. 3, 2017.

- سالم، عبد العزيز صـلاح، الفنون الإسلادية في العصر الأيوبي، جـ (التحف الدعدنية)، ط. ا، القاهرة: مركز الكتاب

$$
\text { للنشر، } 999
$$

- SĀLIM, 'ABD Al-'Azīz ȘALĀḤ, Al-funūn al- 'islāmīya fì Miṣr fì al- 'aṣr al-Ayūb̄ì, vol.1, (al-tuhaf alma 'danìya), $1^{\text {st }}$ ed., Cairo: Markaz al-kitāb lil-našr, 1999.

- الثعراوي، محمد منولي، قصص الأنبياء، جمع المادة العلمية: منشاوي غانم جابر ، كتب الحواشي وراجعها: مركز التراث

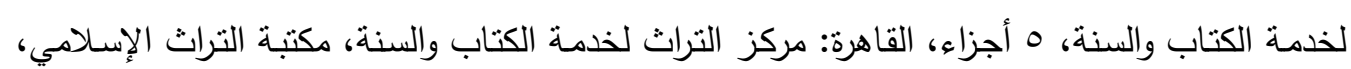

$$
\text { . } 1997
$$

- Al-ŠA'RĀWI, MuHammad Mitwalli, Qaṣaș al-anbiyā', 5 vols., Cairo: Markaz al-turāt li-hidmat al-kitāb wal-sunna, Maktabat al-turāt al-'Islāmī, 1996.

$$
\text { - الشماع، شذى معيوف، الآلة والأداة في التعبير القرآني، بيروت: دار الكتب العلمية، } 9 \text {. . بم. }
$$

- AL-ŠAMMĀ', ŠADA MA 'YŪF, al-Ala wa'l-'adāh fī al-ta 'bīr al-Qur'ānī, Beirut: Dār al-kutub al'ilmīya, 2009.

- عبد الوهاب، حسن، تاريخ العساجد الأثرية، جزءان، سلسلة ذاكرة الكتابـة (هو ()، القاهرة: الهيئة العامـة لقصور الثقافة،

$$
\cdot{ }^{2}+1 \leqslant
$$

- 'Abd al-Wahhāb, Ḥasan, Tārih̆ al-masāŏgid al-atarīya, 2 vols., Cairo: al-Hay'a al-'āmma li-quṣūr taqāfa, 2014.

- عدلي، هناء محمد، "التماثيل في الفن الاسلامي في الفترة من صدر الإسلام حتى نهاية القرن التاسع الهجري الخامس عشر

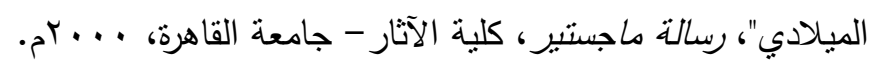

- 'ADLİ̀, ḤANĀ' MUHAMMAD, «al-Tamātịl fī al-fan al-'islāmī fī al-fatra min șadr a al-'Islām hatta nihāyat al-qarn al-tāsi' al-Hiğrī al-hāmis 'ašar al-Mīlādī», Master Thesis, Faculty of Archaeology- Cairo University, 2000.

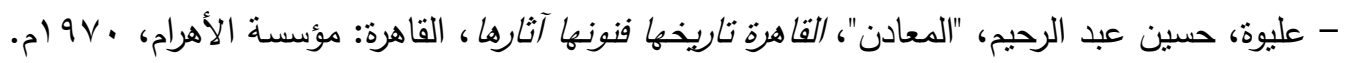

- 'IlīWA, ḤUSĪN 'ABD AL-RAḤ̄M, «Al-ma'ādin», in: al-Qāhira tārihuhu funūnuha ātāruha, Cairo, 1970.

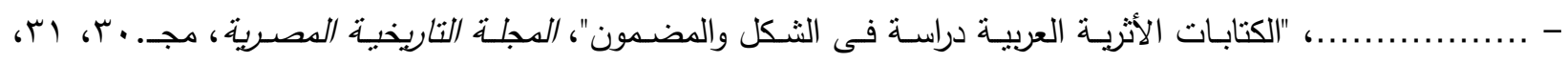

$$
\text { . } 191 \varepsilon \text { ، } 1914
$$

"Al-Kitābāt al-'atarīya al-'arābīya dirāsa fī al-šakl wa-al-maḍmūn", al-măgalla al-tārīhìya al-mișrīya 30\&31, 1983\&1984.

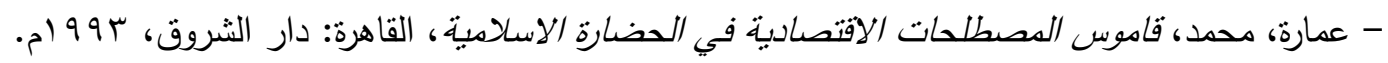

- 'IMĀRA, MuḤAMMAD, Qamus al-muștalahāat al-'iqtiṣādìya fì al-ḥaḍara al-'islāmīya, Cairo: Dār alšurūq, 1993.

- العمري، آمال أحمد، "الثماعد المصرية في العصر العربي"، رسالة ماجستبر، كلية الآثار - جامعة القاهرة، 970 ام.

- AL-'IMARĪ, AMĀL AHMAD, «al-šamā id al-mișrīya fī al-'așr al-'arābī», Master Thesis, Faculty of Archaeology- Cairo University, 1965.

- لوكاس، ألفريد، المواد والصناعات عند قدماء المصربين، ترجمة: زكي اسكندر، محمد زكريا غنيم، ط. ا، القاهرة: مكتبة

$$
\text { مدبولي، } 991 \text { ام. }
$$

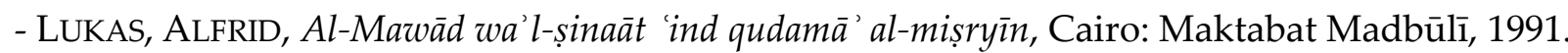

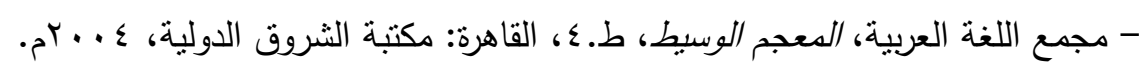

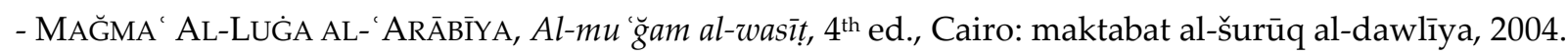


- مصيلحي، سعيد محمد، "أدوات وأوانى المطبخ المعدنية في العصر المملوكي درسة أثرية فنية"، رسالة دكتوراه، كلبة الآثار -

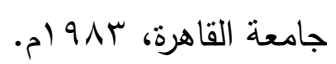

- MișiLḤ̄, SA'ĪD MUHAMMAD, «Adawāt wa 'awānī al-matbah̆ al-ma'danīya fī al-'așr al-mamlūkī dirāsa 'atarīya fannīya», PhD Thesis, Faculty of Archaeology- Cairo University, 1983.

$$
\text { - المهدي، عنايات، فن أشغال المعادن والصباغة، القاهرة: مكتبة ابن سينا، ع9 } 9 \text { ام. }
$$

- Al-Mahdi, 'Inayāt, Fann ašğāl al-ma 'ādin wa'l-ṣiyāgàa, Cairo: Maktabat ibn Sīna, 1994.

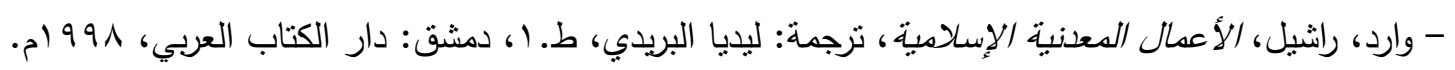

- WARD, RACHEL, al-A 'māl al-ma 'danīya al-'islāmìya, 1'st ed., Damascus: Dār al-kitāb al- arabī, 1998.

- ياسين، عبد الناصر ، الفنون الزخرفية الإسلامية بعصر في العصر الأيوبي، الإسكندرية: دار الوفاء لدنيا الطباعة والنشر ،

$$
\cdot r+r
$$

- YĀSīn, 'ABD Al-NĀṣIR, Al-funūn al-zuhrufìya al-islāmīya bimișr fì al- 'aṣr al-Ayūbì, 1st ed., Alexandria: Dār al-wafā' li-dunya al-țibā'a wa'l-našr, 2002.

$$
\begin{aligned}
& \text { ،. الفنون الزخرفية الإسلامبية في مصر منذ الفتح الإسلامي حتى نهاية العصر الفاطمي (دراستة آثارية }
\end{aligned}
$$

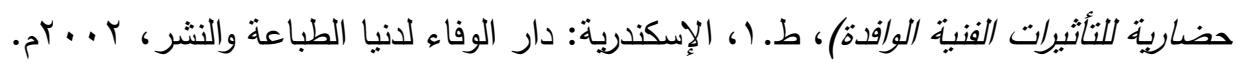

al-Funūn al-zuhrufìya al-'islāmìya fì Mișr mundu al-fath al-islāmī hatta nihāyat al-'așr al-

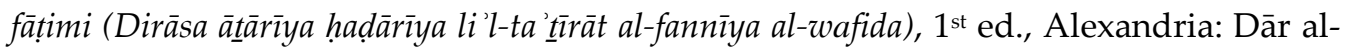
wafā' li-dunia al-țibā'a wa'l-našr, 2002.

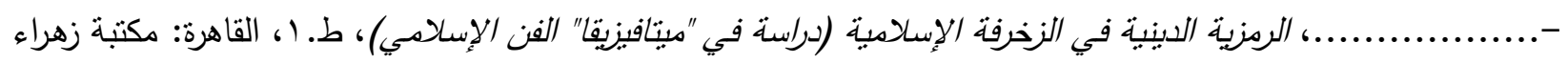

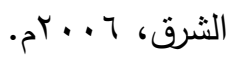

al-Ramzìya al-dīnīya fì al-zahrafa al-islāmīya (Dirāsa fi "mitafiziqa" al-fan), $1^{\text {st }}$ ed., Cairo: Maktabat zahrā’ al-šarq, 2006.

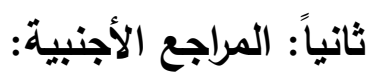

- Bloom, J.M.: Arts of the City Victorious: Islamic Art and Architecture in Fatimid North Africa and Egypt, London and New Haven: Yale University Press, 2007.

- BURCKHARDT, T.: Art of Islam Language and Meaning Commemorative Edition, Bloomington, Indiana: World Wisdom, 2009.

-DAVIS, J.R.: Copper and Copper Alloys, ASM Specialty Handbook, USA: AMS international, 2001.

- FEHÉRVÁRI, G.: Islamic Metalwork of the Eighth to the Fifteenth Century in the Keir Collection, $1^{\text {st }}$ ed., London: Faber and Faber Limited, 1976.

- GrohmanN, A.: «The Origin and Early Development of Floriated Kūfic», Ars Orientalis 2, 1957.

- HiLlenBRAND, R., Islamic Art and Architecture, London: Thames and Hudson, 1999.

- JENKINS, M.: «Muslim: An Early Fatimid Ceramist», the Metropolitan Museum of Art Bulletin 26, №. 9, 1968. doi: $10.2307 / 3258401$.

- JenKINS, M.: «Early Medieval Islamic Pottery: The Eleventh Century Reconsidered», Muqarnas 9, 1992. doi: $10.2307 / 1523135$.

- LANE, A.: early Islamic pottery Mesopotamia, Egypt and Persia, London: Faber and Faber, 1947.

- YeOMANS, R., the Art and Architecture of Islamic Cairo, $1^{\text {st }}$ ed., Lebanon: Garnet Publishing Limited, 2006.

- ZAHNER, L.W., Copper, Brass, and Bronze Surfaces: A Guide to Alloys, Finishes, Fabrication and Maintenance in Architecture and Art, Hoboken \& New Jersey: John Wiley \& Sons, 2020.

ثالثا: الثبكة الدولية للمعلومات:

https://www.davidmus.dk/en/collections/islamic/dynasties/tulunids-and-fatimids/art/87-2003 (Accessed October 17, 2020).

http://media.vam.ac.uk/collections/img/2006/AT/2006AT3744_2500.jpg (Accessed October 10, 2020). 


\section{اللوحات والأثكال التوضيحية}

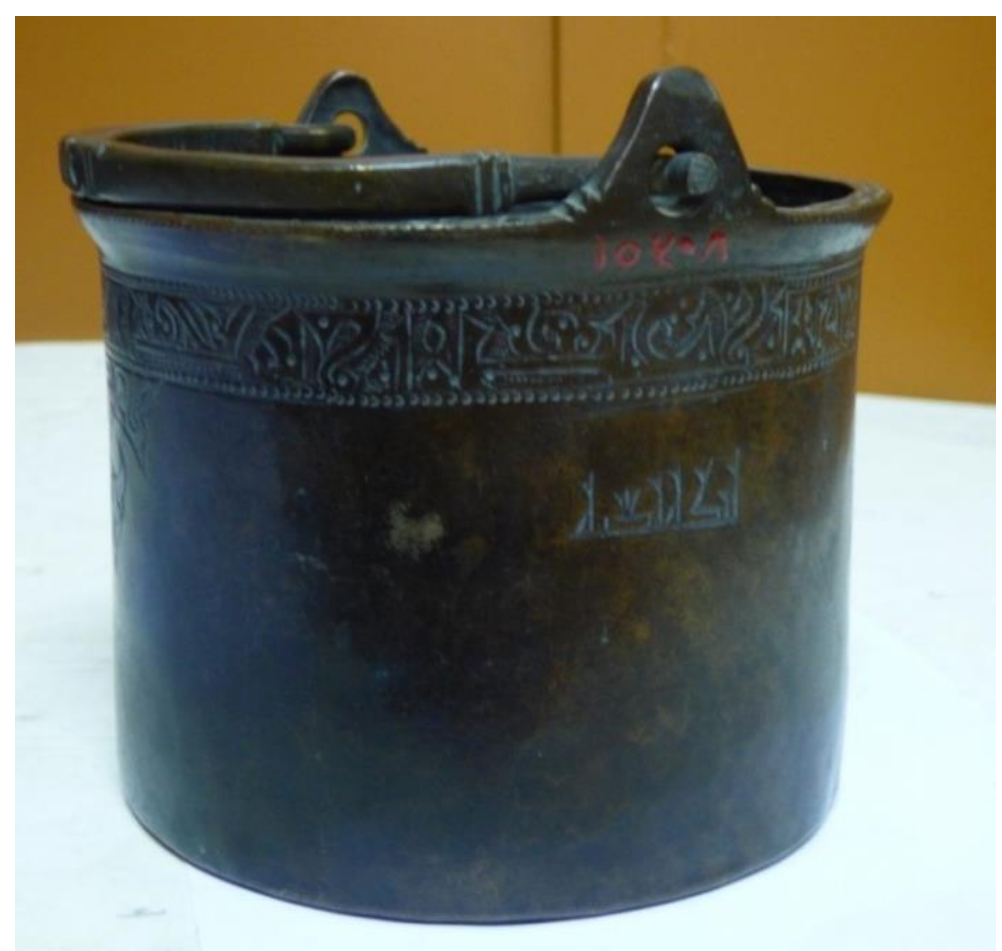

(لوحة ( ) دلو من البرونز ، يرجح نسبته إلى صناعة مصر ، في العصر الفاطمي، القرنين (ع- مهـ/ • ا-

(1)، محفوظ بمتحف الفن الإسلامي بالقاهرة، رقم السجل (1 • rه1)، ينشر لأول مرة،

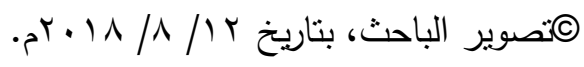

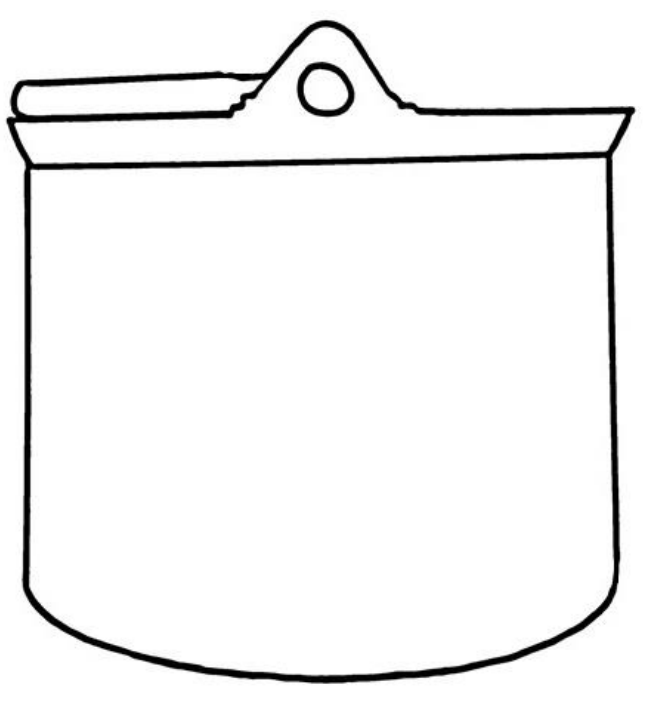

(شكل ()): تصميم الدلو البرونزي، رقم

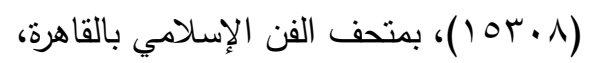
جمن عمل الباحث.

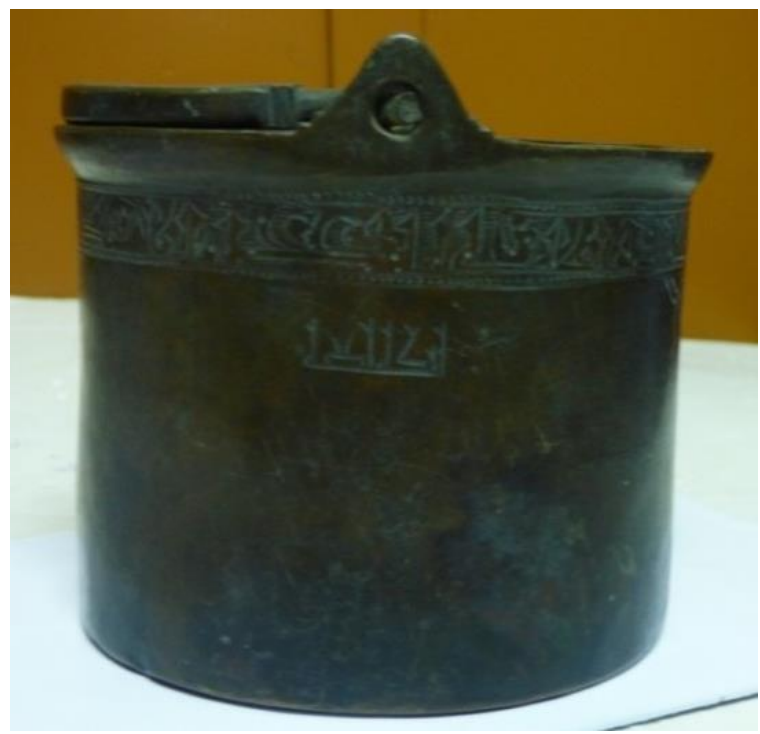

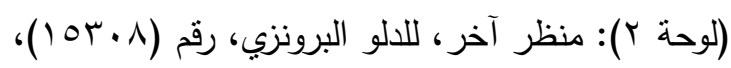
بمتحف الفن الإسلامي بالقاهرة،

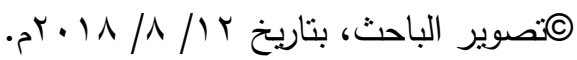




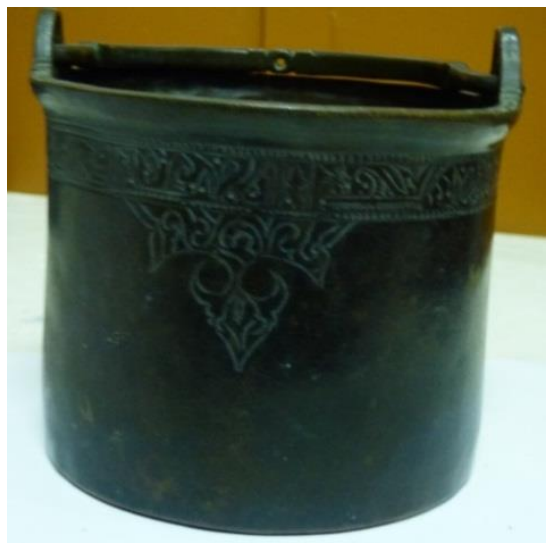

(لوحة §): بعض زخارف الدلو البرونزي، رقم

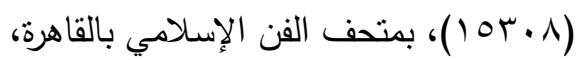

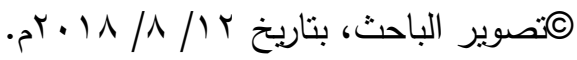

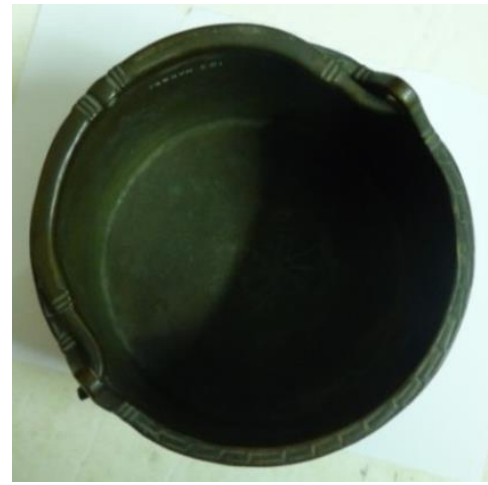

(لوحة ؟) منظر علوي للالو البرونزي، رقم

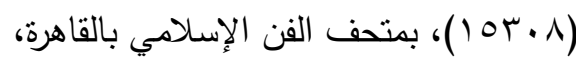

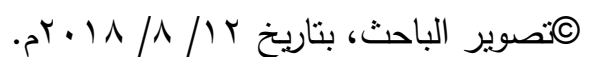

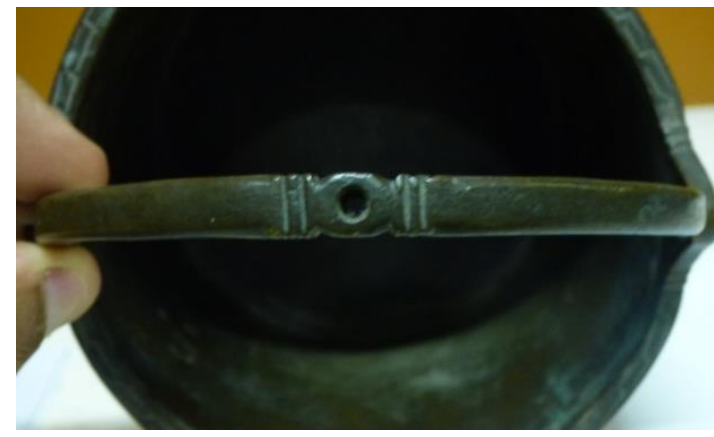

(لوحة ^) منظر لمقبض الدلو البرونزي، رقم

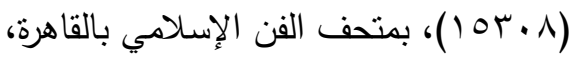

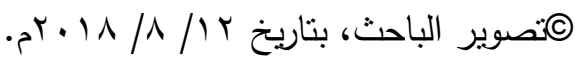

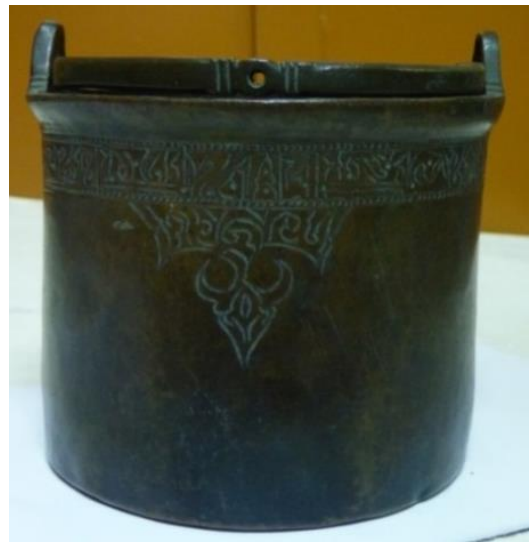

(لوحة r): بعض زخارف الدلو البرونزي، رقم

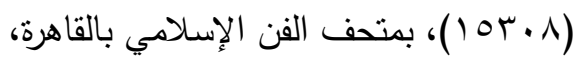

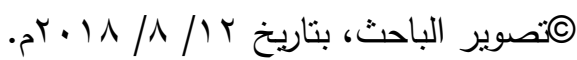

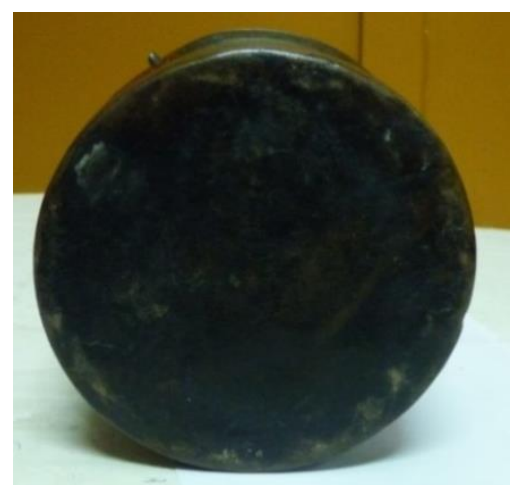

(لوحة 0) منظر لقاع البدن، في الدلو البرونزي، رقم

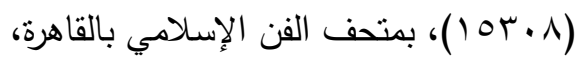

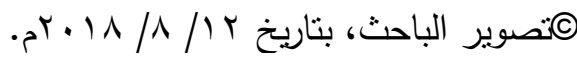

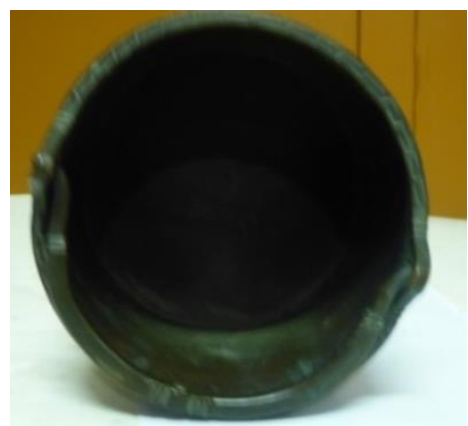

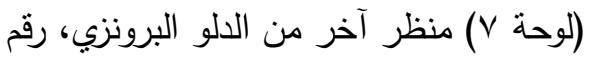

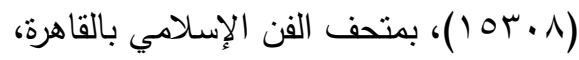

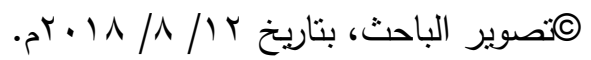




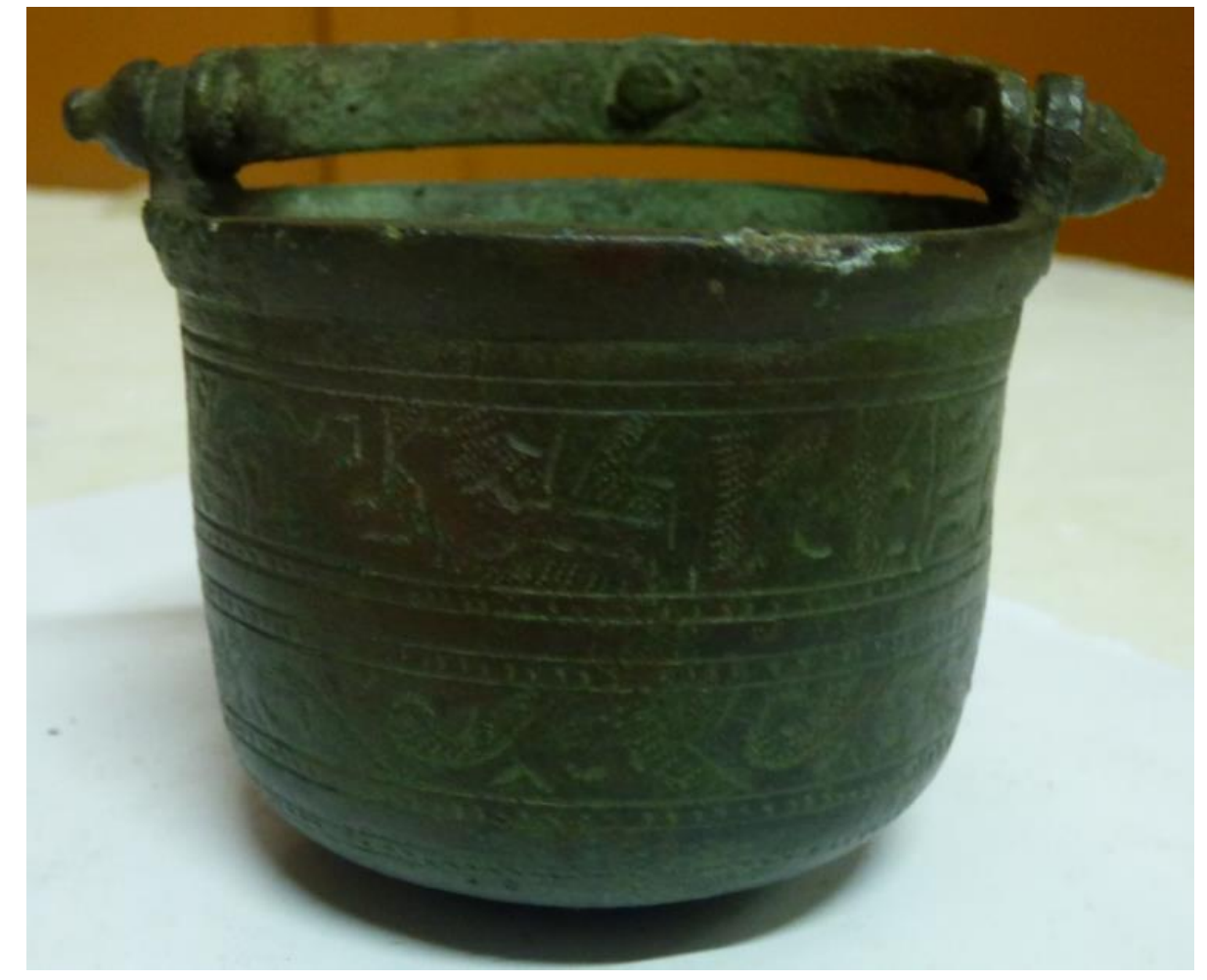

(لوحة 9) دلو من البرونز، يرجح نسبته إلى صناعة مصر ، في العصر الفاطمي، القرنين (0- 7هـ/ (1)

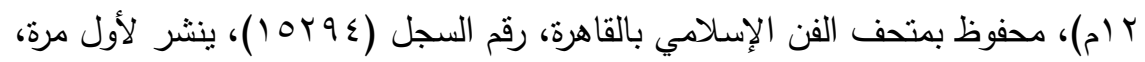

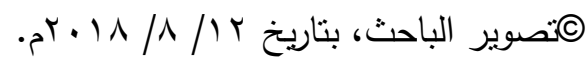
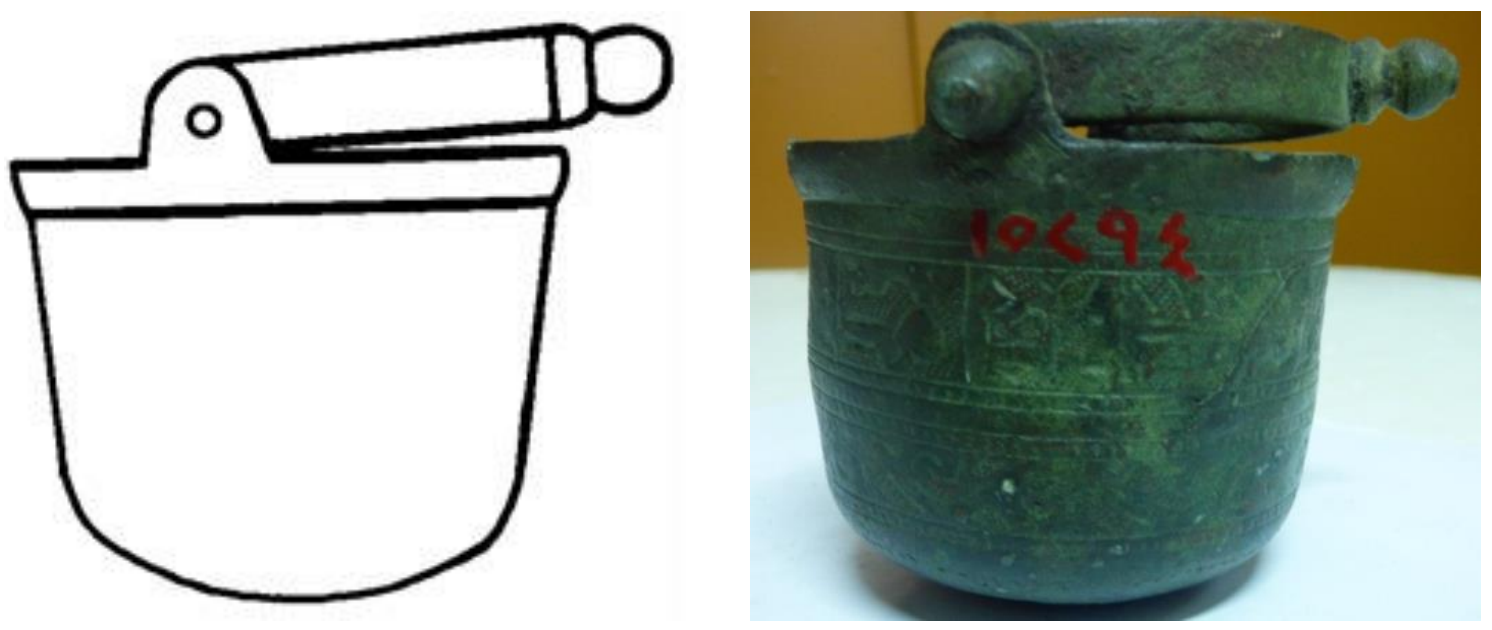

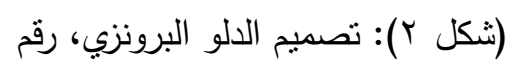

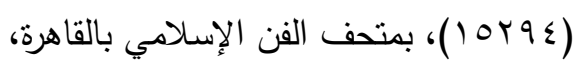

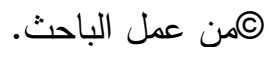

(لوحة • (1): منظر آخر ، للالو البرونزي، رقم

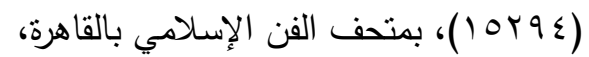

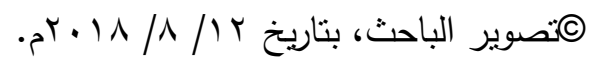




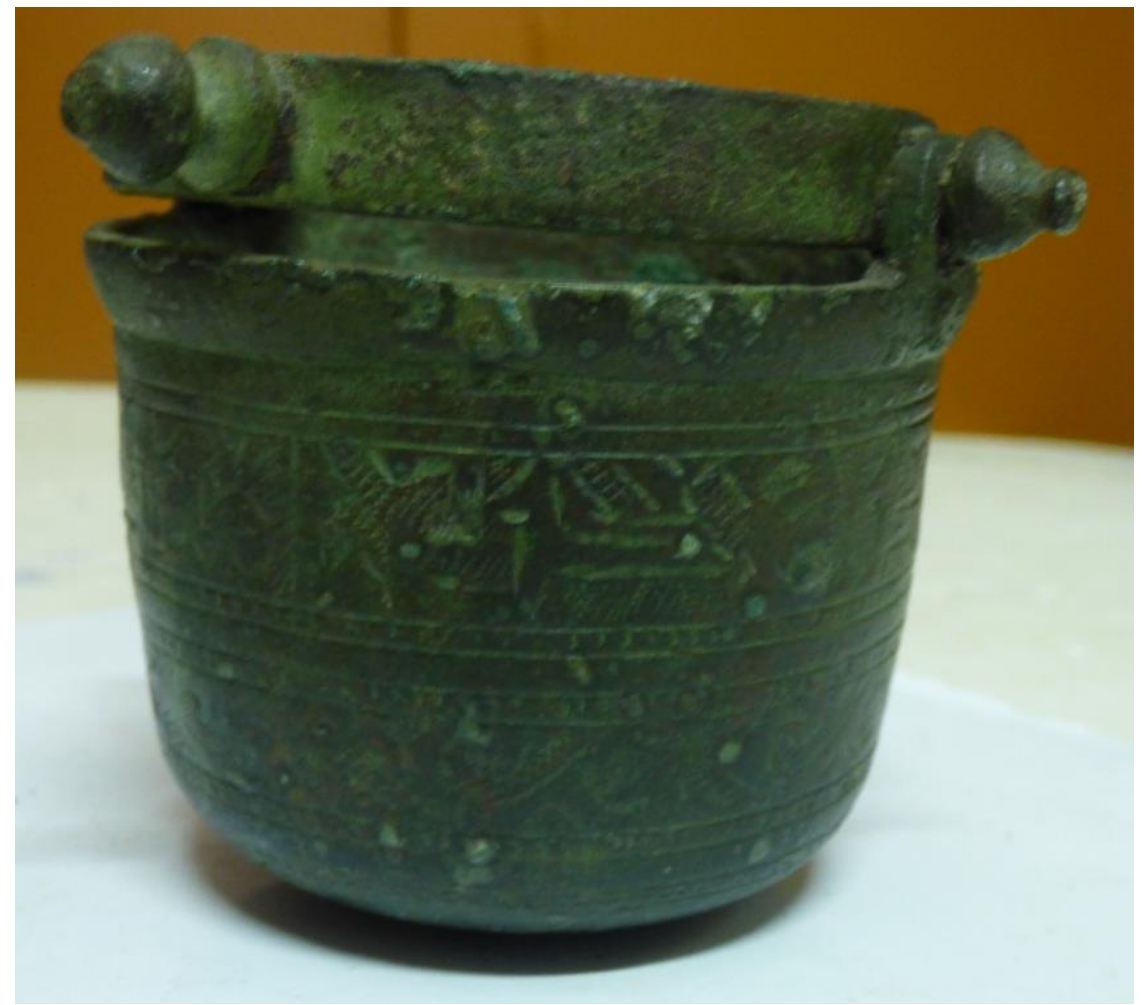

(لوحة (1) منظر آخر، للالو البرونزي، رقم (ـ9 9 (1))، بمتحف الفن الإسلامي بالقاهرة،

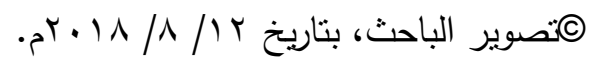

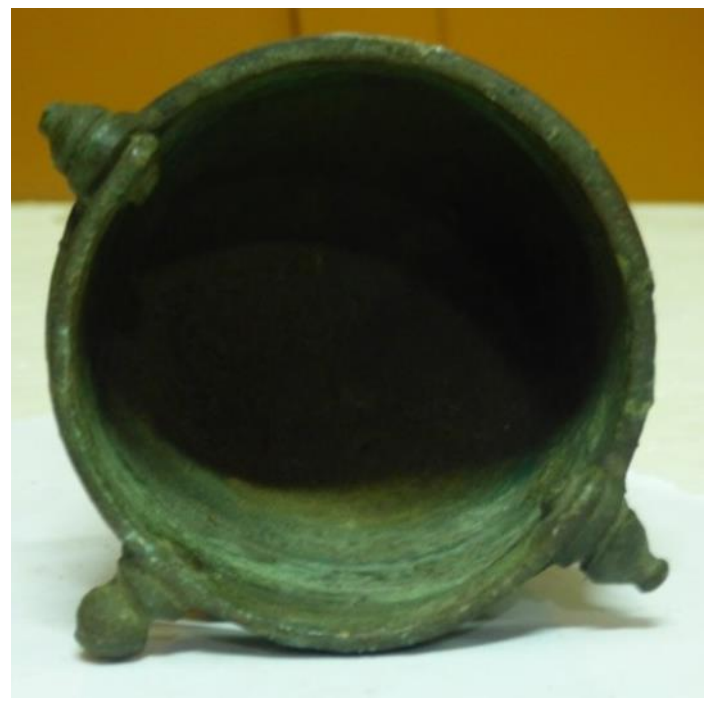

(لوحة r ا): منظر علوي، للالو البرونزي، رقم

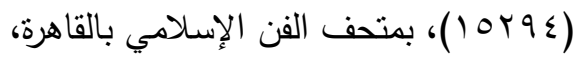

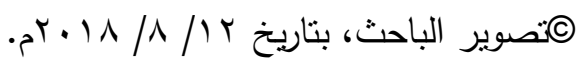

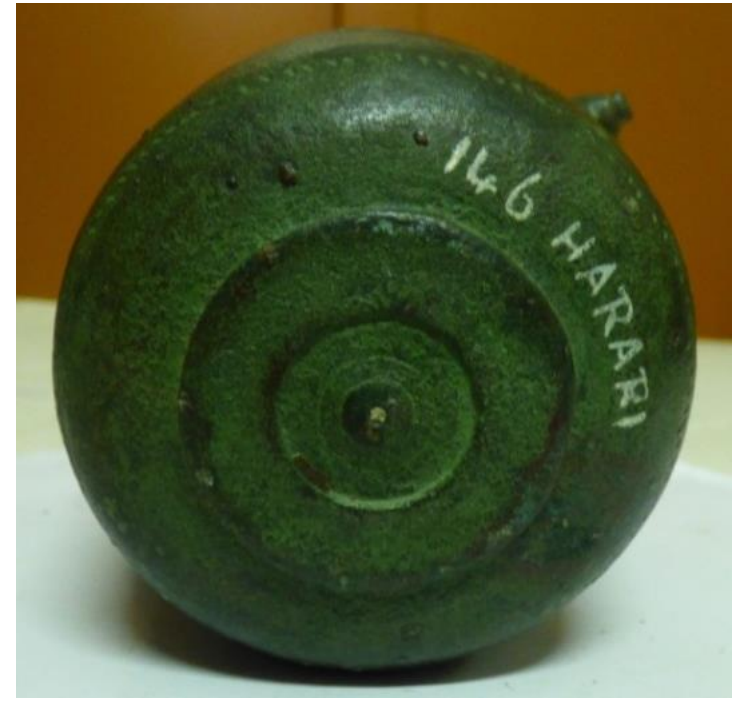

(لوحة r ا ): منظر لقاعدة الدلو البرونزي، رقم

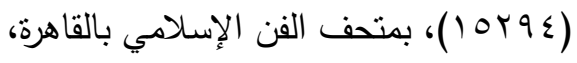

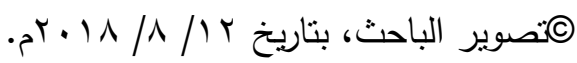




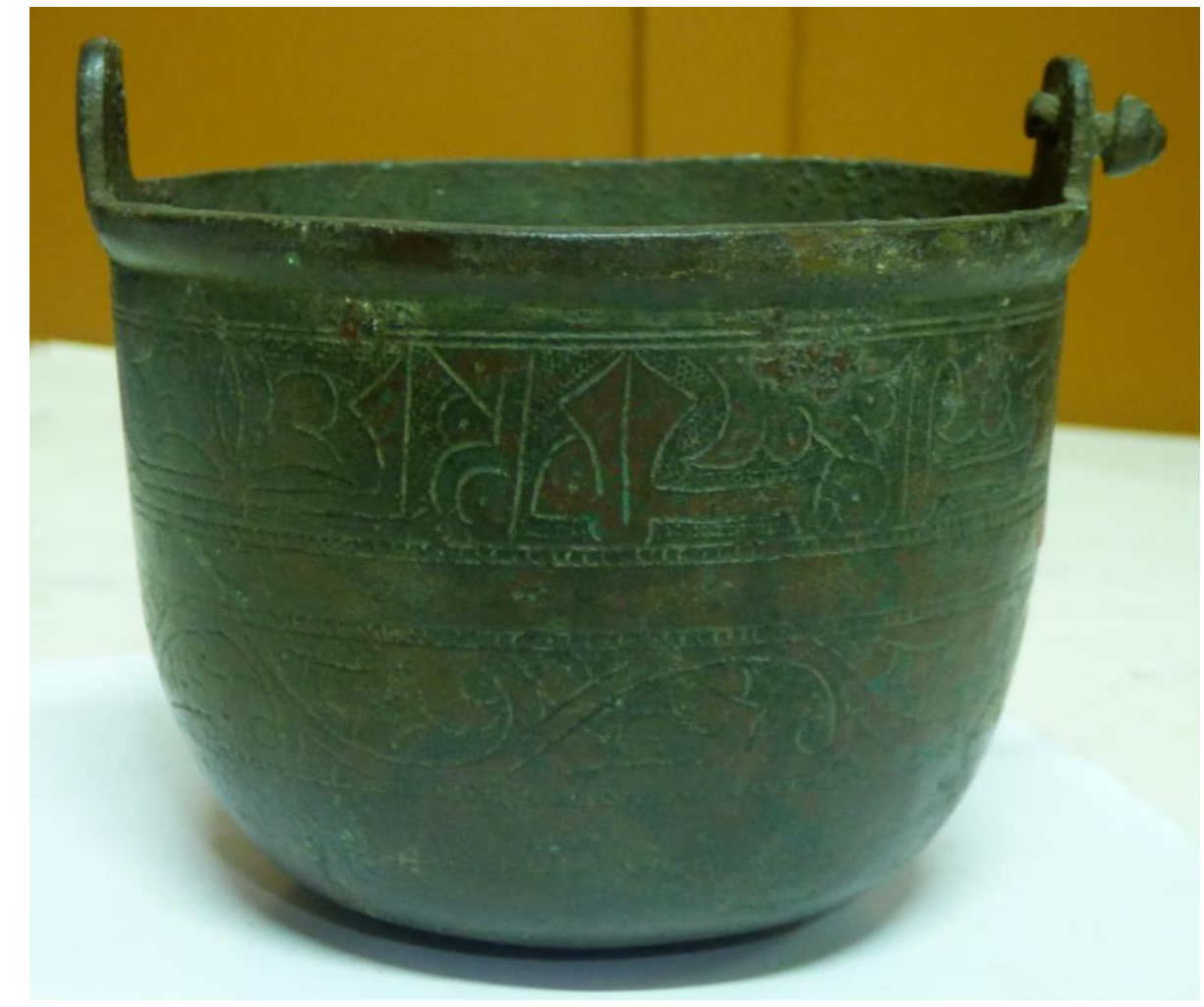

(لوحة § () دلو من البرونز، يرجح نسبته إلى صناعة مصر ، في العصر الفاطمي، القرنين (0- 7 هـ/ (1)

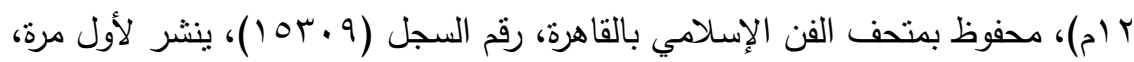

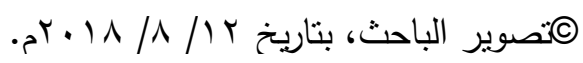

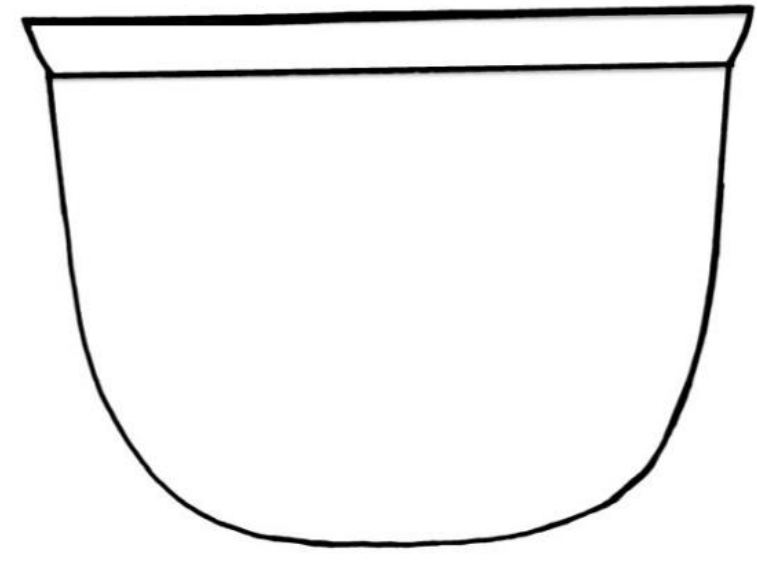

(شكل r): تصميم البدن والحافة، في الالو البرونزي،

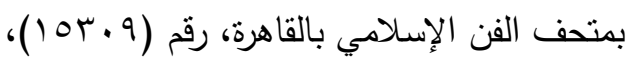
(من عمل الباحث).

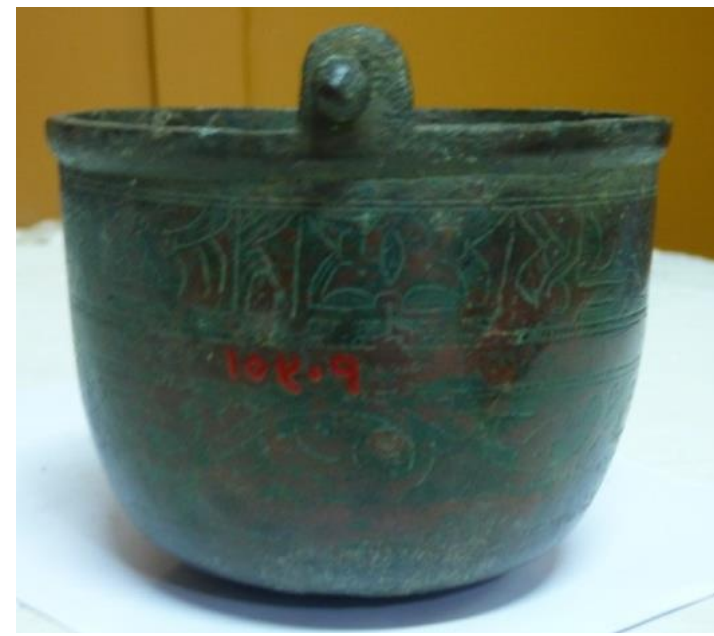

(لوحة 0 (1): منظر آخر، للالو البرونزي، رقم

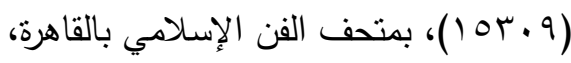

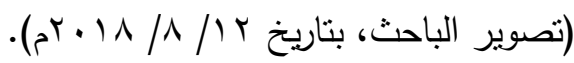




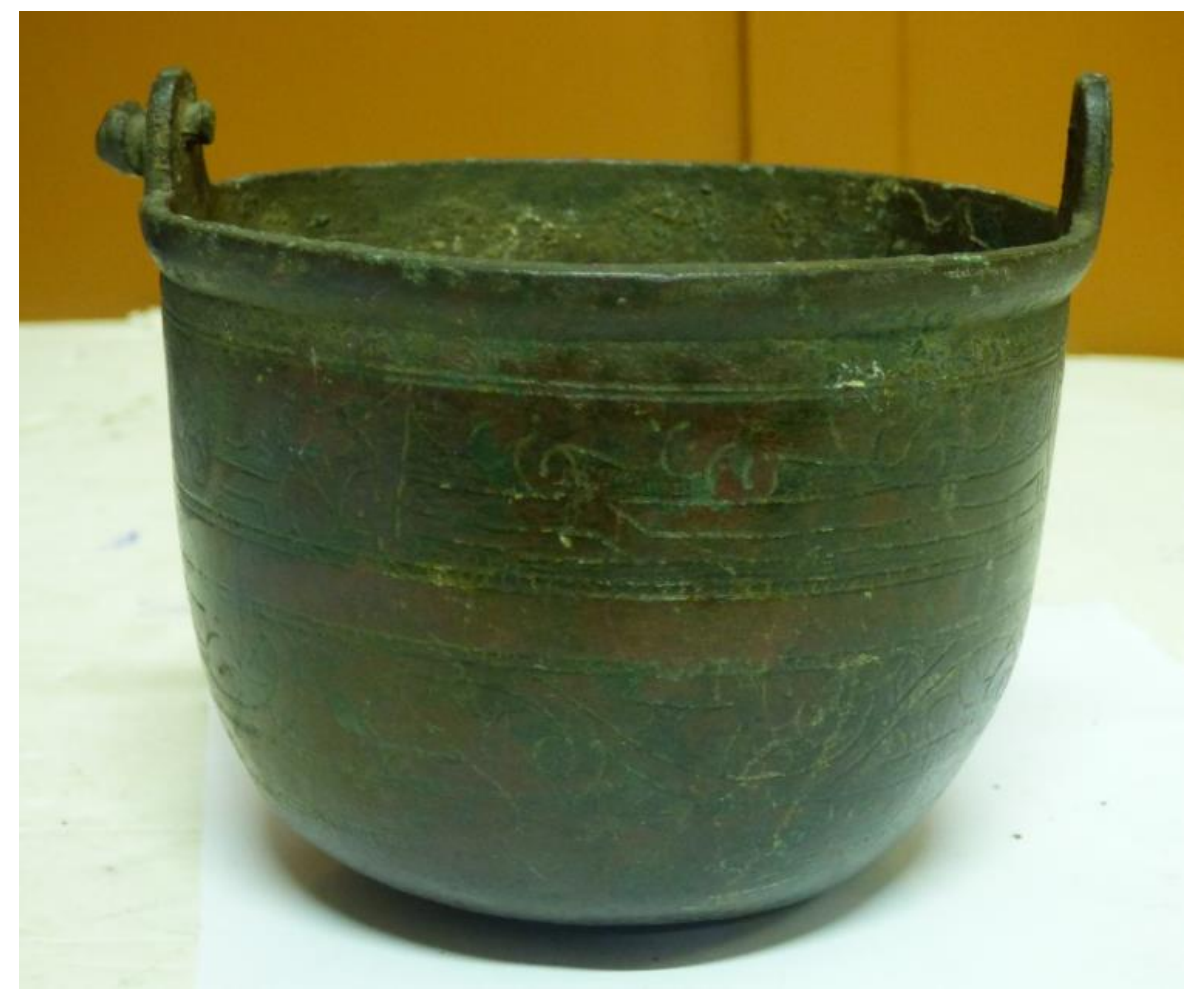

(لوحة 7 ( ) منظر آخر، للالو البرونزي، رقم (9 . (10 )، بمتحف الفن الإسلامي بالقاهرة،

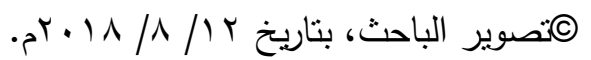

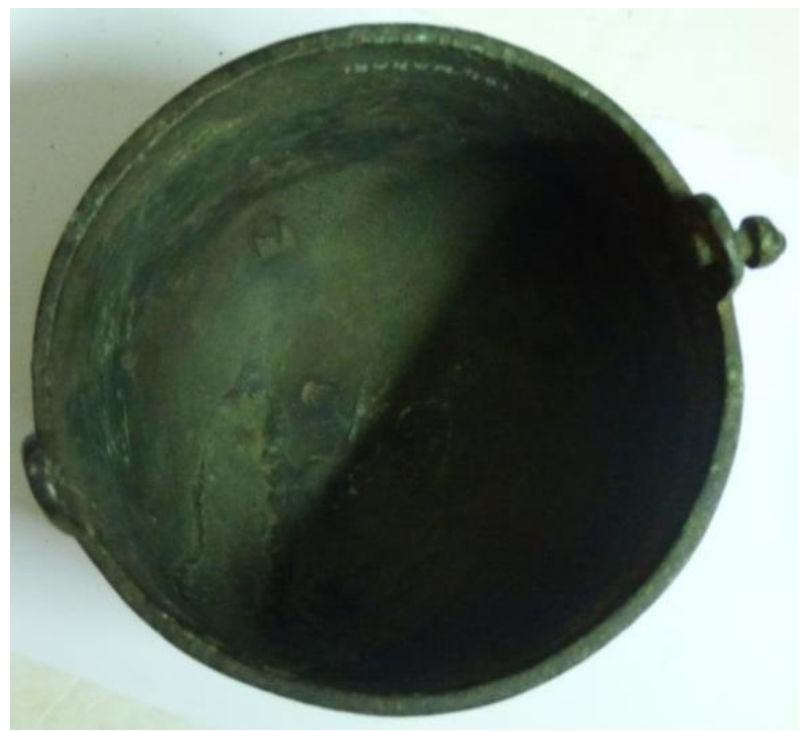

(لوحة 1 1 ): منظر علوي، للالو البرونزي، رقم

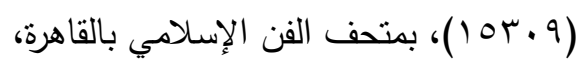

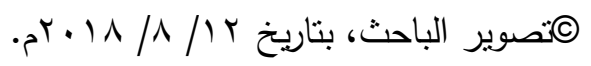

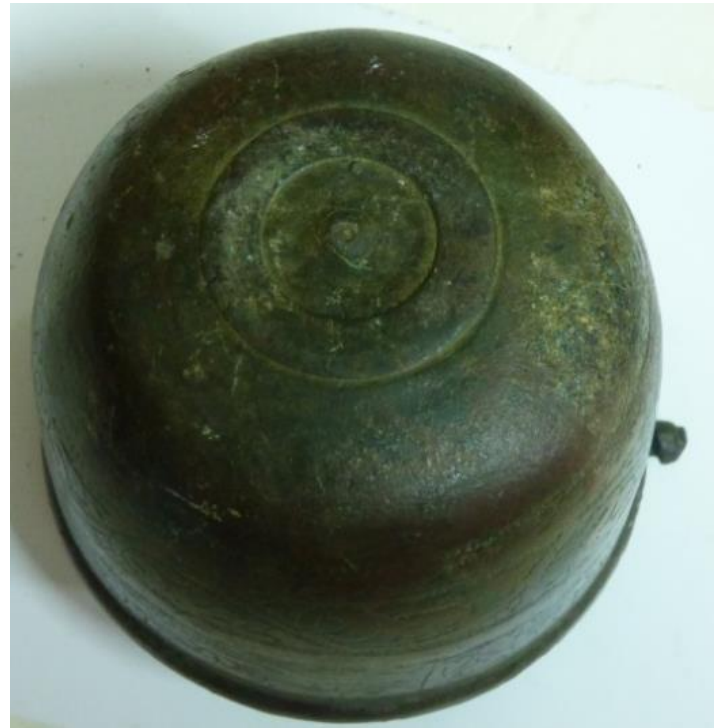

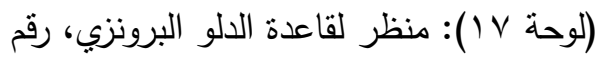

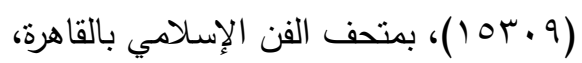

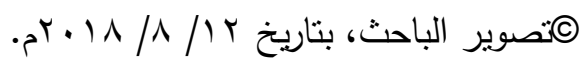




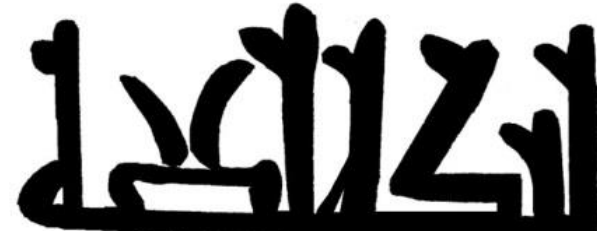

(ب)

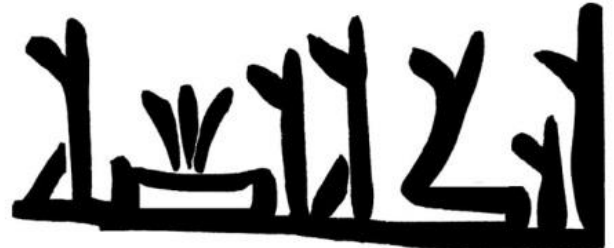

(I)

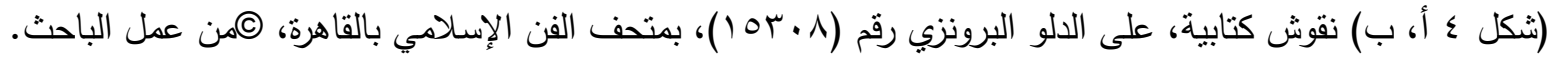

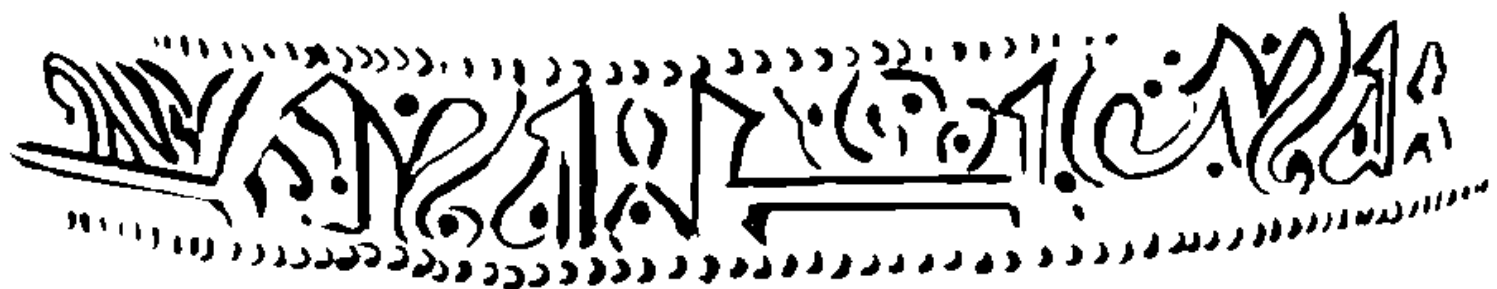

(شكل ه) نقوش كتابية، على الدلو البرونزي رقم (1 • (10 )، بمتحف الفن الإسلامي بالقاهرة، @من عمل الباحث.

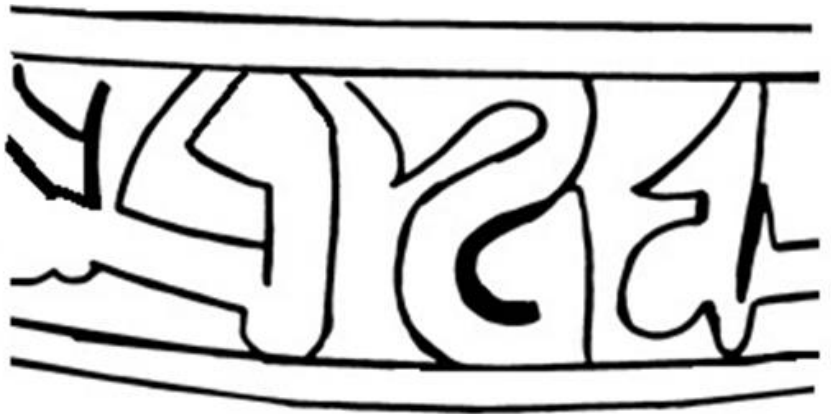

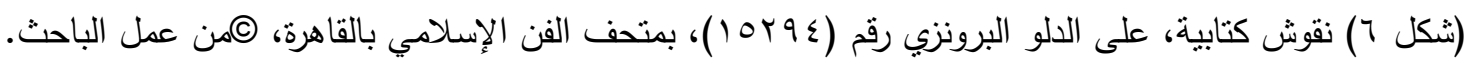

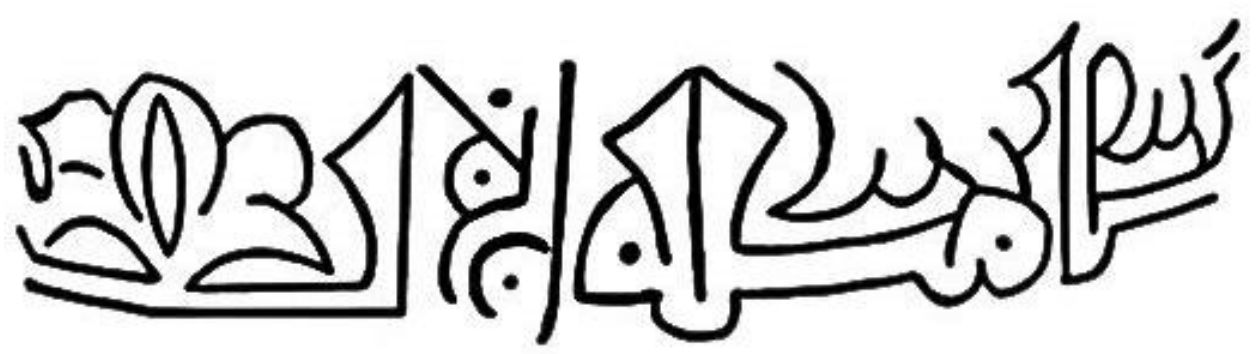

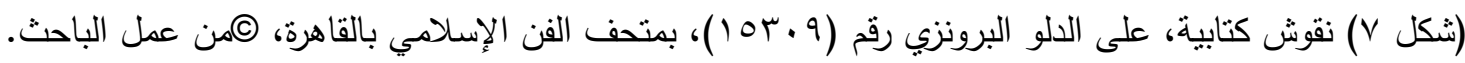




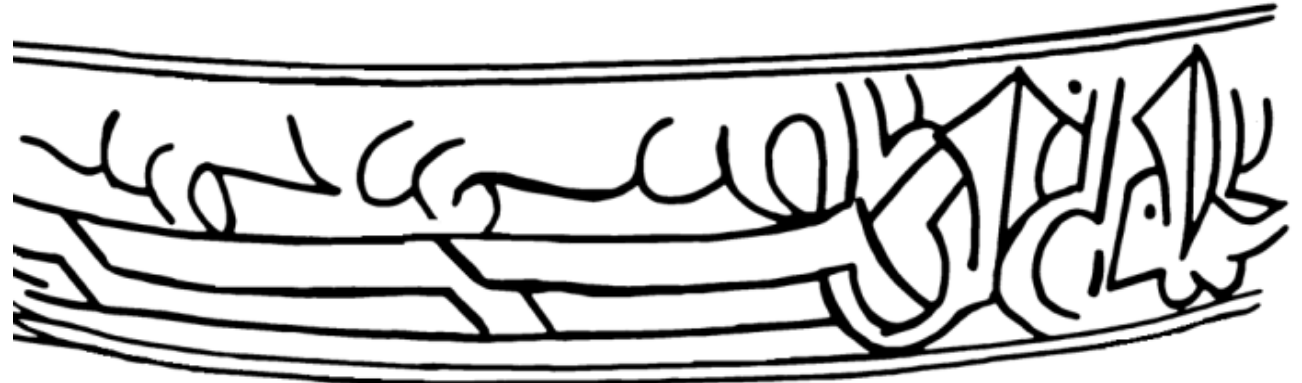

(شكل ^) نقوش كتابية، على الدلو البرونزي رقم (9 . (10 )، بمتحف الفن الإسلامي بالقاهرة، @من عمل الباحث.

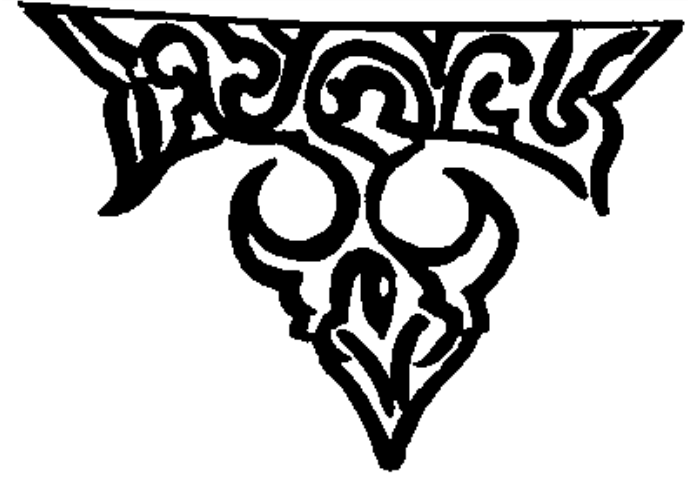

(ب)

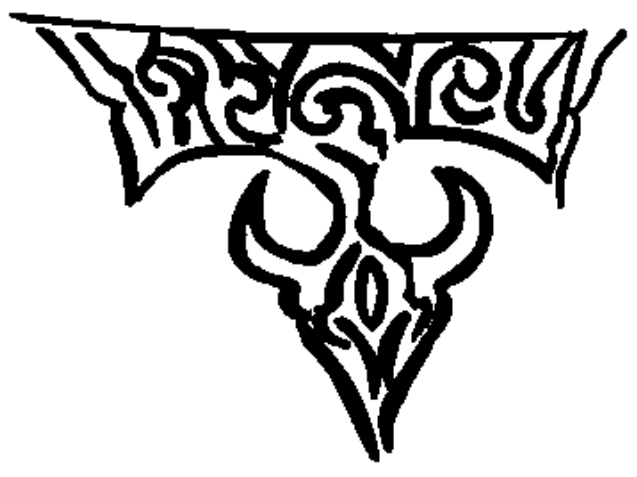

(I)

(شكل 9 أ، ب) زخارف نباتية، على الدلو البرونزي رقم (1 • r 1 )، بمتحف الفن الإسلامي بالقاهرة، @من عمل الباحث.

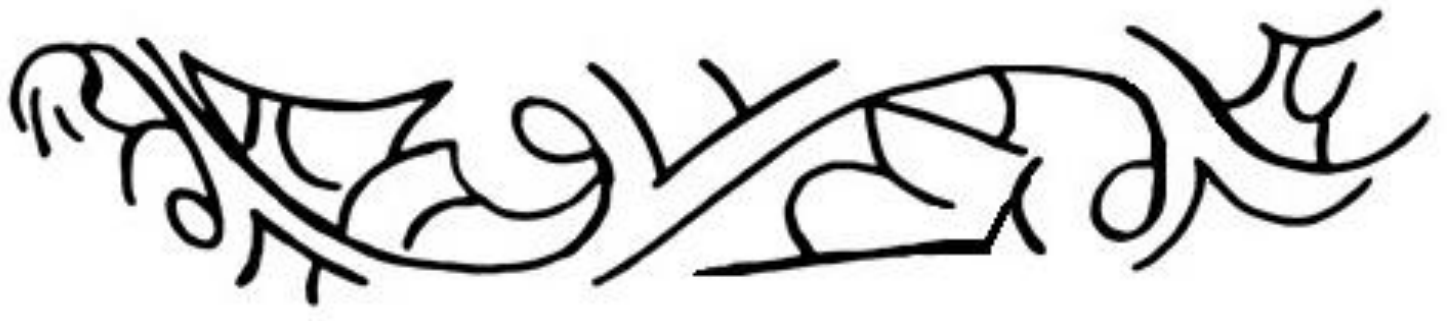

(شكل • (1) زخارف نباتية، على الدلو البرونزي رقم (9 ـ ب 1 )، بمتحف الفن الإسلامي بالقاهرة، (من عمل الباحث. 


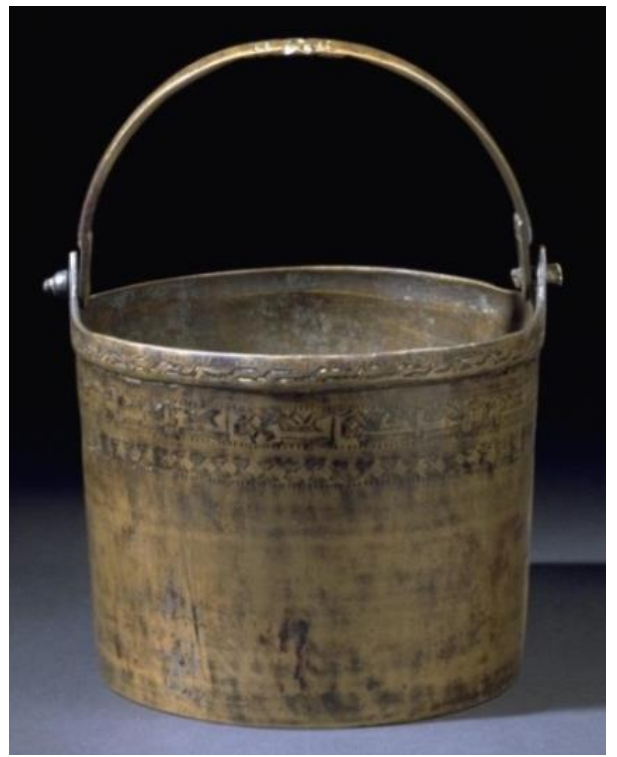

(لوحة • r) دلو من البرونز ، من صناعة مصر ، (لمر ) في العصر الفاطمي، القرن (0ه/ ا (م)، محفوظ M.25- بمتحف فيكتوريا وألبرت بلندن، رقم السجل ،1923

http://media.vam.ac.uk/collections/img/2006/ AT/2006AT3744_2500.jpg (Accessed October $10,2020)$.

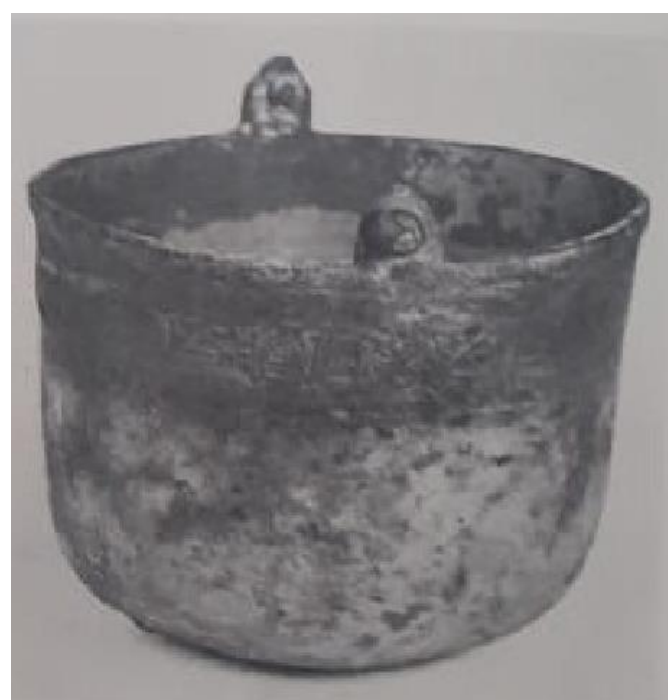

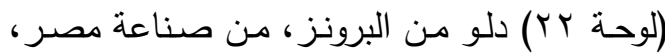
فـي العصـر الفـاطمي، القـرنين (ع- هـــ/ · 1ا (م)، محفوظ بمجموعة كير ، رقم السجل (Yo)، FEHÉRVÁRI, G.: Islamic Metalwork of the Eighth to the Fifteenth Century in the Keir Collection, $1^{\text {st }}$ ed., London: Faber and Faber Limited, 1976, pl. 8c.

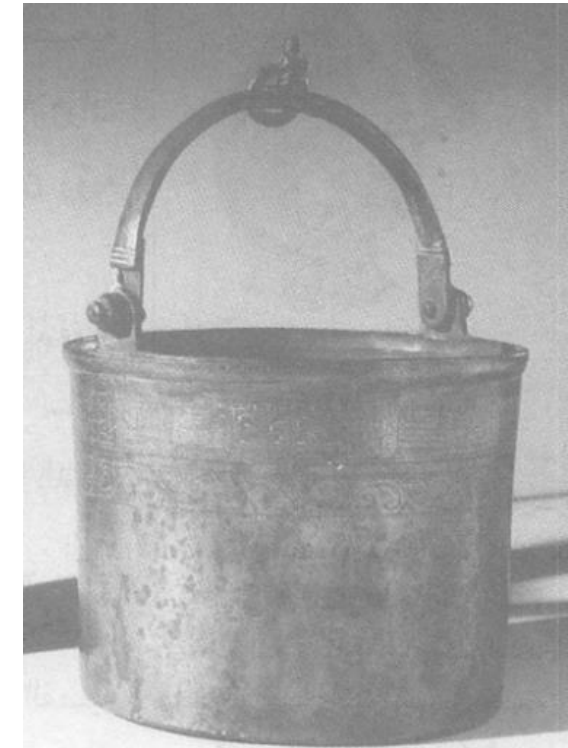

(لوحة 9 ( ) دلو من البرونز ، من صناعة مصر ،

في العصر الفاطمي، القرنين (ع- هـ/ • 1-

ا (م)، محفوظ بمجموعة كير ، رقم السجل (ع ب)، عن: وارد، راشيل، الأعمال الدعدنبة الإسالكية، ترجمة: ليديا البريدي، ط. (، دمشق: دار الكتاب

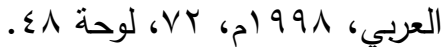

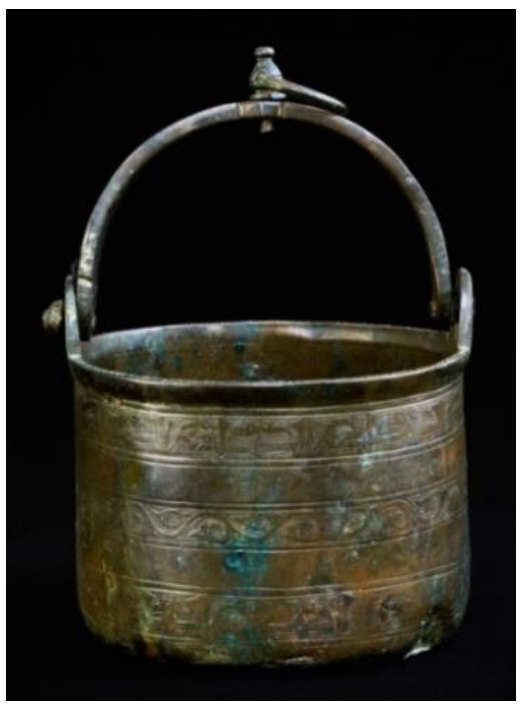

$$
\text { (لوحة (Y) دلو من البرونز ، من صناعة }
$$
مصر ، في العصر الفاطمي، القرنين (ع- مهـ/ • 1 - (م)، محفوظ بمتحف ديفيد،بكوبنهاجن،

$$
\text { بالدنمارك، رقم السجل (87/2003)، }
$$

https://www.davidmus.dk/en/collections/isl amic/dynasties/tulunids-and-

fatimids/art/87-2003 (Accessed October 17, 2020). 